\title{
NBSIR 73-207
}

A孔〕】03 99509己

\section{Chemical Kinetics Data Survey}

\section{VI: Photochemical and Rate Data for}

Twelve Gas Phase Reactions of

\section{Interest for Atmospheric Chemistry}

\author{
R. F. Hampson, Editor \\ D. Garvin, J. T. Herron, R. E. Huie, M. J. Kurylo, \\ A. H. Laufer, H. Okabe, M. D. Scheer, and W. Tsang
}

Physical Chemistry Division

Institute for Materials Research

National Bureau of Standards

Washington, D. C. 20234

\section{August 1973}

Interim Report

$\mathrm{QC}$

100

. $\mathrm{u} 56$

no.73207

\section{sared for}

latic Impact Assessment Program, Department of Transportation,

al Ordnance Systems Command, ORD 3311. Department of the Navy se of Standard Reference Data, N.B.S.,

sures for Air Quality, N.B.S. 

NBSIR 73-207

\section{CHEMICAL KINETICS DATA SURVEY}

VI. PHOTOCHEMICAL AND RATE DATA FOR

TWELVE GAS PHASE REACTIONS OF

\section{INTEREST FOR ATMOSPHERIC CHEMISTRY}

R. F. Hampson, Editor

D. Garvin, J. T. Herron, R. E. Huie, M. J. Kurylo,

A. H. Laufer, H. Okabe, M. D. Scheer, and W. Tsang

Physical Chemistry Division

Institute for Materials Research

National Bureau of Standards

Washington, D. C. 20234

August 1973

Interim Report

Prepared for

Climatic Impact Assessment Program, Department of Transportation, Naval Ordnance Systems Command, ORD 3311, Department of the Navy Office of Standard Reference Data, N.B.S.,

and

Measures for Air Quality, N.B.S.

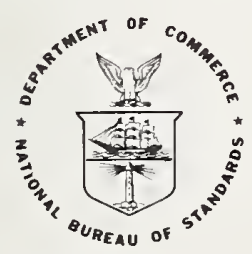

U. S. DEPARTMENT OF COMMERCE, Frederick B. Dent, Secretary 

Abstract

-Introduction (Includes revisions of recommendations in previous

Data Sheets

$$
\begin{aligned}
& \mathrm{H}+\mathrm{H}_{2} \mathrm{O}_{2} \rightarrow \text { Products } \\
& \mathrm{HNO}_{2}+\mathrm{h \nu} \\
& \mathrm{HO}+\mathrm{H}_{2} \mathrm{O}_{2} \rightarrow \mathrm{HO}_{2}+\mathrm{H}_{2} \mathrm{O} \\
& \mathrm{HO}+\mathrm{NO}+\mathrm{M} \rightarrow \mathrm{HNO}_{2}+\mathrm{M} \\
& \mathrm{HO}+\mathrm{NO}_{2}+\mathrm{M} \rightarrow \mathrm{HNO}_{3}+\mathrm{M} \\
& \mathrm{NO}+\mathrm{h \nu} . \\
& \mathrm{NO}+\mathrm{O}+\mathrm{M} \rightarrow \mathrm{NO}_{2}+\mathrm{M} \\
& \mathrm{NO}_{2}+\mathrm{h \nu} \\
& \mathrm{NO}_{2}+\mathrm{O} \rightarrow \mathrm{NO}^{2} \mathrm{O}_{2} \\
& \mathrm{NO}_{2}+\mathrm{O}+\mathrm{M} \rightarrow \mathrm{NO}_{3}+\mathrm{M} \\
& \mathrm{N}_{2} \mathrm{O}_{5}+\mathrm{h \nu} \\
& \mathrm{O}_{2}+\mathrm{h \nu}
\end{aligned}
$$

R. F. Hampson

M. J. Kurylo

W. Tsang

W. Tsang

H. Okabe, R. F. Hampson,

R. E. Huie, J. T. Herron

R. F. Hampson, D. Garvin

R. E. Huie, J. T. Herron

R. E. Huie, J. T. Herron

A. H. Laufer

Appendix A. Reactions of Potential Interest for the Chemistry of the Stratosphere.

Appendix B. Conversion Tables: Rate Constants, Energy Units and Optical Absorption Coefficients.

Appendix C. Errata to NBSIR 73-203 and NBSIR 73-206. 

VI. Photochemical and Rate Data for Twelve Gas Phase

Reactions of Interest for Atmospheric Chemistry

\section{Abstract}

Photochemical and rate data have been evaluated for twelve gas phase reactions of interest for the chemistry of the stratosphere. The results are presented in data sheets, one for each reaction. For each reaction the data are summarized. A preferred value is given for the rate constant or the primary quantum yield and photoabsorption cross section.

Key words: atmospheric chemistry; chemical kinetics; data evaluation; gas phase reaction; optical absorption cross section; photochemistry; quantum yield; rate constants.

\section{Introduction}

This report presents evaluations of chemical kinetic and photochemical data for twelve gas phase reactions. It is the sixth in a series. The objective of the work and a description of the general format of a data sheet including explanatory material regarding general conventions for the presentation of data have been given in the introductory sections of two previous reports: NBS Report 10692 (January 1972) and NBS Report 10828 (Apri1 1972).

The evaluations in these two reports have been updated recently and will be published in "Survey of Photochemical and Rate Data for TwentyEight Reactions of Interest in Atmospheric Chemistry", R. F. Hampson, editor. J. Phys. Chem. Ref. Data 2, 非(1973). For some reactions, a change was made in the recommended value of the rate constant, quantum yield or absorption cross section. These changes are summarized in the following tables. 
Table 1. Revised Recommended Values for Reactions Evaluated in NBS Reports 10692 and 10828

RATE CONSTANTS

\begin{tabular}{|c|c|c|c|}
\hline Reaction & $\mathrm{k} / \mathrm{cm}^{3}$ molecule $\mathrm{e}^{-1} \mathrm{~s}^{-1}$ & $\mathrm{~T} / \mathrm{K}$ & $\Delta \log k$ \\
\hline $\mathrm{H}+\mathrm{HNO} \rightarrow \mathrm{H}_{2}+\mathrm{NO}$ & $7 \times 10^{-12}$ & 2000 & \pm 0.3 \\
\hline $\mathrm{HNO}+\mathrm{HO} \rightarrow \mathrm{H}_{2} \mathrm{O}+\mathrm{NO}$ & $7 \times 10^{-11}$ & $1600-2100$ & \pm 0.7 \\
\hline $\mathrm{HNO}_{2}+\mathrm{HO} \rightarrow \mathrm{H}_{2} \mathrm{O}+\mathrm{NO}_{2}$ & No recommendation & & \\
\hline $\mathrm{HNO}_{3}+\mathrm{HO} \rightarrow \mathrm{H}_{2} \mathrm{O}+\mathrm{NO}_{3}$ & $6 \times 10^{-13} \exp (-400 / \mathrm{T})$ & $300-650$ & \pm 0.5 \\
\hline $\mathrm{HO}+\mathrm{O}_{3} \rightarrow \mathrm{HO}_{2}+\mathrm{O}_{2}$ & $1.6 \times 10^{-12} \exp (-1000 / \mathrm{T})$ & $220-450$ & \pm 0.3 \\
\hline $\mathrm{HO}_{2}+\mathrm{HO}_{2} \rightarrow \mathrm{H}_{2} \mathrm{O}_{2}+\mathrm{O}_{2}$ & $3 \times 10^{-11} \exp (-500 / \mathrm{T})(\mathrm{a})$ & $300-1000$ & $\pm 0.3(\mathrm{~b}$ \\
\hline $\mathrm{H}_{2} \mathrm{O}+\mathrm{NO}+\mathrm{NO}_{2} \rightarrow 2 \mathrm{HNO}_{2}$ & $<1.1 \times 10^{-55}$ (c) & 300 & \\
\hline $\mathrm{H}_{2} \mathrm{O}+\mathrm{N}_{2} \mathrm{O}_{5} \rightarrow 2 \mathrm{HNO}_{3}$ & $<1 \times 10^{-20}$ & 300 & \\
\hline $\mathrm{H}_{2} \mathrm{O}+\mathrm{O}\left({ }^{1} \mathrm{D}\right) \rightarrow 2 \mathrm{HO}$ & $3.5 \times 10^{-10}$ & 300 & \pm 0.1 \\
\hline $\mathrm{H}_{2} \mathrm{O}_{2}+\mathrm{NO} \rightarrow \mathrm{HO}+\mathrm{HNO}_{2}$ & $\sim 5 \times 10^{-20}$ & 300 & \\
\hline $\mathrm{NO}_{2}+\mathrm{O}_{3} \rightarrow \mathrm{NO}_{3}+\mathrm{O}_{2}$ & $5 \times 10^{-17}$ & 298 & \pm 0.2 \\
\hline $\mathrm{N}_{2} \mathrm{O}+\mathrm{O}\left({ }^{1} \mathrm{D}\right) \rightarrow \mathrm{N}_{2}+\mathrm{O}_{2}$ & $1.1 \times 10^{-10}$ & 300 & \pm 0.1 \\
\hline$\rightarrow 2 \mathrm{NO}$ & $1.1 \times 10^{-10}$ & 300 & \pm 0.1 \\
\hline $\mathrm{O}+\mathrm{O}_{3} \rightarrow 2 \mathrm{O}_{2}$ & $1.9 \times 10^{-11} \exp (-2300 / \mathrm{T})$ & $200-1000$ & \pm 0.1 \\
\hline $\mathrm{O}_{2}\left({ }^{1} \Delta\right)+\mathrm{M} \rightarrow \mathrm{O}_{2}+\mathrm{M}$ & $<2 \times 10^{-20}\left(\mathrm{M}=\mathrm{N}_{2}\right)$ & 300 & \\
\hline
\end{tabular}

(a) $-\mathrm{d}\left[\mathrm{HO}_{2}\right] / \mathrm{dt}=2 \mathrm{k}\left[\mathrm{HO}_{2}\right]^{2}$

(b) Uncertainty in $\log \mathrm{k}$ increases to \pm 1 at $1000 \mathrm{~K}$.

(c) $-\mathrm{d}\left[\mathrm{NO}_{2}\right] / \mathrm{dt}=\mathrm{k}[\mathrm{NO}]\left[\mathrm{NO}_{2}\right]\left[\mathrm{H}_{2} \mathrm{O}\right]^{2}$. The experimental data show a second order dependence of rate on $\left[\mathrm{H}_{2} \mathrm{O}\right]$. Value for $k$ is for a surface reaction. This is adopted as the upper limit for the gas phase rate constant. 


\section{PHOTOCHEMICAL DATA}

\begin{tabular}{|c|c|c|}
\hline $\begin{aligned} \frac{\text { Reaction }}{\mathrm{HNO}_{3}+\mathrm{h \nu}} & \rightarrow \mathrm{HO}+\mathrm{NO}_{2} \\
\mathrm{O}_{3}+\mathrm{h \nu}(\mathrm{uv}) & \rightarrow \mathrm{O}\left({ }^{1} \mathrm{D}\right)+\mathrm{O}_{2}\left({ }^{3} \Sigma_{\mathrm{g}}^{-}\right) \\
& \rightarrow \mathrm{O}\left({ }^{3} \mathrm{P}\right)+\mathrm{O}_{2} \text { (singlet) } \\
& \rightarrow O\left({ }^{1} \mathrm{D}\right)+\mathrm{O}_{2}\left({ }^{1} \triangle\right)\end{aligned}$ & $\begin{array}{c}\text { Quantum yield, } \phi(\lambda) \\
\text { no recommendation } \\
0 \\
\sim 1 \\
0 \\
1 \\
0\end{array}$ & $\begin{array}{r}<350 \\
310-350 \\
<310 \\
250-310 \\
>310\end{array}$ \\
\hline
\end{tabular}

Also, the newer values of the absorption cross section for nitric acid by Johnston and Graham (J. Phys. Chem. 77, 62 (1973)) are now the recommended values.

\section{Note concerning the $\mathrm{O}_{3}$ quantum yields}

The behavior of $\emptyset\left(O^{1} \mathrm{D}\right)$ near $\lambda=310 \mathrm{~nm}$ is currently under study in several laboratories. These should provide a better definition of $\emptyset\left(O\left({ }^{1} D\right)\right.$ in the critical region near the thermochemical threshold. A reanalysis of the matter will appear in a later publication in this series. 
The Reaction of $\mathrm{H}$ with $\mathrm{H}_{2} \mathrm{O}_{2}$

1. Two channels are possible for this reaction; they are

$$
\begin{aligned}
& \mathrm{H}+\mathrm{H}_{2} \mathrm{O}_{2} \rightarrow \mathrm{H}_{2}+\mathrm{HO}_{2} \\
& \mathrm{H}+\mathrm{H}_{2} \mathrm{O}_{2} \rightarrow \mathrm{H}_{2} \mathrm{O}+\mathrm{HO}^{2}
\end{aligned}
$$

2. $\Delta \mathrm{H}_{298}^{\circ}(1)=-61 \pm 8 \mathrm{~kJ} / \mathrm{mol}(-14.5 \pm 2 \mathrm{kcal} / \mathrm{mol})$

$$
\Delta \mathrm{H}_{298}^{\circ}(2)=-284 \mathrm{~kJ} / \mathrm{mol}(-68.0 \mathrm{kcal} / \mathrm{mo} 1)
$$

$$
\begin{aligned}
& \log _{10} \mathrm{~K}_{\text {eq. }}(1)=0.342+3.26(1000 / \mathrm{T}) \\
& \log _{10} \mathrm{~K}_{\text {eq. }}(2)=0.877+14.98(1000 / \mathrm{T})
\end{aligned}
$$

\section{Data}

The available rate data have been presented and evaluated by Baulch, Drysdale, Horne and Lloyd (c). In their 1972 review, they recommended the expression $k_{1}=2.8 \times 10^{-12} \exp (-1900 / \mathrm{T}) \mathrm{cm}^{3}$ molecule ${ }^{-1} \mathrm{~s}^{-1}$ from 300 to $800 \mathrm{~K}$ and made no recommendation for $\mathrm{k}_{2}$. There have been no more recent measurements.

Albers et al (d) measured the total rate of removal of $D$ atoms in a discharge-flow reactor from 294 to $464 \mathrm{~K}$ with 5-8 torr $\mathrm{H}_{2} \mathrm{O}_{2}$ and added 0 atoms to suppress the chain decomposition initiated by $\mathrm{OH}$. D atoms were monitored by ESR and mass spectrometry. They estimate that $k_{1} / k_{2} \approx 10$ for $D$ atoms at $421 \mathrm{k}$. Also they find $k_{1}{ }^{(H)} / k_{1}{ }^{(D)}=0.43$ at $375 \mathrm{~K}$. They give the result that $k_{1}{ }^{(D)}+k_{2}{ }^{(D)}=1.2 \times 10^{-11}$ exp $(-4200 / \mathrm{RT}) \mathrm{cm}^{3}$ molecule $\mathrm{s}^{-1} \cdot(294-464 \mathrm{~K})$.

Baldwin et al (e) studied the decomposition of $\mathrm{H}_{2} \mathrm{O}_{2}$ in the presence of $\mathrm{H}_{2}$ from $713-773 \mathrm{~K}$. They report $\mathrm{k}_{1} / \mathrm{k}_{2}$ to have the value 0.143 over this temperature range (note: in their abstract this is incorrectly given as 0.125$)$. Also they measure the ratio $k_{2} / k_{3}$ where (3) is $\mathrm{H}+\mathrm{O}_{2}+\mathrm{M} \rightarrow \mathrm{HO}_{2}+\mathrm{M}$. From this ratio and their previously measured values of $\mathrm{k}_{3} / \mathrm{k}_{4}$ where (4) is $\mathrm{H}+\mathrm{O}_{2} \rightarrow \mathrm{HO}+0$ they derive 
values of $k_{2} / k_{4}$. Baulch et al (c) use the values $k_{1} / k_{2}$ and $k_{2} / k_{4}$ in (e) with their own recommended expression for $k_{4}$ to obtain values of $k_{1}$. (Note: Because Baulch et al used the value of $k_{1} / k_{2}$ in Baldwin's abstract, the calculated values of $k_{1}$ given on $p \cdot 212$ of (c) should be increased by $14 \%$; however this will not seriously affect their evaluation).

4. Preferred value

$k_{1}=2.8 \times 10^{-12} \exp (-1900 / \mathrm{T}) \mathrm{cm}^{3}$ molecule ${ }^{-1} \mathrm{~s}^{-1}(300-800 \mathrm{~K})$ uncertainty: factor of two no value is recommended for $k_{2}$

\section{5. $\quad \underline{\text { Remarks }}$}

The recommendations of Baulch et al have been adopted. The value derived there for $k_{2}=3.7 \times 10^{-9} \exp (-5900 / \mathrm{T}) \mathrm{cm}^{3}$ molecule $\mathrm{e}_{\mathrm{s}}^{-1}$ as noted there can not be recommended with any confidence because of the unreasonably high value of the pre-exponential factor. By extrapolation, $k_{1}$ at stratospheric temperatures $(220 \mathrm{~K}$ ) is estimated to be $5 \times 10^{-16} \mathrm{~cm}^{3}$ molecule $\mathrm{s}^{-1}$. From these expressions $k_{2} / k_{1}$ at $220 \mathrm{~K}$ is estimated to be $10^{-5}$, subject to a large uncertainty.

\section{$\underline{\text { References }}$}

a) D. D. Wagman et a1, NBS Technical Note 270-3 (Jan. 1968).

b) V. N. Kondratiev, "Rate Constants of Gas Phase Reactions Reference Book," R. M. Fristrom, editor. National Technical Information Service, Springfield, Virginia COM-72-10014 (Jan. 1972). 
c)
D. L. Baulch,
D.
D. Drysdale, D. G. Horne, A
C. Lloyd,

"Evaluated Kinetic Data for High Temperature Reactions

volume 1 , Homogeneous gas phase reactions of the $\mathrm{H}_{2}-\mathrm{O}_{2}$

systems," Butterworth \& Co. London (1972).

d) E. A. Albers, K. Hoyermann, G. Gg. Wagner, J. Wolfrum, 13 th Combustion Symposium 81 (1971).

e)

R. R. Baldwin, D. Brattan, B. Tunnicliffe, R. W. Walker,

S. J. Webster, Combustion and Flame 15, 133 (1970).

M. D. Scheer

September, 1972 
PHOTOCHEMISTRY OF $\mathrm{HNO}_{2}$

1. Primary Photochemical Transitions

$\underline{\text { Reaction }}$

$\frac{\Delta H 8}{\underline{\mathrm{kJ} / \mathrm{mo} 1} \quad \underline{\mathrm{kca} 1 / \mathrm{mol}}}$

$\mathrm{HNO}_{2} \rightarrow \mathrm{OH}+\mathrm{NO}$

$\rightarrow \mathrm{H}+\mathrm{NO}_{2}$

$\rightarrow \mathrm{HNO}+0$
202

326

423 $\lambda$ threshold (nm)

$\left(\triangle H_{0}^{O}\right.$ values from [a] except $\Delta_{O}^{O}$ (HNO) from [b])

\section{Data}

The absorption spectrum of $\mathrm{HNO}_{2}$ vapor in the region $300-400 \mathrm{~nm}$, has been reported and partly analyzed ( $\operatorname{ref}[c]$ and references cited therein ). It consists of a series of diffuse absorption bands which showed no fine structure when photographed on a 20-foot grating spectrograph with a resolving power of 150,000 . Fig. 1 (from [c]) shows the absorption spectrum of $\mathrm{HNO}_{2}$ at $25^{\circ} \mathrm{C}$.

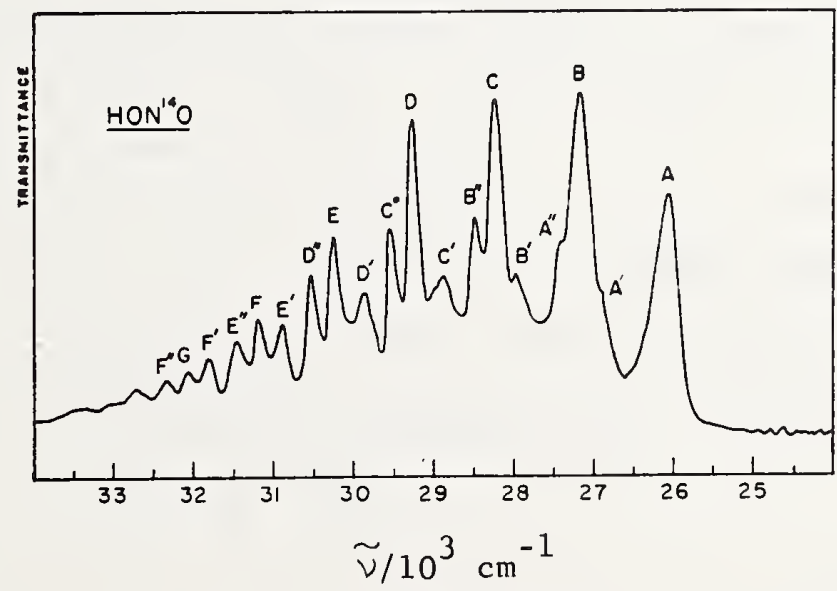

Fig. 1 The absorption spectrum of HONO at $25 \mathrm{C}$.

Reproduced by permission of the National Research Council of Canada from the Canadian Journal of Chemistry, 40, 2057-2065 (1962) 
No absorption coefficients nor quantum yields have been published. Preliminary measurements (H. Johnston, private communication) on $\mathrm{NO}+\mathrm{NO}_{2}+\mathrm{H}_{2} \mathrm{O} \rightleftarrows 2 \mathrm{HNO}_{2}$ equilibrium mixtures provide a scale for figure 1, good to a factor of 1.5 to 2 . The absorption cross sections for peaks $\mathrm{B}$ and $\mathrm{E}$, averaged over a $1 \mathrm{~nm}$ wavelength interva 1 were $10.7 \times 10^{-20}$ and $3.8 \times 10^{-20} \mathrm{~cm}^{2}$ molecule ${ }^{-1}$ respectively. The only related data on absorption coefficients are for $\mathrm{HNO}_{2}$ in aqueous solution $[\mathrm{d}]$. For $\mathrm{HNO}_{2}$ in 0.05 normal $\mathrm{HCl}$, there are a series of bands from 380 to $320 \mathrm{~nm}$, with the maximum value of the decadic molar extinction coefficient equal to 501 iter mol $\mathrm{cm}^{-1}$ at approxinately 371 and $358 \mathrm{~nm}$. (abs. cross section $=1.9 \times 10^{-19}$ $\mathrm{cm}^{2}$ ). These values obtained in a polar solvent are not recommended for use in calculating the absorption of $\mathrm{HNO}_{2}$ in the gas phase.

3. $\quad$ Preferred values

No values are recommended for the absorption coefficient or the quantum yield.

\section{References}

[a] D. D. Wagman et a1, NBS Technical Note 270-3 (Jan. 1968).

[b] D. R. Stull and H. Prophet, "JANAF Thermochemical Tables, 2d. Ed." Nat. Stand. Ref. Data Ser., Nat. Bur. Stand. (U.S.), 37 (June, 1971).

[c] G. W. King and D. Moule, Can. J. Chem. 40, 2057 (1962).

[d] G. Kortüm, Z. Phys. Chem. B43, 418 (1939). 
The Reaction of $\mathrm{HO}$ with $\mathrm{H}_{2} \mathrm{O}_{2}$

1. Reaction

$\mathrm{HO}+\mathrm{H}_{2} \mathrm{O}_{2} \rightarrow \mathrm{HO}_{2}+\mathrm{H}_{2} \mathrm{O}$.

2. $\Delta \mathrm{H}^{\circ}(298)=-124.3 \mathrm{~kJ} \mathrm{~mol}^{-1}\left(-29.7 \mathrm{kcal} \mathrm{mol} \mathrm{mol}^{-1}\right)$

$\log _{10} \mathrm{~K}_{\mathrm{eq}}=-0.329+6.612(1000 / \mathrm{T})$

3. Data

a. The available data prior to 1972 have been described and evaluated by Baulch et al [h] and by Drysdale and Lloyd [i]. In these reviews in 1972 and 1970, they recommended the expression $\mathrm{k}_{1}=$ $1.7 \times 10^{-11} \exp (-910 / \mathrm{T}) \mathrm{cm}^{3}$ molecule $\mathrm{s}^{-1}$ from 300 to $800 \mathrm{~K}$.

Upper and lower limits for $k_{1}$ at $298 \mathrm{~K}$ have been derived from studies employing flash photolysis [b] and electric discharge [c] of $\mathrm{H}_{2} \mathrm{O}_{2}$.

Absolute values of $k_{1}$ over the temperature range $307-462 \mathrm{~K}$ have been determined in flash photolysis studies by following the $\mathrm{OH}$ decay by kinetic spectroscopy.

Rate ratio data at higher temperatures extends the range. A $\mathrm{k}_{1} / \mathrm{k}_{2}$ ratio was determined at $798 \mathrm{~K}$ using the thermal decomposition of $\mathrm{H}_{2} \mathrm{O}_{2}$ in the presence $\mathrm{CO}$ [d].

$$
\mathrm{CO}+\mathrm{HO} \rightarrow \mathrm{CO}_{2}+\mathrm{H}
$$


$\mathrm{HO}+\mathrm{H}_{2} \mathrm{O}_{2}$

The rate relative to reaction 3 ,

$$
\mathrm{HO}+\mathrm{H}_{2} \rightarrow \mathrm{H}+\mathrm{H}_{2} \mathrm{O}
$$

has been determined between 700 and $800 \mathrm{~K}$ by examination of

the inhibition of the second explosion limit of the $\mathrm{H}_{2} / \mathrm{O}_{2}$ system by $\mathrm{H}_{2} \mathrm{O}_{2}$ [e], in studies of the decomposition of $\mathrm{H}_{2} \mathrm{O}_{2}$ in the presence of $\mathrm{H}_{2}$ in boric acid coated vessels [f] and from studies of the $\mathrm{H}_{2} / \mathrm{O}_{2} / \mathrm{N}_{2}$ system $[\mathrm{g}]$.

\section{b. Recent measurements}

There has been only one measurement involving the rate of this reaction since the 1972 review by Baulch et al (h).

\section{Quantity Measured}

$\mathrm{k}_{1} / \mathrm{k}_{2}=8.13 \pm 0.56$

where $\mathrm{k}_{2}: \mathrm{HO}+\mathrm{CO} \rightarrow \mathrm{CO}_{2}+\mathrm{H}$

\section{System}

Photolysis of $\mathrm{H}_{2} \mathrm{O}_{2}$ (0.94 torr)

at $254 \mathrm{~nm}$. in presence of $\mathrm{O}_{2}$

(5.4 tor $r)$ and $\mathrm{CO}(3-32$ tor $r)$.

Measured initial rate of formation of $\mathrm{CO}_{2}$.

GORSE, VOLMAN 1972 (k)

4. Preferred Value

$\mathrm{k}_{1}=1.7 \times 10^{-11} \exp (-910 / \mathrm{T}) \mathrm{cm}^{3}$ molecule $\mathrm{s}^{-1}$ for $300<\mathrm{T}<800$.

$k_{1}(300 \mathrm{~K})=8.2 \times 10^{-13} \mathrm{~cm}^{3}$ molecule $\mathrm{s}^{-1}$. This is the evaluation given in refs $[h, i]$. It fits the measured data within $50 \%$ 。 


\section{5. $\quad \underline{\text { Remarks }}$}

$$
\mathrm{HO}+\mathrm{H}_{2} \mathrm{O}_{2}
$$

Reaction 1 is a simple $\mathrm{H}$ atom abstraction

$$
\mathrm{HO}+\mathrm{H}-\mathrm{O}_{2} \mathrm{H} \rightarrow \mathrm{H}_{2} \mathrm{O}+\mathrm{HO}_{2}
$$

and is the only interaction expected in this system.

The evaluation relies heavily on the data of Greiner which are the only absolute rate measurements available. The flash photolysis study is subject to some uncertainty due to the method of temperature measurement. The temperature was varied by changing inert gas pressures thereby lowering the effect of flash heating. This coupled with the normal experimental uncertainties gives a reliabity factor of approximately 2 to the data. Thus, the expression given above probably predicts the value for $k_{1}$ within a factor of 2 over the temperature range 298 to $800 \mathrm{~K}$. At stratospheric temperatures $200-240 \mathrm{~K}$ the uncertainty is considerably larger (probably at least a factor of 4). Thus a number of lower temperature measurements are in order. 
A value of $k_{1}$ can be derived from the recent relative rate measurement in ref. (k) by selecting a value for $\mathrm{k}_{2}: \mathrm{HO}+\mathrm{CO} \rightarrow$ $\mathrm{CO}_{2}+\mathrm{H}$. For the room temperature value of $\mathrm{k}_{2}$ we select the recent direct measurement of Stuhl and Niki $(l): k_{2}=1.35 \times 10^{-13} \mathrm{~cm}^{3}$ molecule $e^{-1}{ }^{-1}$. This result has been confirmed quite recently in a study using a completely different technique (m). Using this value, we derive the value $k_{1}=(11 \pm 3) \times 10^{-13} \mathrm{~cm}^{3}$ molecule $\mathrm{s}^{-1}$ from the ratio measured in (k). We consider this to be in substantial agreement with the value $k_{1}(300 \mathrm{~K})=8.2 \times 10^{-13} \mathrm{~cm}^{3}$ molecule $\mathrm{s}^{-1}$ recommended in section 4 . The combined uncertainties in the measured values of $\left(k_{1} / k_{2}\right)$ and $k_{2}$ and the complexity of the mechanism used in (k) do not justify changing the recommended value of $k_{1}$. Alternatively, one can use for $k_{2}$ the expression $k_{2}=$ $5.1 \times 10^{-13} \exp (-300 / \mathrm{T}) \mathrm{cm}^{3}$ molecule $\mathrm{s}^{-1}$ recommended by Wilson in his recent lengthy review of hydroxyl radical reaction kinetics ( $n$ ). This expression gives $\mathrm{k}_{2}=1.88 \times 10^{-13} \mathrm{~cm}^{3}$ molecule $\mathrm{e}^{-1}$, which value, when combined with the ratio measured in $(k)$ gives $k_{1}=15 \times 10^{-13}$ $\mathrm{cm}^{3}$ molecule $\mathrm{s}^{-1}$.

\section{$\underline{\text { References }}$}

a) D. R. Stu11 and H. Prophet, "JANAF Thermochemica1 Tables, 2d. Ed." Nat. Stand. Ref. Data Ser., Nat. Bur. Stand. (U.S.), 37 (June 1971).

b) N. R. Greiner, J. Chem. Phys. 45, 99 (1966); ibid, 46, 2450 (1967) (erratum); superseded by J. Phys. Chem. 72, 406 (1968).

c) S. N. Foner and R. L. Hudson, J. Chem. Phys. 36, 2681 (1962).

d) D. E. Hoare, Proc. Roy. Soc. (London) A291, 73 (1966). 
e) W. Forst and P. A. Giguere, J. Phys. Chem. 62 , 340 (1958), R. R.

Baldwin and L. Mayor, Trans. Faraday Soc. 56, 80 and 103 (1960),

R. R. Baldwin, P. Doran and L. Mayor, Symp. Combust 8th, 103 (1962).

f) R. R. Baldwin and D. Brattan, Symp. Combust 8th, 110 (1962), R. R. Baldwin, D. Jackson, R. W. Walker and S. J. Webster, Symp. Combust 10th, 423 (1965).

g) R. R. Baldwin, D. Jackson, R. W. Walker and S. J. Webster, Trans. Faraday Soc. 63, 1676 (1967).

h) D. L. Baulch, D. D. Drysdale, D. G. Horne, A. C. Lloyd, "Evaluated Kinetic Data for High Temperature Reactions volume 1 , Homogeneous gas phase reactions of the $\mathrm{H}_{2}-\mathrm{O}_{2}$ system", Butterworth \& Co., Lond on (1972); a1so in D. L. Baulch, D. D. Drysdale and A. C. Lloyd, High Temperature Reaction Rate Data, Report No. 3 (1969), Dept. of Physical Chemistry, The University, Leeds, England.

i) D. D. Drysdale and A. C. Lloyd, Oxidation and Combustion Reviews, 4, 157 (1970).

j) V. N. Kondratiev, "Rate Constants of Gas Phase Reactions Reference Book," R. M. Fristrom, editor. National Technical Information Service, Springfield, Virginia COM-72-10014 (Jan. 1972). 
k) R. A. Gorse and D. H. Volman, J. Photochem., 1, 1-10 (1972).

l) F. Stuhl and H. Niki, J. Chem. Phys. 57, 3671 (1972).

m) A. A. Westenberg and N. de Haas, J. Chem. Phys. 58, 4061 (1973).

n) W. E. Wilson, Jr., J. Phys. Chem. Ref. Data 1, 535 (1972).

July, 1972

Revised July, 1973

M. J. Kurylo 


\section{Chemical Kinetics Data Survey}

The Combination of HO with NO

1. Reaction evaluated

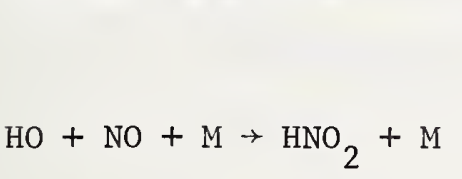

2. Related reactions

$$
\begin{aligned}
& \mathrm{HNO}_{2}+\mathrm{M} \rightarrow \mathrm{HO}+\mathrm{NO}+\mathrm{M} \\
& \mathrm{HO}+\mathrm{CO} \rightarrow \mathrm{CO}_{2}+\mathrm{H} \\
& \mathrm{HO}+\mathrm{H}_{2} \rightarrow \mathrm{H}_{2} \mathrm{O}+\mathrm{H}
\end{aligned}
$$

3. Data

\section{Results}

$\frac{k_{1} \times 10^{31}}{\mathrm{~cm}^{6} \text { molecule }{ }^{-2} \mathrm{~s}^{-1}}$

$$
4 \pm 2
$$

$2.5 \pm 1$

$\frac{k_{1} \times 10^{31}}{\mathrm{~cm}^{6} \text { molecule } \mathrm{s}^{-1}}$

$$
4.1 \pm 0.6
$$

300

$1.9 \pm 0.3$

416

$$
\mathrm{k}_{1}\left(\mathrm{H}_{2}\right) / \mathrm{k}_{1}(\mathrm{He})=2.3 \pm 0.9
$$
5

8

$$
\Delta \mathrm{H}_{298}^{\circ}
$$

$$
\mathrm{kJ} / \mathrm{mol} \quad \mathrm{kcal} / \mathrm{mol}
$$$$
-209.32 \quad(-50.03)
$$

$\mathrm{k}_{1}$

$\begin{array}{rrr}209.32 & (50.03) & \mathrm{k}_{2} \\ -103.97 & (-24.85) & \mathrm{k}_{3} \\ -62.81 & (-15.01) & \mathrm{k}_{4}\end{array}$

P(M)/torr Fast flow experiments with excess $\mathrm{NO}_{2}$ added to $\mathrm{H}$ atoms in $\mathrm{Ar}, \mathrm{T}=297 \mathrm{~K}$. OH detected

by resonance fluorescence ANDERSON, KAUFMAN, 1972 (b)

$\underline{\mathrm{T} / \mathrm{K}}$ Flash photolysis of $\mathrm{NO}_{2}$ in presence of $\mathrm{H}_{2}$ (2.5 or 15 torr) and No $(<0.4$ torr $)$. He added to bring total pressure to 30 torr. OH detected by U.V. absorption . MORLEY, SMITH, 1972 (c) 


$\frac{k^{\prime} \times 10^{31}}{\mathrm{~cm}^{6} \text { molecule } \mathrm{s}^{-2} \mathrm{~s}^{-1}}$

13

8.0

3.6

$\mathrm{k}_{1}(\mathrm{Ar}) / \mathrm{k}_{1}$ (He) $=0.45$ at $298 \mathrm{~K}$

$\frac{k^{\prime} \times 10^{1.3}}{\mathrm{~cm}^{3} \text { molecule } \mathrm{e}^{-1} \mathrm{~s}^{-1}}$

0.8

1.4

2.2

5
$\underline{\mathrm{T} / \mathrm{K}}$

273

298

398

$\underline{P(M) / \text { torr }}$

10

20

82
Flow experiment with

$\mathrm{OH}$ (from $\mathrm{H}+\mathrm{NO}_{2}$ )

and excess No.

$\mathrm{OH}$ detected by e.s.r.

$M=H e$ ( 0.5 to 5 torr $)$.

WESTENBERG, DeHAAS, 1972 (d)

$$
k^{\prime}=34 k_{3}+234 k_{4}
$$

(expression derived from data)

value reported:

$$
\begin{gathered}
\mathrm{k}^{\prime}=6 \times 10^{-12} \\
\mathrm{~cm}^{3} \text { molecule }
\end{gathered}
$$

Pulsed vacuum u.v.

photolysis of $\mathrm{H}_{2} \mathrm{O}$ in

presence of NO and excess

$\mathrm{He}(5-82$ torr $) . \mathrm{OH}$

detected by resonance

fluorescence

STUHL, NIKI, 1972 (e)

Photolysis of $\mathrm{N}_{2} \mathrm{O}$ (47 torr)

in presence of $\mathrm{H}_{2}$ (760 torr),

$\mathrm{O}_{2}$ (50 torr), Co (110 torr),

and NO (60 or 120 mtorr). $\Phi\left(\mathrm{NO}_{2}\right)$

measured. $T=300 \mathrm{~K}$.

SIMONAITIS, HEICKLEN, 1973 (f)

' $k$ ' is the pressure dependent rate constant defined by the expression:

$$
\mathrm{d}\left[\mathrm{HNO}_{2}\right] / \mathrm{dt}=\mathrm{k}^{\prime}[\mathrm{HO}][\mathrm{NO}]
$$




\section{Preferred values}

Preferred values of $k_{1}$ are given in Figure 1.

$\Delta \log k= \pm 0.5$

Values of $\mathrm{k}$ based on a $\mathrm{N}_{2}$ efficiency of 0.5

5. Remarks

Experimental results are in satisfactory agreement in the sense that al1 the data can be fitted with a maximum deviation of $\pm 40 \%$ (see Table 1 ). At the present time this is probably all that can be expected. The present fit is based on RRKM calculations $(g, h)$ assuming a loose complex [transition s,tate frequencies $3600,1600,60(2)$, and 40 yielding $k_{1}(300)=2 \times 10^{-11}$ $\mathrm{cm}^{3}$ molecule $\mathrm{s}^{-1}$ ] and with all overall rotations active. The last ignores angular momentum conservation. The justification is that in other cases when this is combined with the two adjustable parameters $k_{1}$ and $\lambda$ (collision efficiency) a satisfactory fit can be made over large temperature ranges (h). The symbol $\mathrm{k}_{1}$ denotes the limiting high pressure second order rate constant for reaction 1 . The approach is thus largely empirical. In this study $\lambda$ is .8 and the collision diameter $6.5 \AA$. Third body efficiencies are $\operatorname{He}(.42)$, $\mathrm{Ar}(.21)$, and $\mathrm{H}_{2}(1.0)$. All calculations are based on the more stable trans $-\mathrm{HNO}_{2}$ form. Values of $k_{1}$ calculated for the cis form are about $20 \%$ slower. Conversion to values of $k_{2}$ can be effected through the equilibrium constant $\log _{10} \mathrm{~K}_{\mathrm{P}}(\mathrm{atm})=7.7516-10976 / \mathrm{T}$ (derived from thermochemical data in ref. $\left.j_{.}\right)$.

6. Comments on measurements

ref $f$. The value reported for $k_{1}[M]$ is based on the values $k_{3}=1.35 \times 10^{-13}$ and $k_{4}=7.1 \times 10^{-15} \mathrm{~cm}^{3}$ molecule $\mathrm{s}^{-1}$ (i). 
Table 1. Comparison between Experimental and Calculated Values of $\mathrm{k}_{1}$

$$
\frac{k_{1} \times 10^{31}}{\mathrm{~cm}^{6} \text { molecule } \mathrm{e}^{-2} \mathrm{~s}^{-1}}
$$

$\underline{\operatorname{Ref}}$

$\underline{\mathrm{P}(M) / \text { torr }}$

5

8

(c) $\mathrm{He}$

30

(b) Ar

.

416

(d) $\mathrm{He}$

3

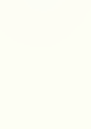

Ar

3

(e)

$$
\mathrm{He}
$$

$\begin{array}{ll}5 & 298 \\ 10 \\ 20 \\ 82\end{array}$

(f) $\mathrm{H}_{2}, \mathrm{CO}, \mathrm{O}_{2}, \mathrm{~N}_{2} \mathrm{O} \quad 970$ $\mathrm{X}\left(\mathrm{H}_{2}\right)=0.78$
$\mathrm{T} / \mathrm{K}$

297

Expt1.

Calc.

4

3.8

2.5

3.3

300

4.1

4.1

1.9

2.4

273

298

398

298

13

8.7

8

6.9

3.6

3.8

3.6

3.5

98

5.2

6.2

4.4

5.5

3.4

4.3

1.9

2.9

300

1.9

1.5 


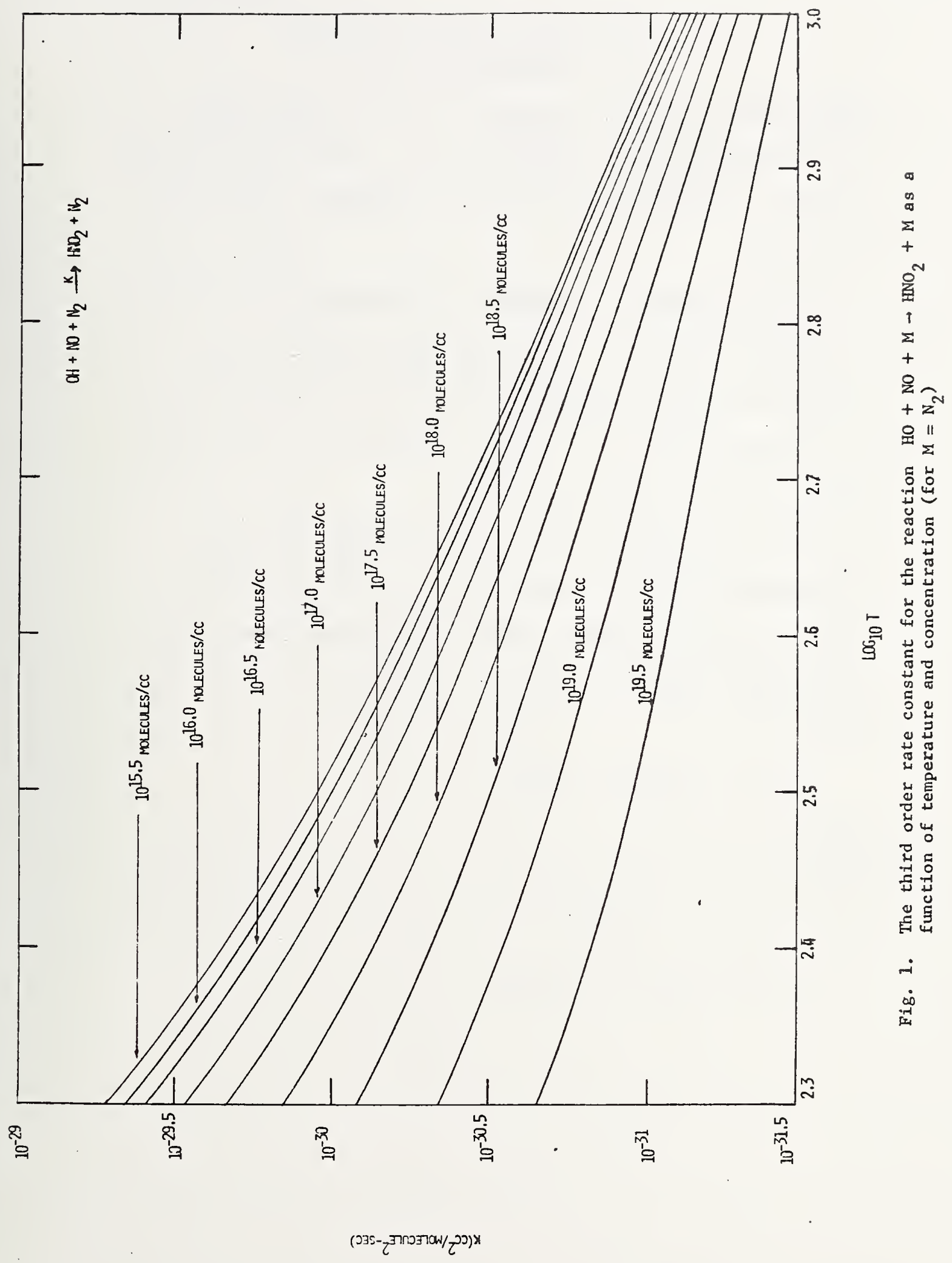




\section{References}

a. D. D. Wagman, et a1, NBS Technical Note 270-3 (Jan. 1968).

b. J. G. Anderson and F. Kaufman, Chem. Phys. Lett. 16, 375 (1972).

c. C. Morley and I. W. M. Smith, J. Chem. Soc. Far. Trans. II $\underline{68}$, 1016 (1972)

d. A. A. Westenberg and N. DeHaas, J. Chem. Phys. 57, 5375 (1972).

e. F. Stuhl and H. Niki, J. Chem. Phys. 57, 3677 (1972).

f. R. Simonaitis and J. Heicklen, J. Phys. Chem. 77, 1096 (1973).

g. P. J. Robinson and K. A. Holbrook, "Unimolecular Reactions", Wiley-Interscience, New York (1972).

h. W. Tsang, Int. J. Chem. Kinetics, to be published.

i. F. Stuhl and H. Niki, J. Chem. Phys. 57, 3671, 3677 (1972).

j. D. R. Stull and H. Prophet, JANAF Thermochemical Tables, 2d Edition, Nat. Stand. Ref. Data Ser., Nat. Bur. Stand. (US) 37, June 1971 .

W. Tsang

May 1973 


\section{Chemical Kinetics Data Survey}

The Combination of $\mathrm{HO}$ with $\mathrm{NO}_{2}$

1. Reaction evaluated

$$
\mathrm{HO}+\mathrm{NO}_{2}+\mathrm{M} \rightarrow \mathrm{HNO}_{3}+\mathrm{M}
$$

2. Related reactions

$$
\begin{aligned}
& \mathrm{HNO}_{3}+\mathrm{M} \rightarrow \mathrm{HO}+\mathrm{NO}_{2}+\mathrm{M} \\
& \mathrm{HO}+\mathrm{HNO}_{3} \rightarrow \mathrm{H}_{2} \mathrm{O}+\mathrm{NO}_{3} \\
& \mathrm{HO}+\mathrm{CO} \rightarrow \mathrm{CO}_{2}+\mathrm{H}
\end{aligned}
$$

\section{Data}

\section{a. Direct Studies}

\section{Results}

$$
\begin{aligned}
& \mathrm{k}_{1} / \mathrm{k}_{3}=2.2 \times 10^{-20} \\
& \mathrm{~cm}^{3} \text { molecule }
\end{aligned}
$$

$$
\begin{aligned}
& \mathrm{k}_{1}=1.6 \times 10^{-29} \\
& \mathrm{~cm}^{6} \text { molecule } \mathrm{m}^{-1}
\end{aligned}
$$

$\begin{array}{lll}\Delta \mathrm{H}_{298}^{\circ} & (\mathrm{a}, \mathrm{b}) \\ \mathrm{kJ} / \mathrm{mo} 1 & \mathrm{kcal} / \mathrm{mol} & \\ -207.2 & (-49.52) & \mathrm{k}_{1}\end{array}$

$\begin{array}{lll}207.2 & (49.52) & \mathrm{k}_{2} \\ -76 & (-18) & \mathrm{k}_{3} \\ -103.97 & (-24.85) & \mathrm{k}_{4}\end{array}$
$k_{4}$

2

.




$$
\begin{aligned}
& \mathrm{k}^{\prime} \times 10^{12^{*}} \\
& \mathrm{~cm}^{3 \text { molecule }^{-\mathrm{I}_{\mathrm{S}}}-1} \\
& \underline{T}=300 \mathrm{~K} \quad \mathrm{~T}=416 \mathrm{~K} \\
& 1 \\
& 0.4 \\
& 0.75 \\
& 2.0 \\
& 1.6 \\
& 3.3 \\
& k_{1}\left(\mathrm{H}_{2}\right) / k_{1}(\mathrm{He})=4 \pm 1 \\
& k_{\infty} / k_{4}=15 \exp (380 / T) \\
& \text { where } k_{c_{0}}=1 \text { imiting high } \\
& \text { pressure } 2 \text { nd order value for } k_{1} \\
& \mathrm{~cm}^{3} / \text { molecule } \quad \mathrm{M}=\mathrm{He}
\end{aligned}
$$$$
\underline{P(M) / \text { torr }}
$$

Flash photolysis of $\mathrm{NO}_{2}$ in presence of $\mathrm{H}_{2}$ at 300 and $416 \mathrm{~K}, 20-300$ torr $\mathrm{He}$, Followed disappearance of $\mathrm{OH}$ by resonance absorption.

MORLEY, SMITH, 1972 (e)

Photolysis of $\mathrm{NO}_{2}$ at $228.8 \mathrm{~nm}$ in presence of 3-20 torr $\mathrm{H}_{2} \mathrm{O}, 0-1000$ torr $\mathrm{He}, 1-350$ torr $\mathrm{CO}$, and 3-30 torr $\mathrm{NO}_{2}$ at 300 and $423 \mathrm{~K}$. Measured $\Phi\left(\mathrm{CO}_{2}\right)$.

SIMONAITIS, HEICKLEN, 1972 (f)

$\mathrm{k}_{1} \times 10^{30}$

$\begin{array}{cc}\mathrm{cm}^{6} \text { molecule } \mathrm{s}^{-1} & \frac{\mathrm{P}(\mathrm{Ar}) / \text { torr }}{1 \pm 0.3} \\ 0.8 & 0.5-3 \\ 0.6 & 10 \\ 2 & \mathrm{P}=8 \text { torr } \\ & \mathrm{X}\left(\mathrm{N}_{2}\right)=0.8 \\ & \mathrm{X}(\mathrm{Ar})=0.2\end{array}$

ANDERSON, KAUFMAN, 1972 (g)

' $k$ ' is the pressure dependent rate constant defined $b$ " the expressioñ $\mathrm{d}\left[\mathrm{MNO}_{3}\right] / \mathrm{dt} \cdots \mathrm{k}^{\prime}[\because \mathrm{O}]\left[\mathrm{HO}_{2}\right]$. 


$\begin{array}{ccc}\frac{\mathrm{k}_{1} \times 10^{30}}{\mathrm{~cm}^{6} \mathrm{molecule} \mathrm{s}^{-1}} & \text { M } & \underline{\mathrm{T} / \mathrm{K}} \\ 2.01 & \mathrm{He} & 273 \\ 1.57 & \mathrm{He} & 298 \\ 0.58 & \mathrm{He} & 398 \\ 0.83 & \mathrm{Ar} & 298 \\ \mathrm{~b} . \quad \text { Indirect Studies } & \\ \mathrm{k}_{2}[\mathrm{M}]=0.16 \mathrm{~s}^{-1} \\ {[\mathrm{M}]=1 \text { atm } \mathrm{N}_{2}, \mathrm{~T}=670 \mathrm{~K}}\end{array}$

$\underline{\mathrm{T} / \mathrm{K}}$

648

673

698

$\mathrm{P}\left(\mathrm{HNO}_{3}\right) \sim 3$ torr

$\mathrm{k}_{2}(\mathrm{M}) / \mathrm{k}_{2}\left(\mathrm{HNO}_{3}\right)$

$\underline{M}$

1

$\mathrm{H}_{2} \mathrm{O}$

0.25

$\mathrm{CO}_{2}$

0.15

$\mathrm{O}_{2}$

0.1

Ar
Decomposition of $\mathrm{HNO}_{3}$ in 1 atm $\mathrm{N}_{2}$ in static system. $\left[\mathrm{HNO}_{3}\right]$ and $\left[\mathrm{NO}_{2}\right]$ determined by absorption. JOHNSTON et a1, 1953 (i)

Decomposition of $\mathrm{HNO}_{3}$ in static system. $\mathrm{P}\left(\mathrm{t} \mathrm{O}_{3}\right)$ was 3.5-20 torr. $\left[\mathrm{NO}_{2}\right]$ determined by absorption. 


$$
\mathrm{HO}+\mathrm{NO}_{2}+\mathrm{M} \quad 4
$$

$k_{2}=2.6 \times 10^{-9} \exp (-15,400 / \mathrm{T})$

$\mathrm{cm}^{3}$ molecule $\mathrm{e}^{-1} \mathrm{~s}^{-1}$

$k_{2}[M]=0.012 \mathrm{~s}^{-1}$
Shock tube study of $\mathrm{HNO}_{3}$

decomposition in 500 torr Ar

$\left(2-4 \% \mathrm{HNO}_{3}\right)$ at $800-1200 \mathrm{~K}$.

Rate determined from $\mathrm{NO}_{2}$

appearance.

HARRISON et a1, 1962 (k)

Decomposition of $\mathrm{HNO}_{3}$ at $622 \mathrm{~K}$

in $\mathrm{N}_{2} ; \mathrm{P}^{\prime}\left(\mathrm{lll} \mathrm{O}_{3}\right) \sim 30$ torr, total

pressure 680 and 230 torr. Rate

determined from $\triangle\left[\mathrm{HNO}_{3}\right]$ and agrees

with that determined from $\triangle\left[\mathrm{NO}_{2}\right]$.

GODFREY, et a1, 1965 (l)

\section{Preferred value}

Preferred values of $k_{1}$ are given in Figure 1.

$\triangle \log k= \pm 0.3$

Values of $k$ based on a $\mathrm{N}_{2}$ efficiency of 0.26

\section{5. $\quad \underline{\text { Remarks }}$}

The fit of the data is based on RRKM calculations $(o, p)$

a loose complex and overall rotations active. The transition state structure is $3600,1600(2), 760,40(2)$ and 2 free internal rotors $\left(1.6 \times 10^{-40} \mathrm{~g}-\mathrm{cm}^{2}\right)$. This yields $\mathrm{k}_{1 \infty}(300 \mathrm{~K})=1.0 \times 10^{-11} \mathrm{~cm}^{3}$ molecule $\mathrm{e}^{-1} \mathrm{~s}^{-1}$. The collision diameter is $6.5 \mathrm{~A}$ and the collision efficiency is 1 . The third body efficiencies are $\mathrm{HNO}_{3}=1.00$, $\mathrm{He}=.26$, Ar $=.12$, and $\mathrm{N}_{2}=.26$. A summary of the data on third body effects can be found in Table 3. A satisfactory fit can also be obtained with a 
transition-state model with an elongated central bond (factor of 3 ) and with the overa 11 rotation about this bond as active. (p).

Except for ref. $c$ and d, results can be fitted to within a factor of 2. This is summarized in Tables 1 and 2 . Note that the data range from .5 torr to an atmosphere and 273-1100 $\mathrm{K}$ and involves the forward and reverse reactions. The larger discrepancies of ref. c and d (compared to the other results) can be attributed to errors in specification of the reaction mechanism.

\section{Comments on measurements}

ref c. From the measured $k_{1} / k_{3}$, taking the value of $\mathrm{k}_{3}=1.4 \times 10^{-13} \mathrm{~cm}^{3}$ molecule $\mathrm{s}^{-1}$ (ref $\mathrm{m}$ ), the value $\mathrm{k}_{1}=$ $3 \times 10^{-33} \mathrm{~cm}^{6}$ molecule $1 \mathrm{e}^{-2} \mathrm{~s}^{-1}$ is derived. Note that in nitric acid systems at low temperatures, reactions are often subject to surface effects.

ref. d. This is basically a qualitative study with respect to the process of interest.

ref. f. The value of $k_{3}$ used in the present analysis to get the values of $k_{1}$ in Table 1 is $1.33 \times 10^{-13} \mathrm{~cm}^{3}$ molecule $\mathrm{s}^{-1}$ (n). ref. $i$ and $l$. This fit does not substantiate the claims that the measured rates are in the limiting high pressure region. The present results indicate that $\mathrm{k}_{2}[\mathrm{M}] / \mathrm{k}_{2}{ }^{\infty} \sim 0.1$. 
Table 1 Comparison between Experimental and Calculated Values of $k_{1}$

$$
\frac{k_{1} \times 10^{31}}{\mathrm{~cm}^{6} \text { molecule } \mathrm{e}^{-2} \mathrm{~s}^{-I}}
$$

$\underline{\operatorname{Ref}} \quad \underline{\mathrm{P}(\mathrm{M}) / \operatorname{torr}} \quad \underline{\mathrm{T} / \mathrm{K}} \quad \underline{\text { Expt1. }} \underline{\mathrm{Ca} 1 \mathrm{C}}$

(h) $\mathrm{He}$

273

20

22

3

298

16

18

3

398

6

11

Ar

3

298

8

10

(e) $\mathrm{He}$

30

300

10.4

8.6

100

6.2

5.3

300

3.5

2.9

$\mathrm{He}$

30

416

5.8

6.1

100

3.3

4.3

300

2.2

2.7

(f) $\mathrm{He}$

30

300

13.6

8.6

100

9.5

5.3

300

5.2

2.9

1000

1.9

1.4

$\mathrm{He}$

30
100
300
1000

423

8.6

5.8

6.7

4.1

4.1

2.6

1.8

1.5 


$$
\frac{k_{1 \times 10^{31}}}{\mathrm{~cm}^{6} \text { molecule } \mathrm{s}^{-1}}
$$

$\begin{array}{lccccc}\frac{\text { Ref. }}{\text { (g) }} & \frac{\mathrm{M}}{\mathrm{Ar}} & \frac{\mathrm{P}(\mathrm{M}) / \text { torr }}{.5-3} & \frac{\mathrm{T} / \mathrm{K}}{297} & \frac{\text { Expt1 }}{10} & \frac{\text { Calc. }}{12} \\ & & 6 & & 8 & 8 \\ & 10 & & 6 & 7.5 \\ & \mathrm{~N}_{2}, \mathrm{Ar} & 8 & 297 & 20 & 19 \\ \text { (c) } \quad \mathrm{Kr} & 300 & 300 & .03 & 2 \\ \text { (d) } \quad \mathrm{Ar} & 1 & 300 & 170 & 10\end{array}$


Table 2 Comparison between Experimental and Calculated Values for $\mathrm{k}_{2}$

\begin{tabular}{|c|c|c|c|c|c|}
\hline \multirow[b]{3}{*}{$\underline{\operatorname{Ref}}$} & \multirow[b]{3}{*}{$\underline{\mathrm{M}}$} & \multirow[b]{3}{*}{$\underline{P(M) / \text { torr }}$} & \multirow[b]{3}{*}{$\mathrm{T} / \mathrm{K}$} & \multicolumn{2}{|c|}{$k_{2} \times 10^{19}$} \\
\hline & & & & \multicolumn{2}{|c|}{$\mathrm{cm}^{3}$ molecule $\mathrm{s}^{-1}$} \\
\hline & & & & Expt 1 & Calc. \\
\hline \multirow[t]{3}{*}{ (k) } & Ar & 500 & 900 & 980 & 800 \\
\hline & & & 1000 & 5000 & 9000 \\
\hline & & & 1100 & 25000 & 50000 \\
\hline \multirow[t]{3}{*}{ (j) } & $\mathrm{HNO}_{3}$ & 3 & 648 & .53 & .63 \\
\hline & & & 673 & 1.7 & 2.3 \\
\hline & & & 698 & 4.8 & 8.0 \\
\hline$(l)$ & $\mathrm{N}_{2}$ & 760 & 622 & .012 & .014 \\
\hline (i) & $\mathrm{N}_{2}$ & 760 & 670 & .15 & .22 \\
\hline
\end{tabular}




$$
\mathrm{HO}+\mathrm{NO}_{2}+\mathrm{M} \quad 9
$$

Table 3. Summary of Experimental Data on Third Body Effects

\begin{tabular}{|c|c|c|c|c|c|}
\hline$\underline{M}$ & Ref.j & Ref. e & $\underline{\text { Ref. } f}$ & Ref. h & Ref. $g$ \\
\hline $\mathrm{HNO}_{3}$ & 1 & & & & \\
\hline $\mathrm{He}$ & & 1 & 1 & 1 & \\
\hline Ar & $\sim 0.1$ & & & 0.5 & 1 \\
\hline $\mathrm{H}_{2} \mathrm{O}$ & $\sim 1$ & & 8 & & \\
\hline $\mathrm{SF}_{6}$ & & 4.8 & & & \\
\hline $\mathrm{CO}_{2}$ & $\sim 0.25$ & & & & \\
\hline $\mathrm{N}_{2}$ & & & & & 2.2 \\
\hline $\mathrm{H}_{2}$ & & 4.0 & & & \\
\hline $\mathrm{O}_{2}$ & $\sim 0.15$ & & & & \\
\hline $\mathrm{CO}$ & & & 1.5 & & \\
\hline
\end{tabular}




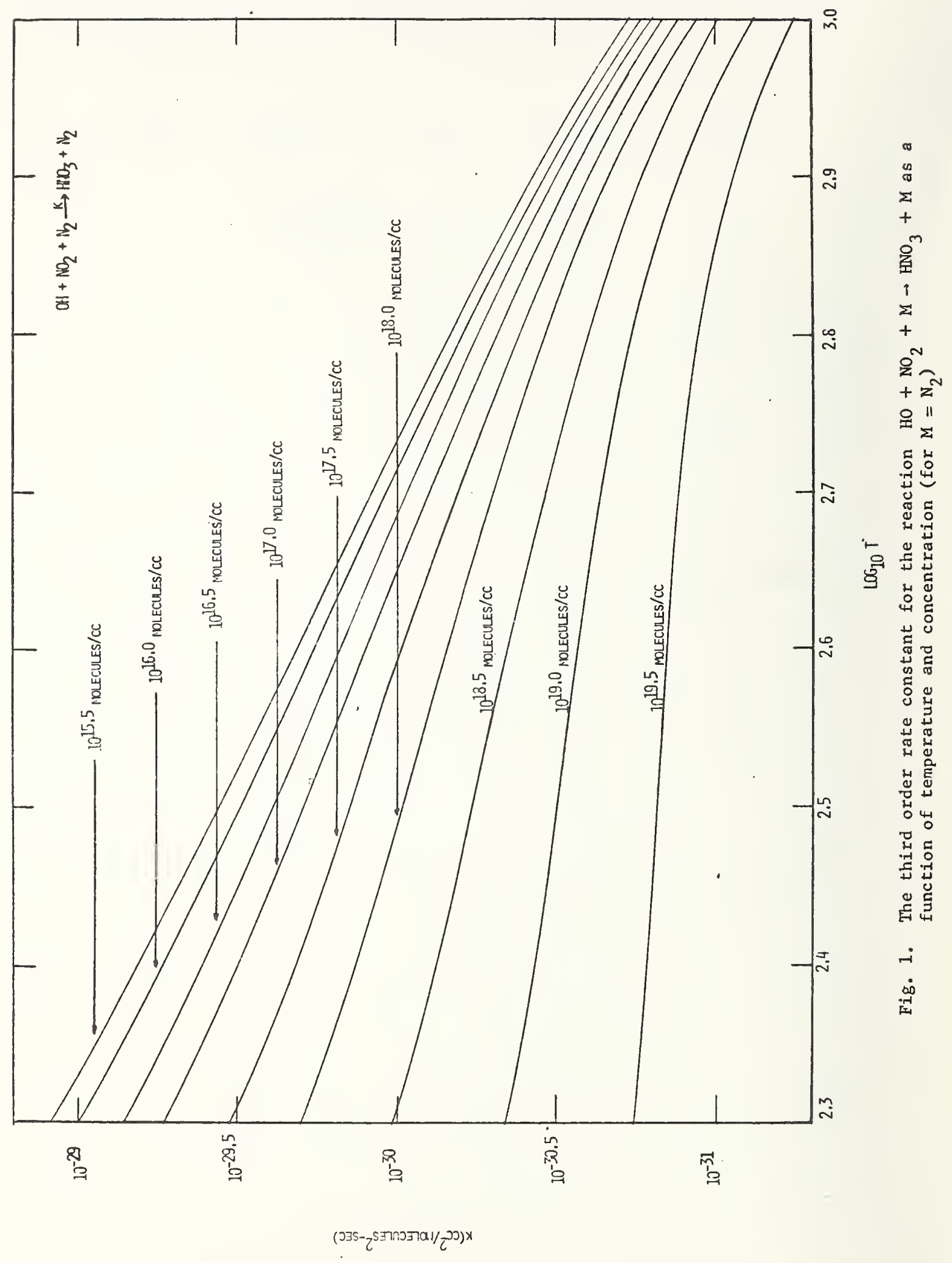




$$
\mathrm{HO}+\mathrm{NO}_{2}+\mathrm{M}
$$

\section{References}

a. D. D. Wagman, et a1, NBS Technical Note 270-3 (Jan. 1968).

b. D. R. Stul1 and H. Prophet, "JANAF Thermochemica1 Tables, 2d Ed," Nat. Stand. Ref. Data Ser. Nat. Bur. Stand. (U. S.), 37 (June 1971).

c. T. Berces and S. Forgeteg, Trans. Faraday Soc. 66, 640 (1970).

d. M. F. R. Mulcahy and R. H. Williams, J. Chem. Phys. 54, 5215 (1971)

e. C. Morley and I. W. M. Smith J. Chem. Soc., Far. Trans. II, 68 1016 (1972).

f. R. Simonaitis and J. Heicklen, Int. J. Chem. Kinetics 44, 529 (1972).

g. J. G. Anderson and F. Kaufman, Chem. Phys. Lett. 16, 375 (1972).

h. A. A. Westenberg and N. deHaas, J. Chem. Phys. 57, 5375 (1972).

i. H. S. Johnston, L. Foering, and R. J. Thompson, J. Phys. Chem. 57, 390 (1953).

j. H. S. Johnston, L. Foering and J. R. White, J. Am. Chem. Soc. 77, $4208(1955)$.

k. H. Harrison, H. S. Johnston and E. R. Hardwicke, J. Am. Chem. Soc. 84,2478 (1962).

Ł. T. S. Godfrey, E. D. Hughes and C. Ingold, J. Chem. Soc. 1063 (1965). 


$$
\mathrm{HO}+\mathrm{NO}_{2}+\mathrm{M}
$$

m. R. F. Hampson et a1, "Survey of Photochemical and Rate Data for Twenty-Eight Reactions of Interest in Atmospheric Chemistry", to be published J. Phys. Chem. Ref. Data $\underline{2}$, No. 2 (1973).

n. A. A. Westenberg and N. deHaas, J. Chem. Phys: 58, 4061 (1973).

o. P. J. Robinson and K. A. Holbrook, Unimolecular Reactions, Wi ley-Interscience, New York (1972).

p. W. Tsang, Int. J. Chem. Kinetics, to be published.

W. Tsang

May, 1973 
Photochemistry of NO

1. Primary Photochemical Transitions

a. Dissociation

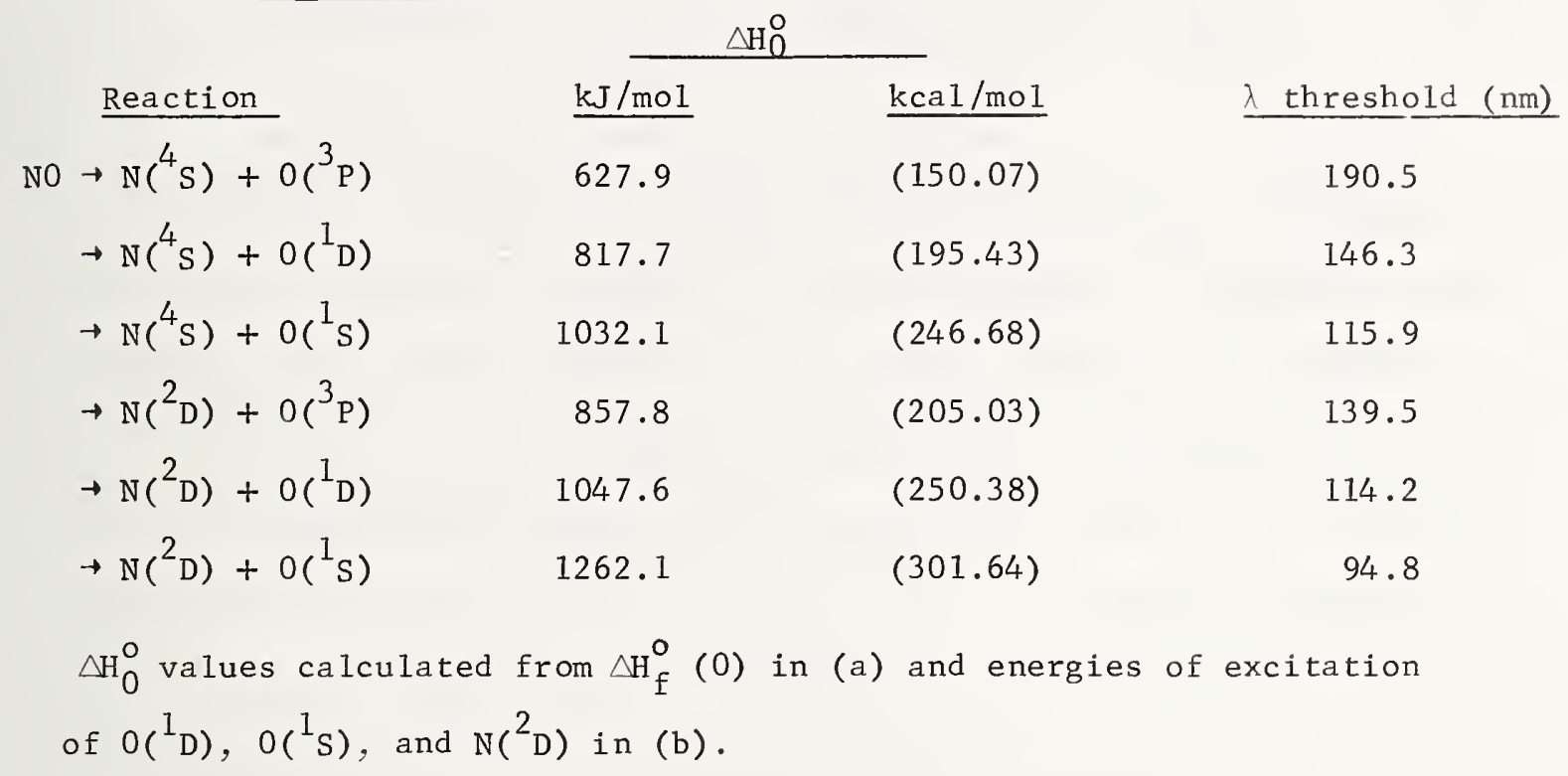

The bond dissociation energy has been determined to be $52400 \pm$ $10 \mathrm{~cm}^{-1}$ or $626.84 \pm 0.12 \mathrm{~kJ} / \mathrm{mol}(149.82 \pm 0.03 \mathrm{kcal} / \mathrm{mol})$ (c). This energy corresponds to a threshold wavelength of $190.8 \mathrm{~nm}$.

b. Electronic Energy Levels of NO and Transitions

\begin{tabular}{|c|c|c|c|}
\hline$\underline{\text { State }}$ & $\mathrm{T}_{0} / \mathrm{cm}^{-1}$ & $\lambda(\mathrm{vac}) / \mathrm{nm}$ & Transitions \\
\hline$\left.{ }^{2} \Sigma^{+}\right)$ & 53291 (a) & 187.65 & $D \rightarrow X(\xi)$ \\
\hline$c($ & 52372 (a) & 190.94 & $C \rightarrow X(\delta)$ \\
\hline$B\left({ }^{2} \Pi_{r}\right)$ & 45505 (a) & 219.76 & $B \rightarrow X(\beta)$ \\
\hline$A\left({ }^{2} \Sigma^{+}\right)$ & 44199.2 (a) & 226.25 & $A \rightarrow X(\gamma)$ \\
\hline a & $37965 \pm 25$ (b) & 263 & - \\
\hline$x\left({ }^{2} \pi_{1 / 2}\right)$ & 0 & - & - \\
\hline $\begin{array}{l}\text { a. From } \\
\text { b. From }\end{array}$ & $\begin{array}{l}\text { ref. (x) } \\
\text { ref. (y) }\end{array}$ & & \\
\hline
\end{tabular}




\section{Absorption Coefficient Data}

The spectroscopy of NO a bsorption bands has been studied in detail. It is summarized in reference (x). See also references $(f, z)$ for examples of the complexities that occur.

Hudson (h) in 1971 reviewed the u.v. absorption coefficient measurements on NO, with emphasis on data for $\lambda<160 \mathrm{~nm}$. Marmo (d) and Thompson, Harteck and Reeves (e) reported absorption coefficients covering the range $110<\lambda<230 \mathrm{~nm}$. These coefficients are not independent of the resolution of their instruments except possibly for $\lambda<130 \mathrm{~nm}$. See Figures 1 and 2 for a qualitative view of the spectrum.

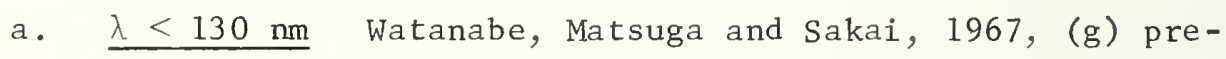
sented extensive tables of absorption coefficients and photoionization yields. For the range $106<\lambda<135 \mathrm{~nm}$ these are based on measurements in a $10 \mathrm{~cm}$ long cell with $0.02 \mathrm{~nm}$ band pass. There is reasonable agreement with (d).

\section{b. Banded absorption Integrated absorption coefficients} and oscillator strengths have been measured for the $\beta, \gamma, \delta$ and \& band systems. These are summarized below as oscillator strengths, $\mathrm{f}\left(\mathrm{v}^{\prime}, \mathrm{v}^{\prime \prime}\right)$ for individual bands. $\underline{v}^{\prime}$ is the vibrational quantum number in the upper state, $v^{\prime \prime}$ is that in the ground state. This oscillator strength is related to the integrated absorption coefficient for the same band via

$$
\begin{gathered}
\mathrm{f}\left(\mathrm{v}^{\prime}, \mathrm{v}^{\prime \prime}\right)=\left(\mathrm{mc}^{2} / \Pi \mathrm{e}^{2} \mathrm{~N}_{\mathrm{o}}\right)\left(\mathrm{K}_{\mathrm{o}} / \mathrm{F}\left(\mathrm{v}^{\prime \prime}\right)\right) \\
=4.203 \times 10^{-8}\left(\mathrm{~K}_{\mathrm{o}} / \mathrm{F}\left(\mathrm{v}^{\prime \prime}\right)\right)
\end{gathered}
$$


where $c$ is the velocity of light, $m$ and e are the mass and charge of the electron, $N_{0}$ is the number of molecules per $\mathrm{cm}^{3}$ at 1 atm. and $273.15 \mathrm{~K}$, and $\mathrm{F}\left(\mathrm{v}^{\prime \prime}\right)$ is the fraction of these molecules in the lower vibrational state (under the conditions of the experiment). $\mathrm{K}_{\mathrm{o}}$ is in $\mathrm{cm}^{-2} \mathrm{~atm}^{-1}$.

Methods of measurement. Bethke 1959 (aa), measured integrated absorption coefficients photometrically for NO pressurized with argon. Callear and Pilling, 1970 (bb), used a similar spectrographic studies and analysis of fluorescence intensities. Farmer et al, 1972 (cc) and Pery-Thorne and Banfield, 1970 (dd) measured refractive index dispersion near absorption lines. Marr, 1964 (ee), reanalyzed the earlier data and presented smoothed values for many transitions in the $v$ and $B$ bands.

\section{Oscillator Strengths}

$\begin{array}{llll}\mathrm{v}^{\prime}, \mathrm{v}^{\prime \prime} & 10^{\frac{B}{4} \mathrm{f}\left(\mathrm{v}^{\prime} \mathrm{v}^{\prime \prime}\right)} & \mathrm{v}^{\prime}, \mathrm{v}^{\prime \prime} & 10^{4} \mathrm{f}\left(\mathrm{v}^{\prime}, \mathrm{v}^{\prime \prime}\right) \\ 2,0 & 0.0155 \pm 10 \% & 9,0 & 3.58 \pm 10 \% \\ 3,0 & 0.0461 \pm 10 \% & 11,0 & 3.62 \pm 20 \% \\ 4,0 & 0.138 \pm 20 \% & 12,0 & 23.1 \pm 10 \% \\ 5,0 & 0.264 \pm 10 \% & 14,0 & 2.006 \pm 10 \% \\ 6,0 & 0.462 \pm 20 \% & & \end{array}$


$y$ bands $(A-X)$

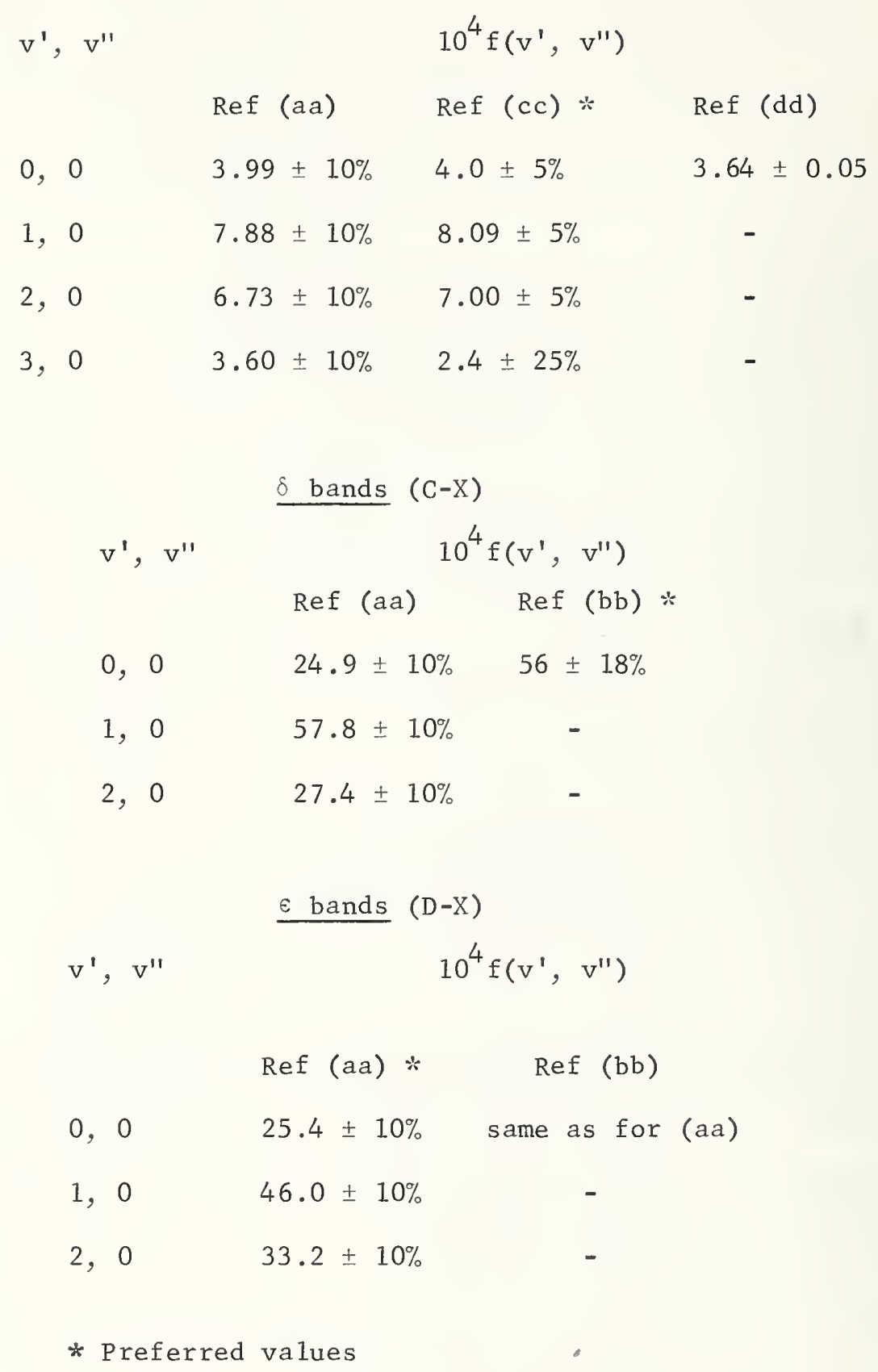


3. Photochemical data

There have been two recent reviews of the photochemistry of NO:

1) Heicklen and Cohen, 1968, (ref. i), and 2) Preston and Cvetanovic, 1972, (ref j).

a. $\lambda>191 \mathrm{~nm}$

Table I summarizes the results of studies of the photochemistry of NO at photon energies less than the dissociation energy.

Absorption produces an excited NO. Products are formed exclusively from reactions of this excited molecular species.

\section{MECHANISM:}

$$
\begin{aligned}
\mathrm{NO}+\mathrm{h \nu} & \rightarrow \mathrm{NO} * \\
\mathrm{NO}^{*} & \rightarrow \mathrm{NO}+\mathrm{hv} \\
\mathrm{NO}^{*}+\mathrm{NO} & \rightarrow 2 \mathrm{NO} \\
\mathrm{NO}^{*}+\mathrm{NO} & \rightarrow \mathrm{N}_{2}+\mathrm{O}_{2} \\
\mathrm{NO}^{*}+\mathrm{NO} & \rightarrow \mathrm{N}_{2} \mathrm{O}+\mathrm{O} \\
2 \mathrm{NO}+\mathrm{O}_{2} & \rightarrow 2 \mathrm{NO}_{2}
\end{aligned}
$$

b. $\lambda<191 \mathrm{~nm}$

Table II summarizes the results of studies of the photochemistry of NO at photon energies greater than the dissociation energy. $\Phi\left(\mathrm{N}_{2}\right)$ is always < 1 , indicating that absorption produces bound excited states which can fluoresce or be collisionally quenched or dissociate. Products are formed by atom-molecule reactions. 
MECHANISM:

$$
\begin{aligned}
& \mathrm{NO}+\mathrm{h \nu} \rightarrow \mathrm{NO}^{*} \\
& \mathrm{NO}^{*} \rightarrow \mathrm{NO}+\mathrm{h \nu} \\
& \mathrm{NO}+\mathrm{M} \rightarrow \mathrm{NO}+\mathrm{M} \\
& \mathrm{NO}+\mathrm{M} \rightarrow \mathrm{N}+\mathrm{O}+\mathrm{M} \\
& \mathrm{N}+\mathrm{NO} \rightarrow \mathrm{N}_{2}+\mathrm{O} \\
& \mathrm{O}+\mathrm{NO}+\mathrm{M} \rightarrow \mathrm{NO}_{2}+\mathrm{M}
\end{aligned}
$$

Table I. Summary of data on photochemistry of NO at energies less than the dissociation energy (i.e. at $\lambda>191 \mathrm{~nm}$ ).

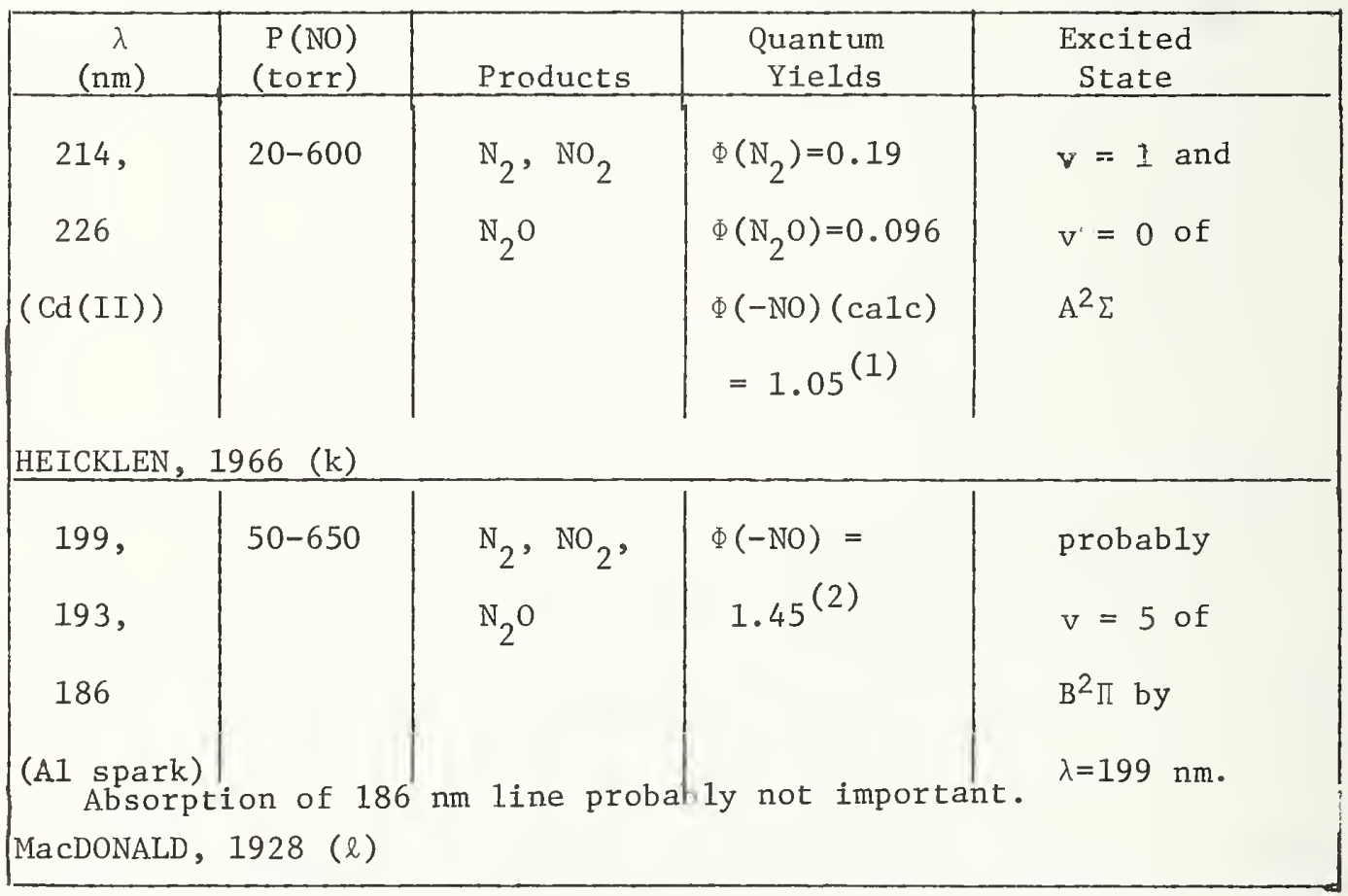

Note 1. Obtained indirectly; based on mechanism assuming $\Phi\left(\mathrm{N}_{2} \mathrm{O}\right)=2$ in presence of large conc. of $\mathrm{CH}_{4}$.

Note 2. Obtained directly; incident light intensity measured by irradiation of thermocouple. 
Table II. Summary of data on photochemistry of NO at energies greater than the dissociation energy (i.e. at $\lambda<191 \mathrm{~nm}$ ).

\begin{tabular}{|c|c|c|c|c|}
\hline $\begin{array}{c}\lambda \\
(\mathrm{nm}) \\
\end{array}$ & $\begin{array}{l}\mathrm{P}(\mathrm{NO}) \\
\text { (torr) }\end{array}$ & Products & $\begin{array}{l}\text { Quantum (1) } \\
\text { Yields }\end{array}$ & $\begin{array}{c}\text { Excited } \\
\text { State }\end{array}$ \\
\hline $\begin{array}{l}\sim 160 \\
\left(\mathrm{H}_{2} \text { dis- }\right. \\
\text { charge) }\end{array}$ & $2-500$ & $\mathrm{~N}_{2}, \mathrm{NO}_{2}$ & $\begin{array}{l}\Phi\left(\mathrm{N}_{2}\right)=.2-.4 \\
\Phi\left(\mathrm{NO}_{2}\right)=.3-.7 \\
\Phi(-\mathrm{NO})= \\
0.8-1.8\end{array}$ & $\begin{array}{l}\mathrm{A}^{2} \Sigma, \mathrm{B}^{2} \Pi \\
\mathrm{C}^{2} \Pi, \mathrm{D}^{2} \Sigma\end{array}$ \\
\hline 147 & $10-700$ & $\begin{array}{l}\mathrm{N}_{2}, \mathrm{NO}_{2} \\
\mathrm{~N}_{2} \mathrm{O}^{(2)}\end{array}$ & $\begin{array}{l}\Phi\left(\mathrm{N}_{2}\right)=.3-.5 \\
\Phi\left(\mathrm{NO}_{2}\right)=.6-1.1 \\
\Phi\left(\mathrm{N}_{2} \mathrm{O}\right)=.02-.1 \\
\Phi(-\mathrm{NO})= \\
\quad 1.3-2.7\end{array}$ & $\begin{array}{l}v=7 \text { of } \\
D^{2} \Sigma \\
v=3 \text { of } \\
E^{2} \Sigma\end{array}$ \\
\hline LEIGA，TA & LOR, 196 & $\mathrm{~N}_{2}, \quad \mathrm{NO}_{2}$ & $\begin{array}{l}\Phi\left(\mathrm{N}_{2}\right)=.2-.5 \\
\Phi\left(\mathrm{NO}_{2}\right)=.4-1.0 \\
\Phi(-\mathrm{NO})= \\
1.0-2.3\end{array}$ & $\mathrm{NO}^{+}(3)$ \\
\hline $\begin{array}{l}\text { 183.2 } \\
\text { (Hg arc) } \\
\text { and meta1 } \\
\text { spark } \\
\text { sources }\end{array}$ & $0.07-7$ & $\mathrm{~N}_{2}, \mathrm{NO}_{2}$ & $\begin{array}{l}\text { only dcmp. } \\
\text { rate of } \\
\text { No meas. }\end{array}$ & $\begin{array}{l}v=1 \text { of } \\
\mathrm{C}^{2} \Pi \text { with } \\
\text { perhaps some } \\
\text { abs. to } v=9 \\
\text { of } B^{2} \Pi\end{array}$ \\
\hline FLORY, J & STON, & & & \\
\hline
\end{tabular}

Note 1. $\Phi$ values in ref $(l)$ based on $\Phi\left(\mathrm{O}_{3}\right)=2$ in photolysis of 1 atm. $\mathrm{O}_{2}$ flowing through reaction vessel.

Note 2. Secondary product from $\mathrm{N}+\mathrm{NO}_{2}$ (see ref. o).

Note 3. Ionization potential of $\mathrm{NO}=9.25 \mathrm{eV}$ (corresponds to $\lambda=134 \mathrm{~nm}$; at $123.6 \mathrm{~nm}$ the ionization yield is $0.77(\mathrm{~g})$. 
In addition to these studies giving values of quantum yields of product formation, the wavelength dependence of the formation of oxygen atoms from photolysis of NO has been studied by Stuhl and Niki (u). They detected 0 atoms (by $\mathrm{NO}_{2}{ }^{*}$ emission) when $\mathrm{NO}$ was photolyzed at $\lambda>160 \mathrm{~nm}$ and at $\lambda>180 \mathrm{~nm}$ but not at $\lambda>210 \mathrm{~nm}$. These observations are consistent with the value of the thermochemical threshold for photodissociation (191 nm).

4. Excited States of NO

a. Lifetimes

(1) Mean lifetimes (1/e) of low-lying excited states of NO with respect to spontaneous radiation and predissociation.

$\begin{array}{lcc}\text { State } & \frac{\text { Lifetime } \tau_{0} / \mathrm{s}}{2} & \text { Reference } \\ \mathrm{A}^{2} \Sigma & 2 \times 10^{-7} & (\mathrm{p}) \\ \mathrm{B}^{2} \Pi & 3 \times 10^{-6} & (\mathrm{q}) \\ \mathrm{C}^{2} \Pi & 6 \times 10^{-10}(\mathrm{a}) & (\mathrm{c}) \\ \mathrm{D}^{2} \Sigma & 2 \times 10^{-8} & (\mathrm{r}) \\ \text { Note (a): predissociation at limiting high [Ar]. } & \end{array}$


(2) Specific rate constants for spontaneous radiation and predissociation (all paths). From reference (c).

$$
\text { Rate constant, } \mathrm{k} / \mathrm{s}^{-1}
$$

\begin{tabular}{|c|c|c|c|}
\hline State & $\begin{array}{l}\text { emission } \\
\text { to } \mathrm{X}^{2} \Pi\end{array}$ & $\begin{array}{l}\text { emission } \\
\text { to } \mathrm{A}^{2} \sum \\
\end{array}$ & predissociation \\
\hline $\mathrm{A}^{2} \Sigma$ & $0.51 \times 10^{7}$ & -- & -- \\
\hline$C^{2} \pi$ & $5.1 \times 10^{7}$ & $3.5 \times 10^{7}$ & $1.65 \times 10^{9}$ (a) \\
\hline $\mathrm{D}^{2} \Sigma$ & $4.1 \times 10^{7}$ & $0.95 \times 10^{7}$ & $<0.8 \times 10^{7}$ \\
\hline
\end{tabular}

b. Quenching of excited states

The table below gives ratios of total quenching coefficients, $\mathrm{k}_{\mathrm{Q}}$, in $\mathrm{cm}^{3}$ molecule $\mathrm{e}^{-1} \mathrm{~s}^{-1}$, to total spontaneous decay rates, i.e. predissociation plus radiative transitions, $1 / \tau_{0}\left(\right.$ or $\left.k_{p}+\sum k_{r}\right)$, in reciprocal seconds. These are based on the quenching half pressure, i.e. that pressure of added gas which reduces the intensity of fluorescence to one-half its value in the absence of added gas. Data from reference (c) and at $298 \mathrm{~K}$ except as indicated.

The following formula relates the quenching coefficient, $k_{Q}$ in $\mathrm{cm}^{3}$ molecule $\mathrm{s}^{-1}$, the radiative lifetime, $\tau_{0}$ in $\mathrm{s}$, and the half pressure, $\mathrm{P}_{0.5}$ in $\mathrm{kN} \mathrm{m}^{-2}$.

$$
\mathrm{k}_{\mathrm{Q}} \cdot \tau_{0}=4.1 \times 10^{-18} / \mathrm{P}_{0.5}
$$




$$
10^{18} \mathrm{k}_{\mathrm{Q}} \cdot \tau_{0} / \mathrm{cm}^{3} \text { molecule } \mathrm{e}^{-1}
$$

$\begin{array}{lccccc}\text { State } & \underline{\mathrm{N} O} & \underline{\mathrm{N}_{2}} & \underline{\mathrm{Ar}} & \underline{\mathrm{CO}_{2}} & \underline{\mathrm{O}_{2}} \\ \mathrm{~A}\left({ }^{2} \Sigma\right) & 47 & .0164 & <0.016 & 79 & 34(\mathrm{a}) \\ \mathrm{C}\left({ }^{2} \Sigma\right) & 2.34 & 0.91 & <0.008 & 2.0 & \\ \mathrm{D}\left(^{2} \Sigma\right) & 71 & 5.6 & 3.08 & 22.8 \\ \text { State } & \underline{\mathrm{N}_{2} \mathrm{O}} & \underline{\mathrm{H}_{2}} & \underline{\mathrm{H}_{2} \mathrm{O}} & \underline{\mathrm{CO}_{2}} \\ \mathrm{~B}\left({ }^{2} \Pi\right) & 140(\mathrm{~b}, \mathrm{c}) & 60(\mathrm{~b}, \mathrm{c}) & <1500(\mathrm{~b}, \mathrm{c}) & 30(\mathrm{~b}, \mathrm{c}) .\end{array}$

(a) Reference (s), data on $\mathrm{O}_{2}$

(b) Reference ( $t$ )

(c) $T=196 \mathrm{~K}$

(Use values of $\tau_{0}$ in section $4 a$ to obtain $k_{Q}$ from the table)

5. Preferred values

a. Absorption coefficients

i) Banded spectra (data in section 2b)

$\beta$ bands. Use data from (aa)

$\checkmark$ bands. Use data from (cc)

$\delta$ bands. Use data from (bb) See remarks

$\varepsilon$ bands. Use data from (aa)

ii) $\lambda<130 \mathrm{~nm}$. Use data from (g) 


\section{b. Quantum yie1ds}

No general recommendations. Product yields depend upon the composition of the mixture being photolyzed and the wavelength of the exciting light. See remarks for some estimates pertinent to absorption in the atmosphere.

\section{Remarks}

\section{a. Absorption coefficients}

(i) $\lambda>130 \mathrm{~nm}$. The spectrum is highly structured. The apparent absorption coefficients that have been measured depend strongly upon instrumental resolution. Figure 1 may be used only to locate the wavelengths where absorption occurs but not to obtain the magnitude of the absorption coefficient.

Values for absorption coefficients, either for bands or lines, should be developed from oscillator strengths, $f\left(v^{\prime}, v^{\prime \prime}\right)$, populations of absorbers and line strength formulae. See (w) for application of the technique to No.

The oscillator strength for $\delta(0,0)$ measured by Callear and Piling (bb) is preferred to Bethke's (aa) because it is based on two methodsintegrated absorption and fluorescence lifetimes-that agree. This agreement is an argument that large systematic biases are absent from the spectrographic measurements. The value from (bb) is 2.25 times that from (aa). 
Oscillator strengths for $\delta(1,0$ and $\delta(2,0)$ are available only from (aa). Should they be used as is, or increased, i.e., normalized to the $\delta(0,0)$ reported in $(\mathrm{bb})$ ? Two arguments suggest that they should be increased. First, the reported oscillator strengths vary approximately as do the Franck-Condon factors. Secondly, Callear and Pilling show that collisional (pressure) broadening is much weaker for the $\delta(0,0)$ than the $\epsilon(0,0)$ band. This suggests that the $\delta$ bands were insufficiently broadened in Bethke's experiments. The argument is weak because of the high pressures (100 psia) of argon used by Bethke.

Arbitrarily we suggest that the $\delta(1,0)$ and $\delta(2,0)$ oscillator strengths from (aa) given in section 2 b should be multiplied by 2.25 . When these new values are used in aeronomic calculations they should be considered to be upper limits.

(ii) $\lambda<130 \mathrm{~nm}$. Absorption into a continuum is the most important element here. The higher resolution study ( $g$ ) has been selected. The data in Figure 2 are in reasonable agreement. 
6.b. Quantum Yields

Product formation following absorption of light by NO. Bound excited states of NO, $a^{4} \Pi, A^{2} \Sigma^{+}, B^{2}, C^{2} \Pi$ and $D^{2} \Sigma^{+}$are formed in the photon absorption by NO in the wavelength range $230>\lambda>150 \mathrm{~nm}$. Other observed products are due to reactions of $\mathrm{NO}^{*}$. Pertinent processes are reaction of $\mathrm{NO}^{*}$ with $\mathrm{NO}$, predissociation (atom formation), reactive quenching and physical quenching. The first is important in laboratory studies but need not be considered for the photolysis of trace amounts of NO in air. (Mechanisms applicable to laboratory photolyses are given in section 3 a,b.)

The other processes are important for atmospheric photolysis of NO. Cieslik and Nicolet (w) have developed an overall photodissociation rate. The remarks that follow rely heavily on their discussion and on two recent reviews $(i, j)$ and the summary in (c).

Each state is considered separately. An estimate is made for an "effective initial quantum yield" of products (e.g. $0, \mathrm{~N}, \mathrm{NO}_{2}$ ). More precisely, these estimates are ratios: Products formed per No* disappearing by all paths. For each excited electronic state a vibrational-rotational level is reached that is strongly predissociated. (The evidence is either absence of higher levels in emission spectra or line broadening). All higher levels are assumed to dissociate to atoms either directly or via another electronic state. The main discussion is about the fate of lower levels. 
NO $\left(A^{2} \Sigma^{+}\right)$

This is the upper state for the $\vee$ bands $(X \rightarrow A)$. Vibrational levels $\mathrm{v}^{\prime}>4$ are predissociated. $\emptyset(0)=\emptyset(\mathrm{N})=1, \mathrm{v}^{\prime}>4$. For lower levels the only important atmospheric reaction partner is $0_{2}(s)$. ( $\mathrm{N}_{2}$ is 2000 fold less efficient and is ignored here). Quenching by $\mathrm{O}_{2}$ may be a chemical reaction, in analogy to $\mathrm{NO}$ and $\mathrm{CO}_{2}$ $(\mathrm{s}, \mathrm{k}, \mathrm{v})$. The leve $1 \mathrm{~A}(\mathrm{v}=0)$ is $1.017 \mathrm{ev}$ below the dissociation limit for the ground state (forming ground state atoms)

The minimum required steps are

$$
\begin{gathered}
\mathrm{NO}+\mathrm{h} \nu \rightarrow \mathrm{NO}\left(\mathrm{A}^{2} \Sigma^{+}, \mathrm{v}=0\right) \\
\mathrm{NO}\left(\mathrm{A}^{2} \Sigma^{+}\right) \rightarrow \mathrm{NO}+\mathrm{hv} \\
\mathrm{NO}\left(\mathrm{A}^{2} \Sigma^{+}\right)+\mathrm{O}_{2} \rightarrow \mathrm{NO}+\mathrm{O}_{2} \\
\rightarrow \mathrm{NO}_{2}+0 \\
\emptyset(0)=\emptyset\left(\mathrm{NO}_{2}\right) \sim \mathrm{k}_{4}\left[\mathrm{O}_{2}\right] /\left(\left(\mathrm{k}_{3}+\mathrm{k}_{4}\right)\left[\mathrm{O}_{2}\right]+\mathrm{k}_{2}\right)
\end{gathered}
$$

Reaction (4) is speculative. It has not been observed. $\emptyset$ can vary from zero to near 1 depending upon the value of $k_{4} / k_{3}$. We guess that $k_{4} / k_{3}>1$.

Rate constants are $k_{2}=5 \times 10^{6} s^{-1}$ (c) and $\left(k_{3}+k_{4}\right)=1.6 \times 10^{-10}$ $\mathrm{cm}^{3}$ molecule $\mathrm{s}^{-1}$ (s). At $20 \mathrm{~km}$ radiative 1 oss would be about $8 \%$ of the total but would increase in importance with increasing altitude. 
$\underline{\mathrm{NO}\left(\mathrm{B}^{2} \Pi\right)}$

This is the upper state for the $\beta$ bands $(X \rightarrow B)$. Emission has not been observed for $v^{\prime}>7$ (which lies close to the dissociation limit of $\mathrm{N} 0), \emptyset(0)=\emptyset(\mathrm{N})=1, \mathrm{v}^{\prime}>7$. Our knowledge of the photochemistry of this state is sketchy. We follow Preston and Cvetanovic (j) and suggest a behavior similar to that of $\mathrm{A}^{2} \Sigma^{+}$. $\underline{\mathrm{N} 0\left(\mathrm{C}^{2} \Pi\right)}$

This is the upper state of the bands $(X \rightarrow C)$. Emission from $\mathrm{v}^{\prime}>0$ has not been observed. $\emptyset(0)=\emptyset(\mathrm{N})=1, \mathrm{v}^{\prime}>0$. Emission has been observed from $v^{\prime}=0$, but even here some levels are predissociated.' This state has its minimum energy at approximately the dissociation limit for the $\mathrm{X}$ state. Cieslik and Nicolet (w) consider the $C$ state to be the most important contributor to the photodissociation process in the upper atmosphere.

A mechanism for photolysis in air that can be used to estimate a lower limit for the quantum yield is

$$
\begin{gathered}
\mathrm{NO}+\mathrm{h} \nu \rightarrow \mathrm{NO}\left(\mathrm{C}^{2} \Pi, \mathrm{v}=0\right) \\
\mathrm{NO}\left(\mathrm{C}^{2} \Pi\right) \rightarrow \mathrm{NO}+\mathrm{h} \nu\left(\text { to } \mathrm{X}^{2} \Pi \text { and } \mathrm{A}^{2} \Sigma^{+}\right) \\
\mathrm{NO}\left(\mathrm{C}^{2} \Pi\right) \rightarrow \mathrm{N}+\mathrm{O} \\
\mathrm{NO}\left(\mathrm{C}^{2} \Pi\right)+\mathrm{M} \rightarrow \text { loss of } \mathrm{NO}\left(\mathrm{C}^{2} \Pi\right)
\end{gathered}
$$




$$
\begin{gathered}
\emptyset(\mathrm{N})=\emptyset(0) \geq \mathrm{k}_{3} /\left(\mathrm{k}_{3}+\mathrm{k}_{2}+\mathrm{k}_{4}[\mathrm{M}]\right) \\
\geq 17 \times 10^{8} /\left(17 \times 10^{8}+9 \times 10^{7}+15 \times 10^{-10}[\mathrm{M}]\right) \\
\geq 1 /\left(1+0.8 \times 10^{-18}[\mathrm{M}]\right)
\end{gathered}
$$

Rate constants given in reference [c] have been used. These apply to $\mathrm{NO}\left(\mathrm{C}^{2} \Pi, \mathrm{v}=0\right)$ the level least likely to predissociate. The value for $k_{4}$ is for nitrogen. It is used here as an upper limit for physical quenching.

At $20 \mathrm{~km},[\mathrm{M}] \sim 2 \times 10^{18}$ molecules $\mathrm{cm}^{-3}$ and $\emptyset \geq 0.4$. This lower limit will increase with altitude. Reactive quenching by $\mathrm{O}_{2}$ (see remarks on $\mathrm{NO}\left(\mathrm{A}^{2} \Sigma^{+}\right)$) would also increase $\emptyset(0)$. $\underline{N O}\left(D^{2} \Sigma^{+}\right)$

This is the upperstate of the $\epsilon$ bands $(X \rightarrow D)$. It has approximately the same energy as $\mathrm{C}^{2} \Sigma^{+}$. However, the rate of predissociation is less than $1 / 5$ that of spontaneous emission:

$$
\begin{gathered}
\mathrm{NO}+\mathrm{h} \nu \rightarrow \mathrm{NO}\left(\mathrm{D}^{2} \Sigma^{+}\right) \\
\left.\mathrm{NO}\left(\mathrm{D}^{2} \Sigma^{+}\right) \rightarrow \mathrm{NO}+\mathrm{h} \nu(\text { to } \mathrm{X} \text { and } \mathrm{A})\right) \\
\mathrm{NO}\left(\mathrm{D}^{2} \Sigma^{+}\right) \rightarrow \mathrm{N}+\mathrm{O} \\
\mathrm{NO}\left(\mathrm{D}^{2} \Sigma^{+}\right)+\mathrm{N}_{2} \rightarrow \mathrm{NO}(\mathrm{X}) \\
\mathrm{NO}\left(\mathrm{D}^{2} \Sigma^{+}\right)+\mathrm{O}_{2} \rightarrow ? ?
\end{gathered}
$$


Ignoring reaction 5

$$
\begin{gathered}
\emptyset(0)=\emptyset(\mathrm{N})=\mathrm{k}_{3} /\left(\mathrm{k}_{3}+\mathrm{k}_{2}+\mathrm{k}_{4}\left[\mathrm{~N}_{2}\right]\right) \\
=\left(<8 \times 10^{6}\right) /\left(\left(<8 \times 10^{6}\right)+5 \times 10^{7}+3 \times 10^{-10}\left[\mathrm{~N}_{2}\right]\right) \\
<1 /\left(1+60+3.8 \times 10^{-17}\left[\mathrm{~N}_{2}\right]\right)
\end{gathered}
$$

Thus radiative loss and quenching are controlling. If, however, reaction 5 is efficient and is a chemical reaction, the quantum yields would be larger. See discussion of NO $\left(\mathrm{A}^{2} \Sigma^{+}\right)$.

$\underline{\mathrm{NO}\left(\mathrm{a}^{4} \mathrm{I}\right)}$

Unimportant. Gas phase absorption to this state is not observed. Excitation to this state probably is followed only by quenching to the ground state. 


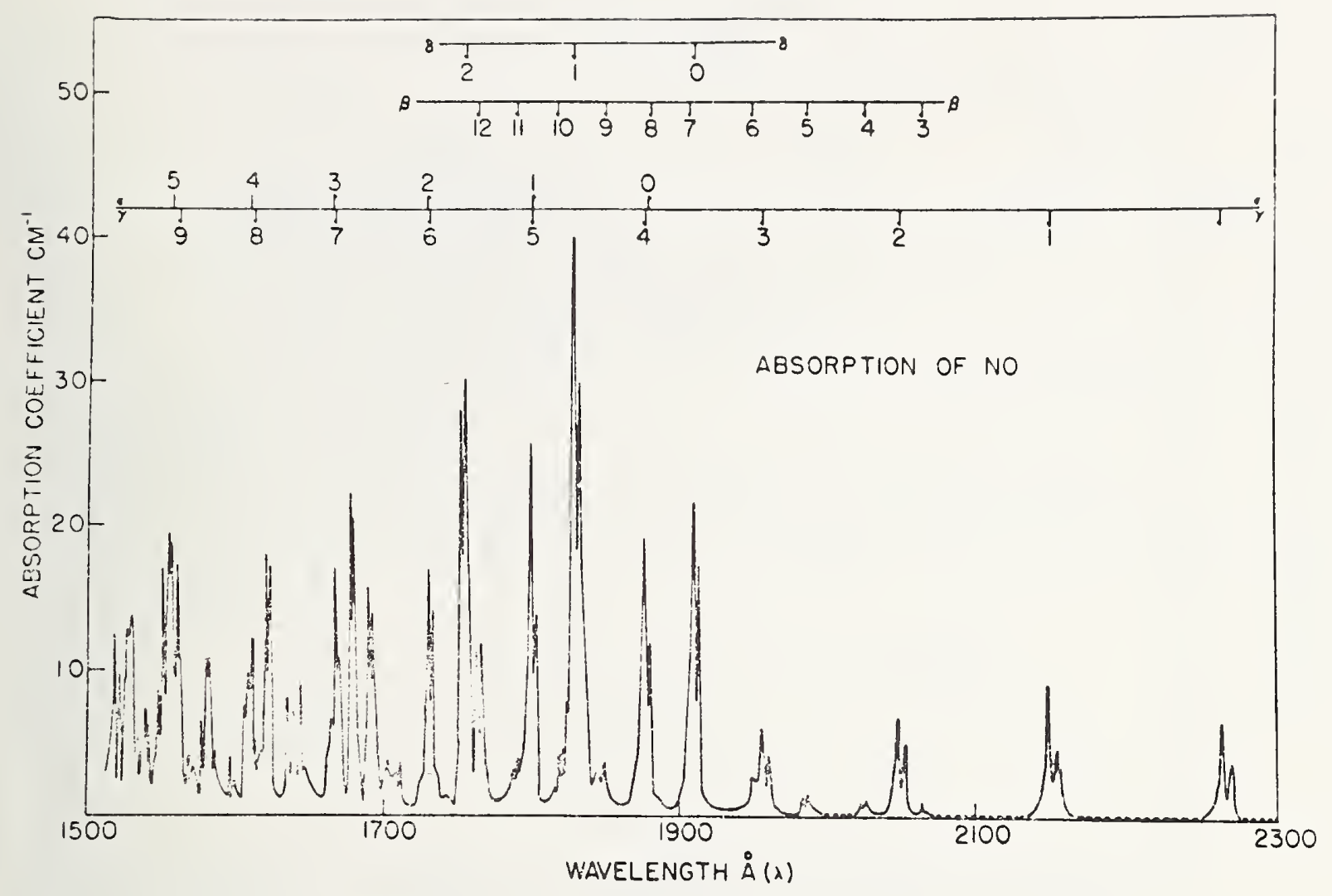

Fig. 1 Apparent absorption coefficient of NO in the wavelength region $150-230 \mathrm{~nm}$ in units of $\mathrm{cm}^{-1}$ (atm at $\left.273 \mathrm{~K}\right)^{-1}$ base e. The positions of the band heads for the $\delta, \beta, \varepsilon$, and $\gamma$ bands are indicated at the top. Band pass: $0.085 \mathrm{~nm}$. Data of F. Marmo. From Watanabe, Zelikoff, Inn, Geophysical Research Paper No. 21, AFCRL, June 1953. 


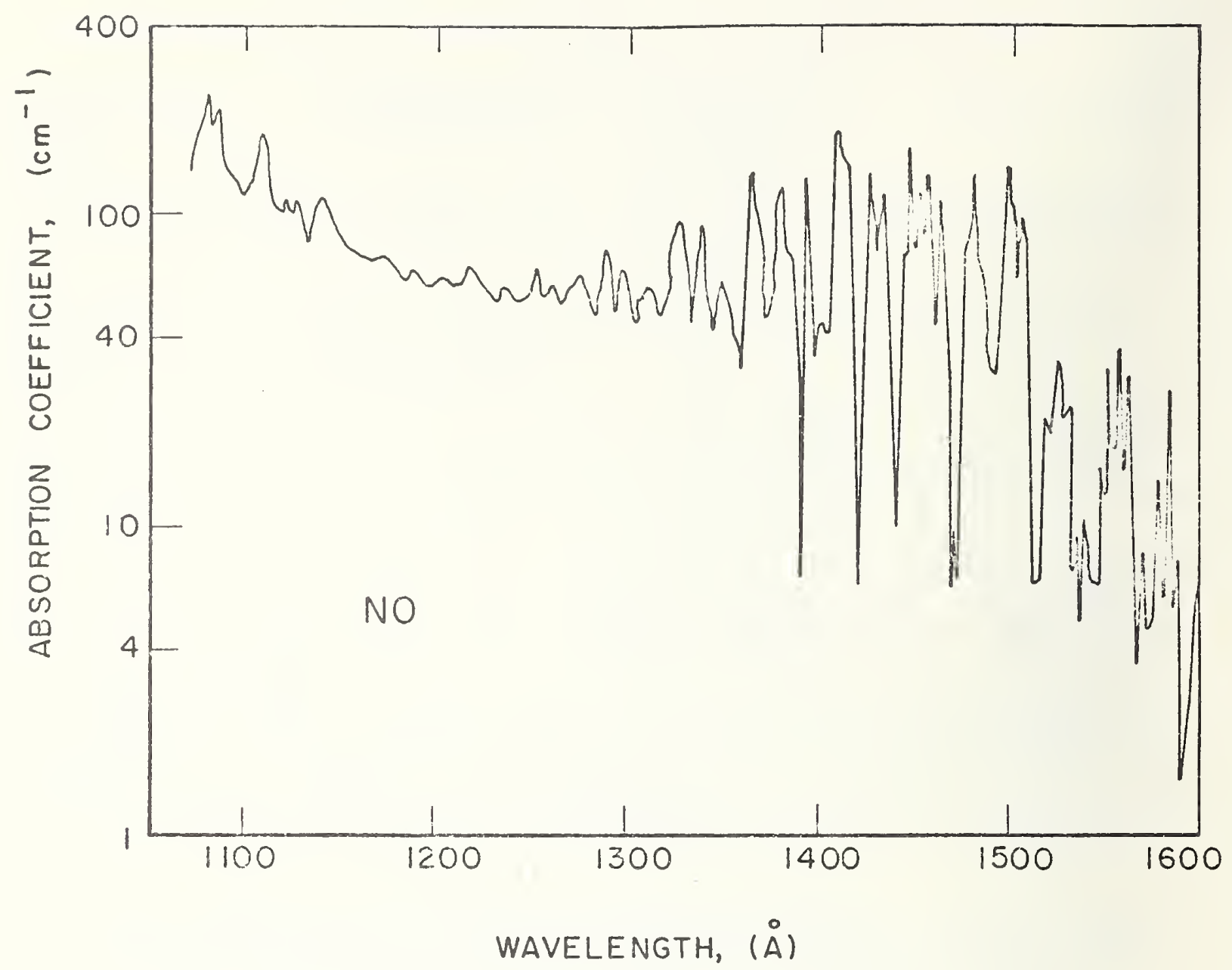

Fig. 2 Apparent absorption coefficient of NO in the wavelength region $110-160 \mathrm{~nm}$ in units of $\mathrm{cm}^{-1}$ (atm at $273 \mathrm{~K}$ ) ${ }^{-1}$ base e. Data of F. Marmo. From Watanabe, Zelikoff, Inn, Geophysical Research Paper No 21. AFC,RL. Tune 1952 


\section{$\underline{\text { References }}$}

a. D. D. Wagman et al, NBS Technical Note 270-3 (Jan. 1968).

b. C. E. Moore, NBS Circular 467, vol. 1 (1949).

c. A. B. Callear and M. J. Pilling, Trans. Far. Soc. 66, 1618 (1970).

d. F. F. Marmo, J. Opt. Soc. Am. 43, 1186 (1953).

e. B. A. Thompson, P. Harteck, and R. R. Reeves, Jr., J. Geophys . Res. 68, 6431 (1963).

f. K. Dressler and E. Miescher, Astrophys. J. 141, 1266 (1965).

g. K. Watanabe, F. M. Matsunaga, and H. Sakai, App1. Optics $\underline{6}, 391$ (1967)

h. R. D. Hudson, Rev. Geophys. Space Phys. 9, 305 (1971).

i. J. Heicklen and N. Cohen, Advances in Photochemistry 5, 157 (1968).

j. K. F. Preston and R. J. Cvetanovic, "Decomposition of Inorganic Oxides and Sulfides", in "Comprehensive Chemical Kinetics", ed. C. H. Bamford and C. F. H. Tipper (Elsevier Publishing Co. 1972) vo1. 4 pages 47-141.

k. J. Heicklen, J. Phys. Chem. 70, 2456 (1966).

1. J. Y. MacDonald, J. Chem. Soc. 1928, 1 (1928).

m. A. G. Leiga and H. A. Taylor, J. Chem. Phys. 42, 2107 (1965).

n. P. J. Flory and H. L. Johnston, J. Am. Chem. Soc. 57, 2461 (1935).

o. D. S. Sethi and H. A. Taylor, J. Chem. Phys. 48, 533 (1968).

p. H. Bubert and F. W. Froben, Chem. Phys. Lett. 8, 242 (1971).

q. M. Jeunehomme and A. B. F. Duncan, J. Chem. Phys. 41, 1692 (1964).

r. J. E. Hesser, J. Chem. Phys. 48, 2518 (1968). 
s. L. A. Melton and W. Klemperer, Planet, Space Sci. 20, 157 (1972).

t. I. M. Campbe11 and B. A. Thrush, J. Quant. Spectrosc. Radiat. Transfer $\underline{8}, 1571$ (1968).

u. F. Stuh 1 and H. Niki, Chem. Phys. Lett. I, 197 (1970).

v. N. Cohen and J. Heicklen, J. Phys. Chem. 71, 558 (1967).

w. S. Cieslik and M. Nicolet, Planet. Space Sci. 21, 925 (1973).

x. E. Miescher and F. Akermann, in "Spectroscopic Data relative to Diatomic Molecules", B. Rosen, editor. International Tables of Selected Constants (Pergamon Press, 1970), vol 17, p. 277.

y. H. P. Broida and M. Peyron, J. Chem. Phys. 32, 1068 (1960).

z. Ch. Jungen and E. Miescher, Can. J. Phys., 46987 (1968).

aa. G.W. Bethke, J. Chem. Phys. 31, 662 (1959).

bb. A. B. Callear and M. J. Pilling, Trans. Faraday Soc. 66, 1886 (1970).

cc. A. J. D. Farmer, V. Hasson and R. W. Nicholls, J. Quant. Spectrosc. Radiat. Transfer $\underline{12}, 627$ (1972).

dd. A. Pery-Thorne and F. Banfield, J. Phys. B., Atom. Molec. Phys. 3, 1011 (1970).

ee. G. V. Marr, Proc. Phys. Soc., 83, 293 (1964).

H. Okabe

D. Garvin

R. Hampson

July, 1973 


\section{Chemical Kinetics Data Survey}

The Combination Reaction of NO and 0

1. $\mathrm{NO}+\mathrm{O}\left({ }^{3} \mathrm{P}\right)+\mathrm{M} \rightarrow \mathrm{NO}_{2}+\mathrm{M}$

2. $\Delta \mathrm{H}_{298}^{\circ}=-306.2 \mathrm{~kJ} \mathrm{~mol}{ }^{-1}\left(-73.2 \mathrm{kcal} \mathrm{mol}^{-1}\right)$

3. $\underline{\text { Data }}$

a. The rate measurements on this reaction prior to July

1970 were compiled and reviewed by Baulch, Drysdale, and

Horne (b). The major investigations of the temperature

dependence of the reaction were performed using discharge

flow systems by Clyne and Thrush (c) over the range

212-293 K, and by Klein and Herron (d) over the range

300-505 K. The third body effect was studied extensively

by Kaufman and Kelso (e) at room temperature also using

a discharge flow system.

b. Recent measurements

\begin{tabular}{|c|c|c|c|}
\hline $\mathrm{k}_{1}\left(\mathrm{~cm}^{6}\right.$ molecule $\left.\mathrm{e}^{-2} \mathrm{~s}^{-1}\right)$ & $\underline{M}$ & $\mathrm{~T}$ & System \\
\hline $6.65 \times 10^{-32}$ & $\mathrm{He}$ & $300 \mathrm{~K}$ & $\begin{array}{l}\text { Pulsed vacuum-uv photolysis } \\
\text { of NO }(1-3.5 \text { torr) or of }\end{array}$ \\
\hline $15 \times 10^{-32}$ & NO & $300 \mathrm{~K}$ & $\begin{array}{l}\mathrm{O}_{2}(0.1 \text { torr }) \text { in presence of } \\
\mathrm{NO}(<0.3 \text { torr }) \text { and He } \\
(<31 \text { torr }) .0 \text { atom decay } \\
\text { rate monitored by chemiluminescent } \\
\text { reaction } 0+\mathrm{NO} \rightarrow \mathrm{NO}_{2}+\mathrm{h} \nu \\
\text { STUHL, NIKI } 1971 \text { (f) }\end{array}$ \\
\hline
\end{tabular}


$\mathrm{k}_{1}\left(\mathrm{~cm}^{6}\right.$ molecule $\mathrm{s}^{-2} \mathrm{~s}^{-1}$

$13.5 \times 10^{-32}$

$6.0 \times 10^{-32}$

$13.0 \times 10^{-32}$
$\underline{\mathrm{M}} \quad \underline{\mathrm{T}}$

Ar $\quad 300 \mathrm{~K}$

Ar $\quad 296$

Ar 241
System

Pulsed photolysis of $0_{2}$ (0.1 torr) at $147 \mathrm{~nm}$ in presence of NO (1-8 mtorr) and $\operatorname{Ar}$ ( 6 or 10 torr). 0 atom decay rate detected by resonance fluorescence. SLANGER, BLACK 1970 (g)

Pulsed photolysis of $\mathrm{O}_{2}$ (0.1 torr) at $147 \mathrm{~nm}$. in the presence of 0.1 torr NO and 10 torr Ar. Experiments primarily performed to measure rate constant for $\mathrm{O}+\mathrm{NO}_{2} \rightarrow \mathrm{NO}+\mathrm{O}_{2}$. SLANGER, WOOD, BLACK 1973 (h)

\section{Preferred values}

$\mathrm{k}=2.9 \times 10^{-33} \exp (940 / \mathrm{T}) \mathrm{cm}^{6}$ molecule $\mathrm{s}^{-1}, \mathrm{M}=0_{2}$

Temperature range: $200-500 \mathrm{~K}$.

Estimated error limit: $\pm 20 \%$ at $298 \mathrm{~K}, \pm 50 \%$ at other temperatures. $\mathrm{k}(298 \mathrm{~K})=6.8 \times 10^{-32} \mathrm{~cm}^{6}$ molecule $\mathrm{e}^{-2} \mathrm{~s}^{-1} \mathrm{M}=0_{2}$

$\mathrm{k}(220 \mathrm{~K})=2.1 \times 10^{-31} \mathrm{~cm}^{6}$ molecule $\mathrm{s}^{-2} \mathrm{M}=0_{2}$

Relative efficiencies for M:

$\mathrm{N}_{2}(1.4) ; 0_{2}(1) ; \operatorname{Ar}(1)$ 
5. $\quad \underline{\text { Remarks }}$

The recommended rate expression is that given by Baulch et al (b). The relative efficiency values are also from (b). This expression for $k$ (T) has been confirmed by the recent measurements of Stuhl and Niki at $300 \mathrm{~K}$ (f) and those of slanger, Wood, and Black at room temperature and at $241 \mathrm{~K}$ (h). The earlier measurement by slanger and Black (g) is apparently a factor of two high. The authors speculated that a fast secondary reaction between atomic oxygen and vibrationa1ly excited nitrogen dioxide produced in reaction (1) was the cause of the higher measured rate constant.

\section{$\underline{\text { References }}$}

(a) D. D. Wagman, W. H. Evans, V. B. Parker, I. Halow, S. M. Bailey, and R. H. Schumn, NBS Technical Note 270-3, (1968).

(b) D. L. Baulch, D. D. Drysdale, and D. G. Horne, "High Temperature Reaction Rate Data", Report No. 5 (1970), Dept. of Physical Chemistry, The University, Leeds, England.

(c) M. A. A. Clyne and B. A. Thrush, Disc. Faraday Soc. 33, 139 (1962) .

(d) F. S. Klein and J. T. Herron, J. Chem. Phys. 41, 1285 (1964).

(e) F. Kaufman and J. R. Kelso, Symp. Chemiluminescence, Durham, N. C. (1965). 
(f) F. Stuhl and H. Niki, J. Chem. Phys. 55, 3943 (1971).

(g) T. G. Slanger and G. Black, J. Chem. Phys. 53, 3717 (1970) .

(h) T. G. Slanger, B. J. Wood, and G. Black, Inter. J. Chem. Kinetics $\underline{5}, 615$ (1973).

R. E. Huie, J. T. Herron January, 1973 


\section{PHOTOCHEMISTRY OF $\mathrm{NO}_{2}$}

1. Primary Photochemical Transitions

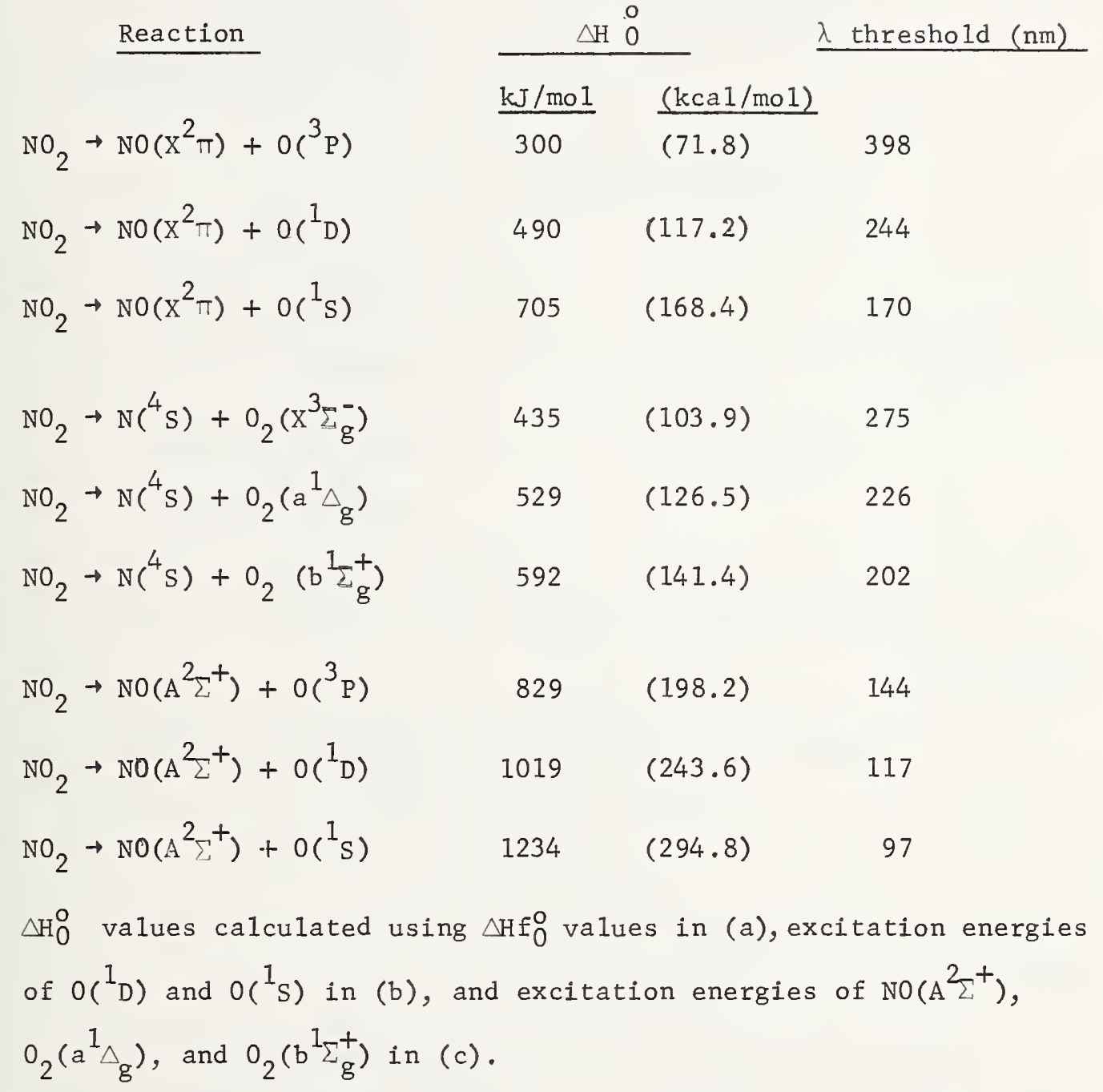


2.

2a. Absorption Coefficient

$240-500 \mathrm{~nm}$

400-700 nm

$108-270 \mathrm{~nm}$

405-515 nm
See Figure 1.

HALL, BLACET, 1952 (d)

DIXON, 1940 (e)

See Figures 2a, 2b, 2c, 2d

NAKAYAMA, KITAMURA,

WATANABE, 1959 (f)

WILKERSON, ERCOLI,

TOMPKINS, $1973(y)$

See Appendix for conversion factors for units of absorption coefficients.

2b. Overa11 Quantum yield for $0_{2}$ production, $\Phi\left(0_{2}\right)$ :

$$
\begin{gathered}
\mathrm{NO}_{2}+\mathrm{h} \nu \rightarrow \mathrm{NO}+\mathrm{O}\left({ }^{3} \mathrm{P}\right) \\
\mathrm{O}+\mathrm{NO}_{2} \rightarrow \mathrm{O}_{2}+\mathrm{NO}
\end{gathered}
$$

$\underline{\lambda(\mathrm{nm})} \underline{\underline{\left(\mathrm{O}_{2}\right)^{*}}}$

313

366

380

405

436

0.005

$*$ at $\mathrm{T}=296 \mathrm{~K}$

$$
0.97
$$

$\Phi\left(\mathrm{O}_{2}\right)$ measured. Equal to

$\emptyset(0)$ at low pressures. $\mathrm{P}\left(\mathrm{NO}_{2}\right)$

$=10$ torr. Values also given at $344,406,496$, and $566 \mathrm{~K}$ for $\lambda$

$=405 \mathrm{~nm}$. Non-zero value at $436 \mathrm{~nm}$ believed due to trace component of $405 \mathrm{~nm}$. PITTS, SHARP, CHAN, 1964 (h) 


\begin{tabular}{|c|c|c|}
\hline$\underline{\lambda(\mathrm{nm})}$ & $\Phi\left(\mathrm{O}_{2}\right)$ & \\
\hline 270 & 1.0 & Weighted average of results of \\
\hline 313 & 0.97 & four studies (1928-53). \\
\hline 366 & 0.92 & \\
\hline 405 & 0.36 & \\
\hline 436 & 0.00 & LEIGHTON, 1961 (i) \\
\hline$\underline{\lambda(\mathrm{nm})}$ & $\Phi\left(0_{2}\right)$ & \\
\hline 313 & 0.99 & Reassessment of data considered \\
\hline 366 & 0.96 & in (i) and those reported in \\
\hline 380 & 0.82 & \\
\hline 405 & 0.36 & \\
\hline 436 & $<0.005$ & $\begin{array}{l}\text { DEMERJIAN, KERR, CALVERT, } \\
1974 \text { (u) }\end{array}$ \\
\hline
\end{tabular}

2c. Overa11 quantum yield for NO production, $\Phi(N 0)$ :

$\begin{array}{lll}\frac{\Phi(\mathrm{nm})}{295-398} & \frac{\Phi(\mathrm{NO})}{2.0} & \text { Relative overa11 quantum yield } \\ 400 & 1.35 & \text { for production of } \mathrm{NO}, \Phi(\mathrm{NO}), \\ 405 & 0.64 & \text { measured. Values normalized } \\ 410 & 0.32 & \text { to values at } 313 \text { and } 366 \mathrm{~nm} \text { in } \\ 415 & 0.10 & \text { (i). P(NO }) \text { ) } 3 \text { torr. } \\ 420 & 0.07 & \text { Also, see Figure } 3 \\ 425 & 0.06 & \text { NOTE: Preliminary data } \\ 435 & 0.05 & \\ 490 & 0.03 & \end{array}$


3. Preferred values

a. Absorption coefficients

Use data in ref (d). See Fig. 1.
(See also special note under remarks)
Use data in ref (f). See Figures
2a, 2b, 2c, and $2 \mathrm{~d}$.

NOTE: Units of absorption coefficients

In Fig. 1, $\mathrm{k}$ is in units of $(\mathrm{mm} \mathrm{Hg} \text { at } 298 \mathrm{~K})^{-1} \mathrm{~cm}^{-1}$ (base 10)

In Fig. $2 a-d, k$ is in units of (atm at $273 \mathrm{~K})^{-1} \mathrm{~cm}^{-1}$ (base e)

See Appendix for table of conversion factors for units.

Absorption cross-sections averaged over $10 \mathrm{~nm}$ intervals:

\begin{tabular}{|c|c|c|c|}
\hline$\lambda(\mathrm{nm})$ & $\sigma\left(\mathrm{NO}_{2}\right)$ & $\lambda(\mathrm{nm})$ & $\sigma\left(\mathrm{NO}_{2}\right)$ \\
\hline 290 & $0.99 \times 10^{-19} \mathrm{~cm}^{2}$ & 400 & $6.53 \times 10^{-19} \mathrm{~cm}^{2}$ \\
\hline 300 & 1.41 & 410 & 6.38 \\
\hline 310 & 2.18 & 420 & 6.23 \\
\hline 320 & 2.98 & 430 & 5.88 \\
\hline 330 & 3.74 & 440 & 5.54 \\
\hline 340 & 4.54 & 450 & 5.20 \\
\hline 350 & 5.20 & 460 & 4.47 \\
\hline 360 & 5.69 & 470 & 4.05 \\
\hline 370 & 6.04 & 480 & 3.51 \\
\hline 380 & 6.23 & 490 & 3.06 \\
\hline 390 & 6.38 & 500 & 2.64 \\
\hline
\end{tabular}


b. Primary quantum yields for 0 atom formation, $\left.\phi(0)^{3} P\right)$ )

$\begin{array}{cc}\frac{\lambda(\mathrm{nm})}{295-398} & \frac{\emptyset\left(0\left(^{3} \mathrm{p}\right)\right)}{2} \\ 400 & 1.0 \\ 405 & 0.70 \\ 410 & 0.29 \\ 415 & 0.12 \\ 420 & 0.05 \\ 425 & 0.02 \\ 435 & 0.01 \\ 440 & 0.002 \\ >440 & 0.001\end{array}$

4. $\quad$ Remarks

a. Absorption coefficient

Ref. (d) Figure 1 also includes absorption coefficient data for $\mathrm{N}_{2} \mathrm{O}_{4}$. Resolution in spectrum that data are based on was $0.4 \mathrm{~nm}$. It is not possible to assess the reproducibility of these absorption coefficients. Values for $\mathrm{NO}_{2}$ and $\mathrm{N}_{2} \mathrm{O}_{4}$ were calculated from measured optical densities of two mixtures of $\mathrm{NO}_{2}$ and $\mathrm{N}_{2} \mathrm{O}_{4}$ having mole fractions of $\mathrm{N}_{2} \mathrm{O}_{4}$ equal to 0.20 and 0.57 . A third mixture, $\mathrm{x}_{\mathrm{N}_{2} \mathrm{O}_{4}}$ $=0.41$ gave good agreement. These measurements agree with those in (e) and (f) over the regions of wavelength overlap. 
The absorption coefficient data averaged over $10 \mathrm{~nm}$ intervals centered on the wavelength shown are derived from Table 14 of (i). They are based on data in (d). The entire table covers the wavelength range 290-700 $\mathrm{nm}$ and is based on (d) and (e).

The selection of the data in (d) is a tentative selection; work is in progress to measure the absorption coefficient over the photochemically active region $\lambda \lesssim 400 \mathrm{~nm}$ (aa).

Ref. (f) These are the only data for $\lambda<240 \mathrm{~nm}$. They have been critically reviewed in $(x)$.

Ref. (y) Measurements made on a $1.13 \% \mathrm{NO}_{2}$ in $\mathrm{N}_{2}$ mixture at

745 torr total pressure, $23.9^{\circ} \mathrm{C}, 10 \mathrm{~cm}$ path length. High resolution $(0.003 \mathrm{~nm})$. Results are consistent with the low-resolution data in (d) within the probable errors of the two studies.

Special Note Recent experiments (S. E. Novick, B. J. Howard, and W. Klemperer, J. Chem. Phys. 57, 5619 (1972) indicate the existence of the trimer $\mathrm{N}_{3} \mathrm{O}_{6}$ and possibly higher polymers in the gas phase. However, $\mathrm{N}_{3} \mathrm{O}_{6}$ will not be important in the atmosphere: the total $\left[\mathrm{NO}_{2}\right]$ is to sma11. If these recent experiments are verified, the experimental measurements of equilibrium constants and optical abscrption coefficients must be reanalyzed. Any effects of polymers will be more pronounced at low temperatures and at high pressures of $\mathrm{NO}_{2}$. The spectrum of $\mathrm{N}_{3} \mathrm{O}_{6}$ is not known.

It is our conjecture that the present absorption coefficients for $\mathrm{NO}_{2}$ are good $(\sim 15 \%)$ for $\lambda>300 \mathrm{~nm}$ but that the data for shorter wavelength regions may require revision. 
b. Primary quantum yield for 0 atom production, $\emptyset(0)$

Ref. (g) In order to deduce the value of $\emptyset(0)$ from the measured value of $\Phi(\mathrm{NO})$, it is necessary to assume a mechanism of photolysis of $\mathrm{NO}_{2}$. It is well established ( $\left.h, l\right)$ that for $\lambda<398 \mathrm{~nm}$ and at low conversions and low pressures, the mechanism is:

$$
\begin{aligned}
& \mathrm{NO}_{2}+\mathrm{h} v \rightarrow \mathrm{NO}+0 \\
& \mathrm{O}+\mathrm{NO}_{2} \rightarrow \mathrm{NO}+\mathrm{O}_{2}
\end{aligned}
$$

Isotopic scrambling experiments with ${ }^{36} 0_{2}$ showed the production of a free oxygen atom at $\lambda \leq 410 \mathrm{~nm}$. Similar results have been found by other workers (h, k-1). This confirms the above two-step mechanism for this wavelength range. For regions where this simple mechanism is applicable, $\emptyset(0)=(1 / 2) \times \Phi($ NO) . The preferred values of $\emptyset(0)$ were derived from the values of $\Phi(\mathrm{N} 0)$ in (g) according to the following scheme:

$$
\begin{array}{cc}
\lambda<415 \mathrm{~nm} & \emptyset(0)=(1 / 2) \times \Phi(\mathrm{N} 0) \\
\lambda>415 \mathrm{~nm} & \emptyset(0)=\exp \left[\left(\epsilon_{\lambda}-3.115\right) / 0.043\right]
\end{array}
$$

where $\varepsilon_{\lambda}=1239.8 / \lambda(\mathrm{nm})$ is the photon energy in ev, $3.115 \mathrm{ev}$ corresponds to $398 \mathrm{~nm}$, and $0.043 \mathrm{eV}$ is the e-folding parameter in region B in Figure 3.

The small non-zero values of $\Phi(N 0)$ at $\lambda \gtrsim 440 \mathrm{~nm}$ are suggested by the authors to result from reactions of $\mathrm{NO}_{2}^{*}$ to produce NO but not free 0 atoms. At this wavelength the photon energy is $0.3 \mathrm{eV}$ (i.e. approximately $12 \mathrm{kT}$ ) less than the energy required to dissociate $\mathrm{NO}_{2}$ into $\mathrm{NO}$ and $\mathrm{O}$. 


\section{Discussion}

This section summarizes interpretations of the photochemistry of $\mathrm{NO}_{2}$ and describes related work on excited states and fluorescence.

I. Primary Photochemical Processes in Various Wavelength Regions.

a) $\lambda<250 \mathrm{~nm}$

Wavelength threshold for $O\left({ }^{1} D\right)$ production is $244.1 \mathrm{~nm}$.

Lines are sharp in band at $249.1 \mathrm{~nm}$ and broadened in band at $245.9 \mathrm{~nm}$, while the bands at $244.7 \mathrm{~nm}$ and beyond are diffuse. Broadening of lines for $\lambda>$ threshold wavelength used as argument against correlation of absorption in this region with $O\left({ }^{1} D\right)$ formation (j).

Chemical evidence from photolysis at $\lambda=228.8 \mathrm{~nm}$ shows that of oxygen atoms produced, $40 \%$ are $0\left({ }^{1} D\right)(k 2)$. Photo-oxidation of butene-1 shows a change in mechanism between 228.1 and $253.7 \mathrm{~nm}$, suggesting $O\left({ }^{1} D\right)$ formation at $228.8 \mathrm{~nm}(\mathrm{k} 3)$.

If the broadened bands at $245.9 \mathrm{~nm}$ do correlate with formation of $O\left({ }^{1} D\right)$ then absorption from internally excited $\mathrm{N}_{2}$ may be involved.

b) $250<\lambda<398 \mathrm{~nm}$ $\left.\mathrm{NO}_{2} \rightarrow \mathrm{NO}\left(\mathrm{X}^{2} \pi\right)+\mathrm{O}^{3} \mathrm{P}\right)$ throughout this region. For discussion of complex mechanisms of photolysis see (h) and (l). 
Addition of high pressures of $\mathrm{N}_{2}$ reduces the total quantum yield in this wavelength region. This effect is partly due to changed rates of secondary reactions and partly due to quenching of the upper state formed in the photoabsorption act (cc). The latter (quenching) has a negligible effect on the primary process for pressures less than 1 atm. The former is significant at 1 atmosphere of $\mathrm{N}_{2}, \Phi(\mathrm{P}=0) / \Phi(\mathrm{P}) \sim 1.27$, due to the process:

$$
\begin{gathered}
0+\mathrm{NO}_{2}+\mathrm{M} \rightarrow \mathrm{NO}_{3}+\mathrm{M} \\
\mathrm{NO}_{3}+\mathrm{NO} \rightarrow 2 \mathrm{NO}_{2}
\end{gathered}
$$

competing with $\mathrm{O}+\mathrm{NO}_{2} \rightarrow \mathrm{O}_{2}+\mathrm{NO}$

c) $\lambda>398 \mathrm{~nm}$

Threshold for $0\left({ }^{3} \mathrm{P}\right)$ production is $398 \mathrm{~nm}$. Some residual oxygen atom production at Ionger wavelengths by absorption from internally excited $\mathrm{NO}_{2}(\mathrm{~h})$ or by collisionally induced dissociation of $\mathrm{NO}_{2}{ }^{*}(\mathrm{~g})$. Otherwise absorption in this region results in formation of $\mathrm{NO}_{2}{ }^{*}$ the dominant fate of which is fluorescence or collisional quenching. In presence of $\mathrm{O}_{2}, \mathrm{NO}_{2}{ }^{*}$ can undergo energy transfer to give $0_{2}\left({ }^{1} \triangle g\right)(z)$.

Under high resolution, lines in the absorption spectrum are sharp for $\lambda>397.9 \mathrm{~nm}$ and diffuse at shorter wavelength (m). This onset of diffuseness is in excellent agreement with the calculated wavelength threshold for $0\left({ }^{3} \mathrm{P}\right)$ production. This line spectrum of $\mathrm{NO}_{2}$ is very rich. Only a few bands have been analyzed (m). A. E. Douglas (private communication) has estimated that there may be 


$$
\mathrm{NO}_{2}+\mathrm{h \nu}
$$

100,000 lines in the visible region that may be observed with the high resolution available with a $10 \mathrm{~m}$ grating spectrograph. Even with this resolution many of the lines are blends.

The plot of absorption coefficient versus wavelength, Figure 1, has the appearance of lines superimposed on a "continuum". This background is not a true continum but is due to absorption in the wings of many lines. It is an intrinsic part of the spectrum and is not due to limitations of instrumenta 1 resolution.

A recent discussion of the photochemistry of $\mathrm{NO}_{2}$ is given in (dd) .

II. Excited States of $\mathrm{NO}_{2}$

a. Lifetime measurements from fluorescence.

Wavelength

Region (nm)

State

Note

Ref.

$400-600$

${ }^{2} \mathrm{~B}_{2}$ ?

$40-90$

1,3

$\mathrm{n}, \mathrm{o}$

$458-521$ 'B ${ }^{2}{ }^{2}$ '

451-460

${ }^{2} \mathrm{~B}_{1},{ }^{2} \mathrm{~B}_{2} \quad 62-75 \quad 4$

2,3

$\mathrm{p}$

4

(bb)

\section{Notes:}

1. Excitation primarily by $\mathrm{Hg}$ lines. Lifetime dependence upon exciting $\lambda$ both found ( $n$ ) and not found (o).

2. Excitation by laser lines. Fluorescence spectrum shows vibrational and rotational structure and continuum (p). 
3. The number of upper electronic states is in question. One mechanism is in (o3). A recent theoretical treatment of the potential energy diagram is in (q).

Discussions of the transitions in the absorption spectrum of $\mathrm{NO}_{2}$ are in (r) and (s).

4. This detailed study using a tunable dye laser shows a structure of lifetimes as a function of wavelength. The conclusion is that the shorter life times ( $\tau=40-60 \mu \mathrm{s}$ ) reported in the Iiterature are due to geometrical effects. Earlier experiments are discussed in detail.

b. Quenching of $\mathrm{NO}_{2}{ }^{*}\left({ }^{2} \mathrm{~B}_{2}\right)$ fluorescence by various gases $\mathrm{NO}_{2}: \lambda_{\mathrm{E}}=436 \mathrm{~nm}$ (exciting wavelength)
$\mathrm{NO}_{2}{ }^{*}: \lambda_{\mathrm{F}}=470 \mathrm{~nm}$ (fluorescence wavelength)

$\underline{\mathrm{M}}$

$\mathrm{N}_{2}$

$\mathrm{O}_{2}$

NO

$\mathrm{NO}_{2}$

$\mathrm{CO}_{2}$

$\mathrm{H}_{2} \mathrm{O}$

$$
\frac{\mathrm{a}_{\mathrm{M}}\left(\mathrm{cm}^{3} \text { molecule } \mathrm{e}^{-1}\right)}{3.4 \times 10^{-15}}
$$

3.7

6.2

7.7

8. 1

21
$\frac{k_{Q, M}\left(\mathrm{~cm}^{3} \text { molecule } \mathrm{s}^{-1}\right)}{0.62 \times 10^{-10}}$

0.67

1.1

1.4

1.5

3.8 
Notes:

The quenching constant $a_{m}$ is defined by the equation:

1. $a_{M}=k_{Q, M}{ }^{x} T_{\text {rad }}$ for the mechanism:

$$
\begin{array}{ll}
\mathrm{NO}_{2}{ }^{*} \rightarrow \mathrm{NO}_{2}+\mathrm{h \nu} & \mathrm{k}_{\mathrm{rad}}=1 / \mathrm{T}_{\mathrm{rad}} \\
\mathrm{NO}_{2}{ }^{*}+\mathrm{M} \rightarrow \mathrm{NO}_{2}+\mathrm{M} & \mathrm{k}_{\mathrm{Q}, \mathrm{M}}
\end{array}
$$

2. a $\left(\mathrm{NO}_{2}\right)$ from Table I of ref. (o3). Other values of $a_{M}$ based on this value and ratios of $a_{M}\left(\lambda_{E}=436 \mathrm{~nm}\right)$ in Table II of ref. $t$ and arguments therein that $\mathrm{a}(\mathrm{M}) / \mathrm{a}\left(\mathrm{NO}_{2}\right)$ is independent of $\lambda_{\mathrm{F}}$ and $\lambda_{\mathrm{E}}$. 3. $k_{Q, M}$ calc. from $a_{M}$ with $\tau_{\text {rad }}=5.5 \times 10^{-5} \mathrm{~s}$. (o3).

c. Fluorescence of $\mathrm{NO}_{2}$ in the atmosphere

Based on mechanism in note 1 of section b above, the fraction of $\mathrm{NO}_{2}^{*}$ fluorescing in the presence of quenching gas, $\mathrm{M}$, at concentration $[M]$ is given by:

$$
f_{\text {fluorescing }}=\left(1+\sum_{M} a_{M}[M]\right)^{-1}
$$

In one atmosphere of $\mathrm{N}_{2} \mathrm{f} \sim 1.2 \times 10^{-5}$ for excitation at $436.0 \mathrm{~nm}$ and fluorescence at $470.0 \mathrm{~nm}$.

Total fluorescence per unit volume in sunlight depends upon incident light flux, absorption coefficient, and $a_{M}$ all of which are functions of wavelengths. Data for the calculation not available. 


$$
\mathrm{NO}_{2}+\mathrm{in}
$$

d. Photochemistry of $\mathrm{NO}_{2}$ in Air

To a good first approximation the following mechanism controls the relative concentrations of $\mathrm{NO}_{2}, \mathrm{NO}, \mathrm{O}$, and $\mathrm{O}_{3}$ in a polluted atmosphere (i):

$$
\begin{array}{ll}
\mathrm{NO}_{2}+\mathrm{h} \nu \rightarrow \mathrm{NO}+0 & \mathrm{k}_{\mathrm{a}}=8.0 \times 10^{-3} \mathrm{~s}^{-1}(\mathrm{u}) \\
0+\mathrm{O}_{2}+\mathrm{M} \rightarrow \mathrm{O}_{3}+\mathrm{M} & \mathrm{k}_{2}=5.6 \times 10^{-34} \mathrm{~cm}^{-6} \text { molecule } \mathrm{s}^{-1}(\mathrm{v}) \\
\mathrm{O}_{3}+\mathrm{NO} \rightarrow \mathrm{NO}_{2}+\mathrm{O}_{2} & \mathrm{k}_{3}=1.6 \times 10^{-14} \mathrm{~cm}^{-3} \text { molecule } \mathrm{s}^{-1}(\mathrm{w})
\end{array}
$$

The specific rate of photodissociation of $\mathrm{NO}_{2}$ to give 0 atoms by absorption of solar radiation is denoted by $k_{a}$ after the notation in ref. (i).

These reactions are controlling because they are much faster than any other reactions and involving these species in the polluted atmosphere. They establish the following stationary-state concentration or intermediates:

$$
\begin{aligned}
{\left[\mathrm{O}_{\mathrm{ss}}\right.} & =\mathrm{k}_{\mathrm{a}}\left[\mathrm{NO}_{2}\right] / \mathrm{k}_{2}\left[\mathrm{O}_{2}\right][\mathrm{M}]=1.1 \times 10^{-7}\left[\mathrm{NO}_{2}\right] \\
{\left[\mathrm{O}_{3}\right]_{\mathrm{ss}} } & =\mathrm{k}_{\mathrm{a}}\left[\mathrm{NO}_{2}\right] / \mathrm{k}_{3}[\mathrm{NO}] \\
& =5 \times 10^{11} \times\left[\mathrm{NO}_{2}\right] /[\mathrm{NO}] \mathrm{molecule} / \mathrm{cm}^{3}
\end{aligned}
$$

These formulae may be used, as a first approximation, to estimate [0] and $\left[\mathrm{O}_{3}\right]$ at any instant for which measurements of $\left[\mathrm{NO}_{2}\right]$ and [NO] are available.

The lifetime of an oxygen atom in air at one atmosphere, $\tau(0)=1 / k_{2}\left[O_{2}\right][M]$, is $12 \mathrm{\mu sec}$. This mechanism conserves the sum $\left[\mathrm{NO}_{2}\right]+[\mathrm{NO}]$. It does not give the rate of input or of destruction of nitrogen oxides in the atmosphere. 


$$
\mathrm{NO}_{2}+\mathrm{h \nu}
$$

\section{$\underline{\text { References }}$}

a) D. D. Wagman et a1, NBS Technical Note 270-3 (Jan. 1968).

b) C. E. Moore, NBS Circular 467, vo1. 1 (1949).

c) G. Herzberg, "Molecular Spectra and Molecular Structure," vo1. II. D. Van Nostrand Co. Inc. (1950).

d) T. C. Hal1, Jr. and F. E. Blacet, J. Chem. Phys. 20, 1745 (1952).

e) J.K. Dixon, J. Chem. Phys. 8, 157 (1940).

f) T. Nakayama, M. Y. Kitamura, and K. Watanabe, J. Chem. Phys . 30, 1180 (1959).

g) I. T. N. Jones and K. D. Bayes, private communication. Results were also presented at the Tenth Informal Conference on Photochemistry, Sti1lwater, Oklahoma, May 1972.

h) J.N. Pitts, Jr., J.H. Sharp, and S. I. Chan, J. Chem. Phys . 40, 3655 (1964)。

i) P. A. Leighton, "Photochemistry of Air Pollution," Academic Press (1961).

j) G. Herzberg, "Molecular Spectra and Molecular Structure," vol. III D. Van Nostrand Co. Inc. (1967).

k) K. F. Preston and R. J. Cvetanovic, Can J. Chem. 44, 2445 (1966); J. Chem. Phys. 45, 2888 (1966); Ber. der Bunsenges fur physikalische Chemie $\underline{72}, 177$ (1968).

1) H. Ford, Can. J. Chem. 38, 1780 (1960). 
m) A. E. Douglas and K. P. Huber, Can. J. Phys. 43, 74 (1965).

1) S. E. Schwartz and H. S. Johnston, J. Chem. Phys. 51, 1286 (1969).

2) P. B. Sackett and J. T. Yardley, Chem. Phys. Lettr. $\underline{6}$, 323 (1970).

o) 1) D. Neuberger and A. B. F. Duncan, J. Chem. Phys. 22, 1693 (1954).

2) K. Sakurai and G. Capelle, J. Chem. Phys. 53, 3764 (1970).

3) L. F. Keyser, S. Z. Levine, and F. Kaufman, J. Chem. Phys. 54, 355 (1971).

p) K. Sakurai and H. P. Broida, J. Chem. Phys. 50, 2404 (1969).

q) R. A. Gangi and L. Burne11e, J. Chem. Phys. 55, 843 (1971).

r) R. A. Gangi and L. Burnelle, J. Chem. Phys. 55, 853 (1971).

s) G. E. Busch and K. R. Wilson, J. Chem. Phys. 56, 3638 (1972).

t) G. H. Myers, D. M. Silver, and F. Kaufman, J. Chem. Phys. 44, $718(1966)$

u) Demerjian, K. L., Kerr, J.A., and Calvert, J. G., "The Mechanism of Photochemical Smog Formation," To appear in Adv. in Environmental Sci. and Technology, J. N. Pitts, Jr., and R. L. Metcalf editors, Wiley-Interscience (Vol. 4, 1974).

v) R. E. Huie, J. T. Herron, and D. D. Davis, J. Phys. Chem. 76, 2653 (1972).

w) R. F. Hampson, ed. NBS Report 10828 (Apri1 1972).

x) R. D. Hudson, Rev. Geophys. Space Phys. 9, 305 (1971). 
y) Wilkerson, T. D., Ercoli, B., and Tomkins, F. S. "Absorption Spectra of Atmospheric Gases" University of Maryland and Argonne National Laboratory Report to Stanford Research Institute (January, 1973). Data available from T. D. Wilkerson, Institute for Fluid Dynamics and Applied Mathematics, University of Maryland, College Park, Maryland 20742 .

z) I. T. N. Jones and K. D. Bayes, Chem. Phys. Lettrs 11 , 163 (1971).

aa) A. M. Bass and A. H. Laufer, Physical Chemistry Division, National Bureau of Standards (private communication).

bb) P. B. Sackett and J. T. Yardley, J. Chem. Phys. 57, 152 (1972).

cc) H. Gaedtke, H. Hippler and J. Troe, Chem. Phys. Lettrs $\underline{16}$, 177 (1972).

dd) K. F. Preston and R. J. Cvetanovic, "Decomposition of Inorganfe Oxides and Sulfides", in "Comprehensive Chemical Kinetics," ed. C. H. Bassford and C. F. H. Tipper, Elsevier Publishing Co (1972) vol. 4 pages 47-141.

R. F. Hampson

D. Garvin

January, 1973 


$$
\mathrm{NO}_{2}+\mathrm{hv}
$$

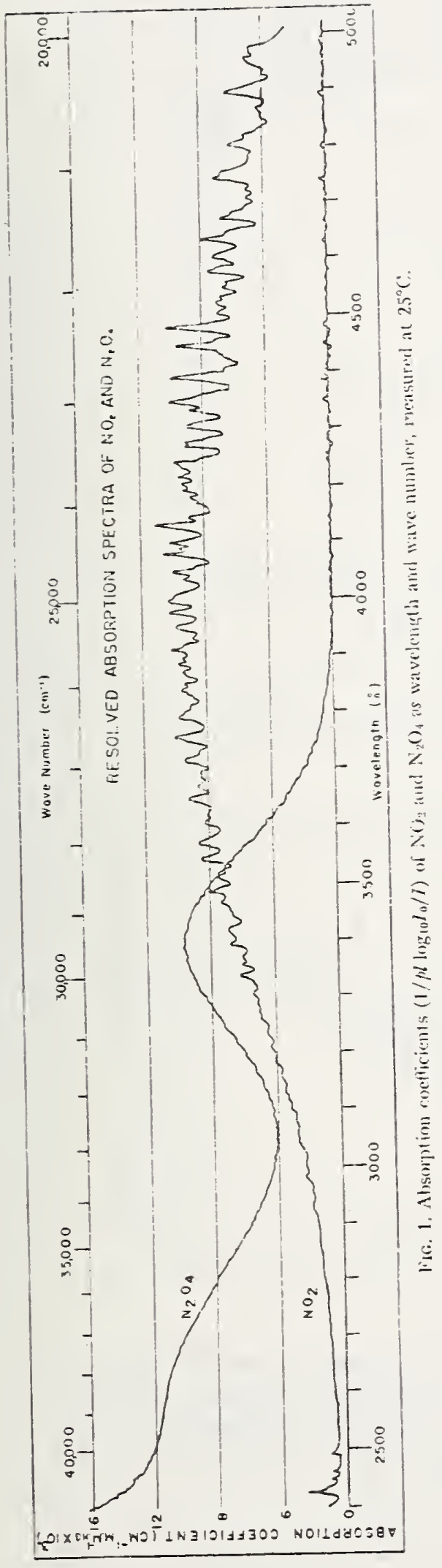

Figure 1.

Absorption coefficients

$\mathrm{k}=(1 / \mathrm{p} \ell) \log _{10}(\mathrm{Io} / \mathrm{I})$

$\mathrm{NO}_{2}$ and $\mathrm{N}_{2} \mathrm{O}_{4}$ at $25 \mathrm{C}$. where

$\mathrm{p}$ is the pressure in torr

at $25 \mathrm{C}$ and $l$ is the path

length in $\mathrm{cm}$.

HALL, BLACET, 1952 (d)

(reprinted with consent of authors) 


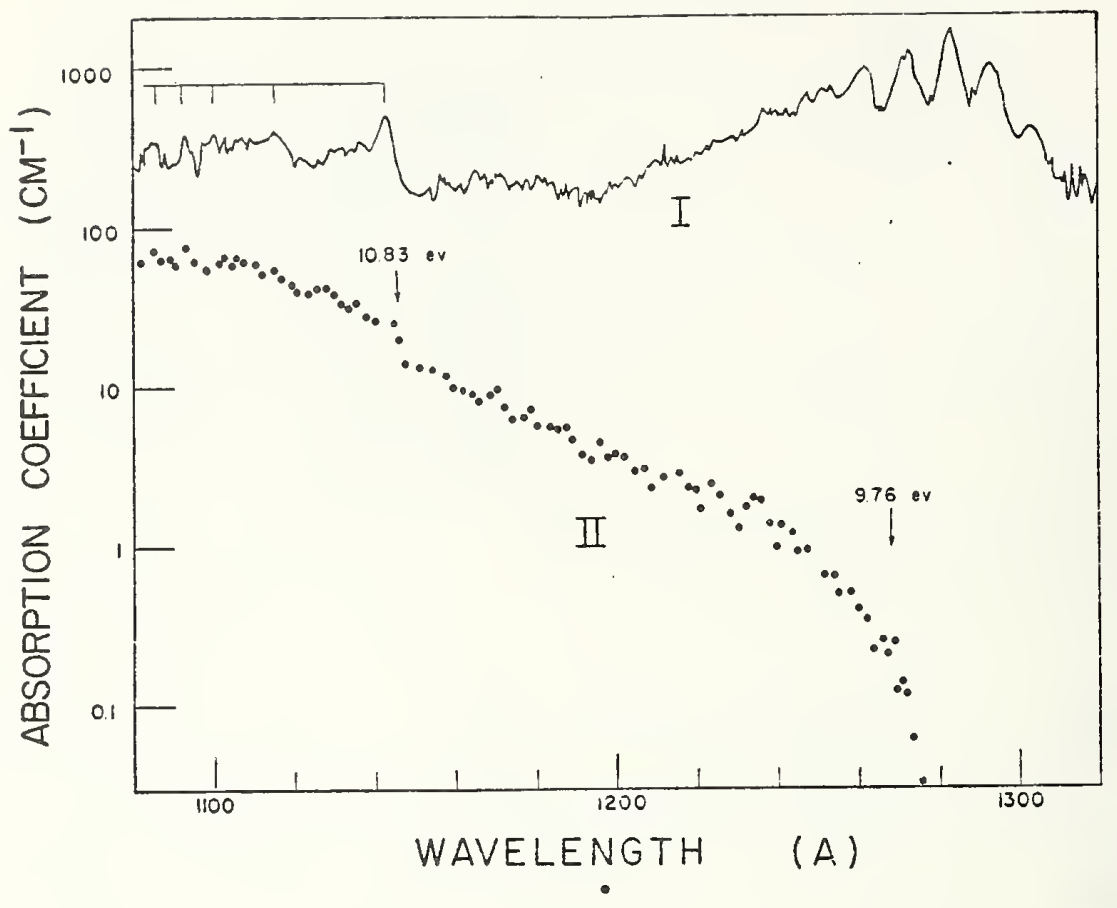

Fig. 2a. Absorption coefficient (I) and ionization coefficient (II) of $\mathrm{NO}_{2}$ in the region $108-130 \mathrm{~nm}$.

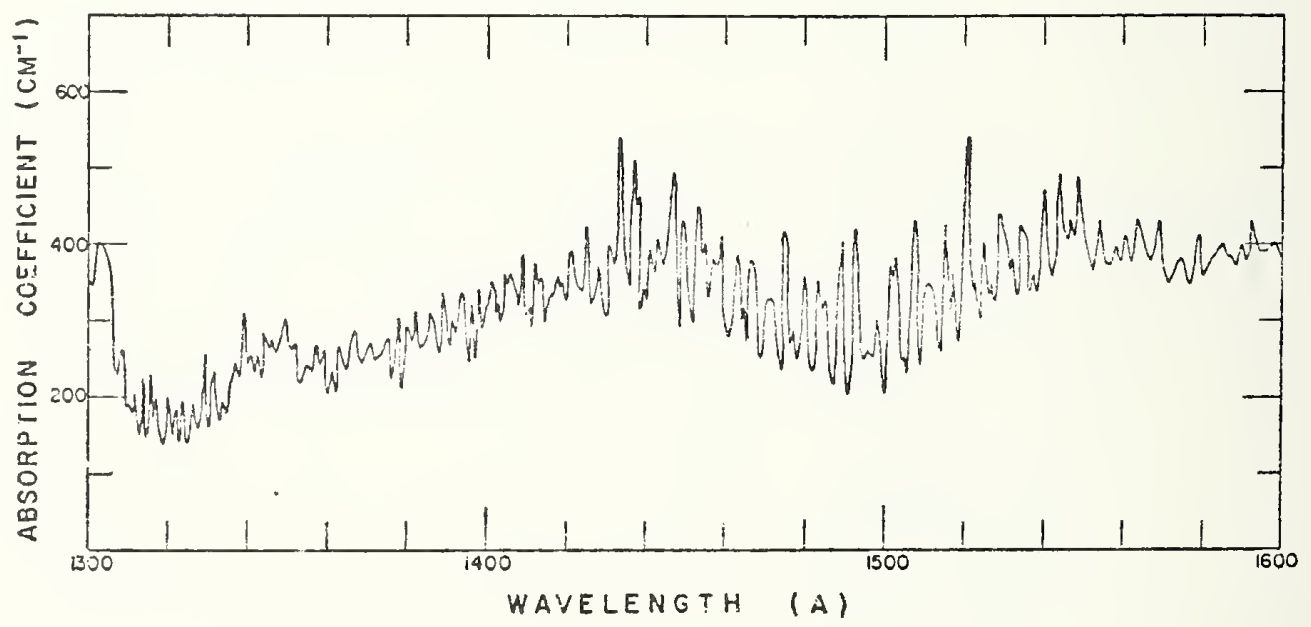

Fig. 2b. Absorption coefficient of $\mathrm{NO}_{2}$ in the region 130-160 $\mathrm{nm}$. NOTE: In Fig. 2a-d, the absorption coefficient, $k$, is defined as: $\bar{k}=(I / l) \log _{e}\left(I_{0} / I\right)$ where $l$, in $\mathrm{cm}$., is the layer thickness of the absorbing gas reduced to $273 \mathrm{~K}$ and $1 \mathrm{~atm}$ pressure. 


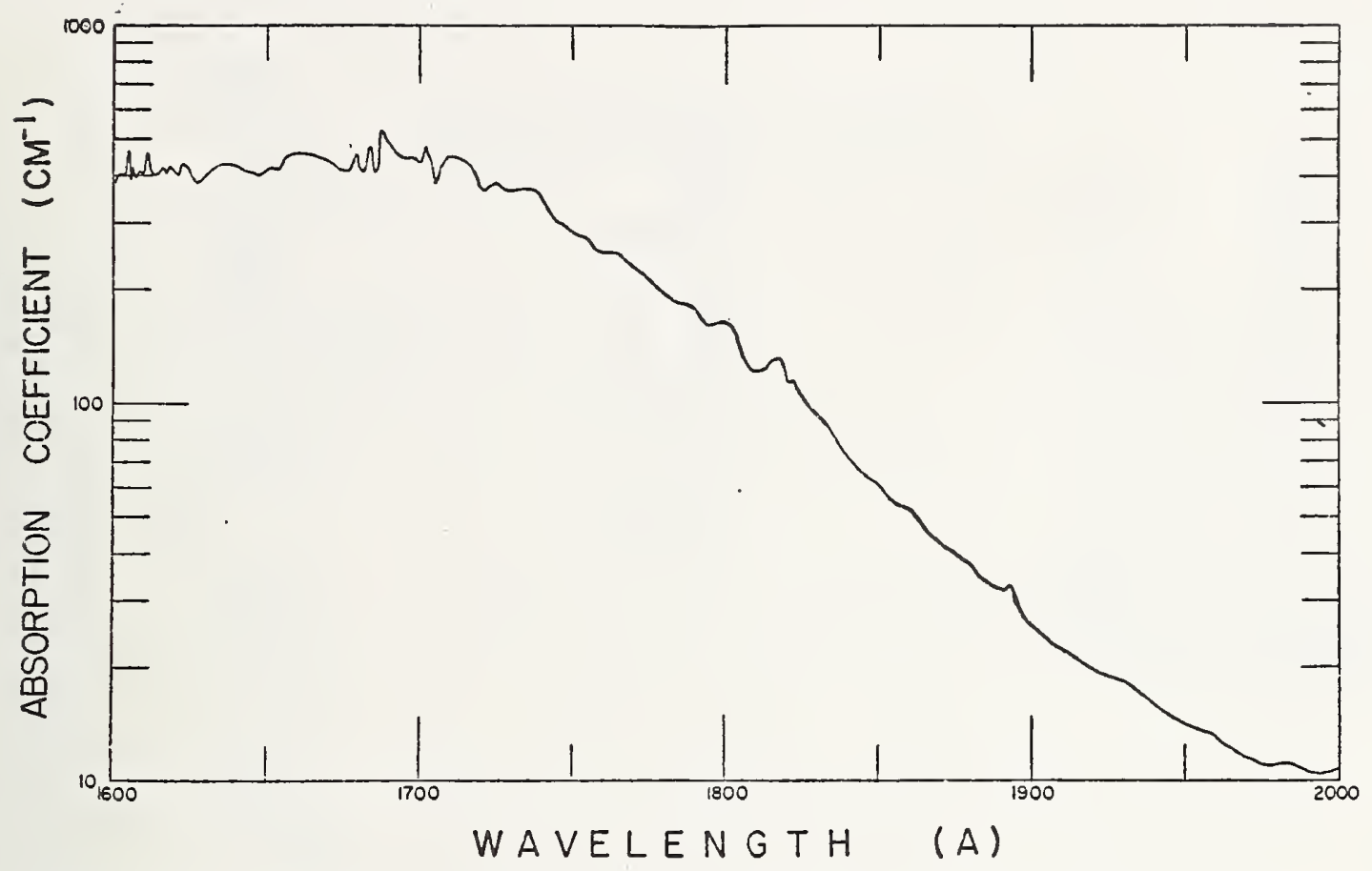

Fig. 2c. Absorption coefficient of $\mathrm{NO}_{2}$ in the region 160-200 nm.

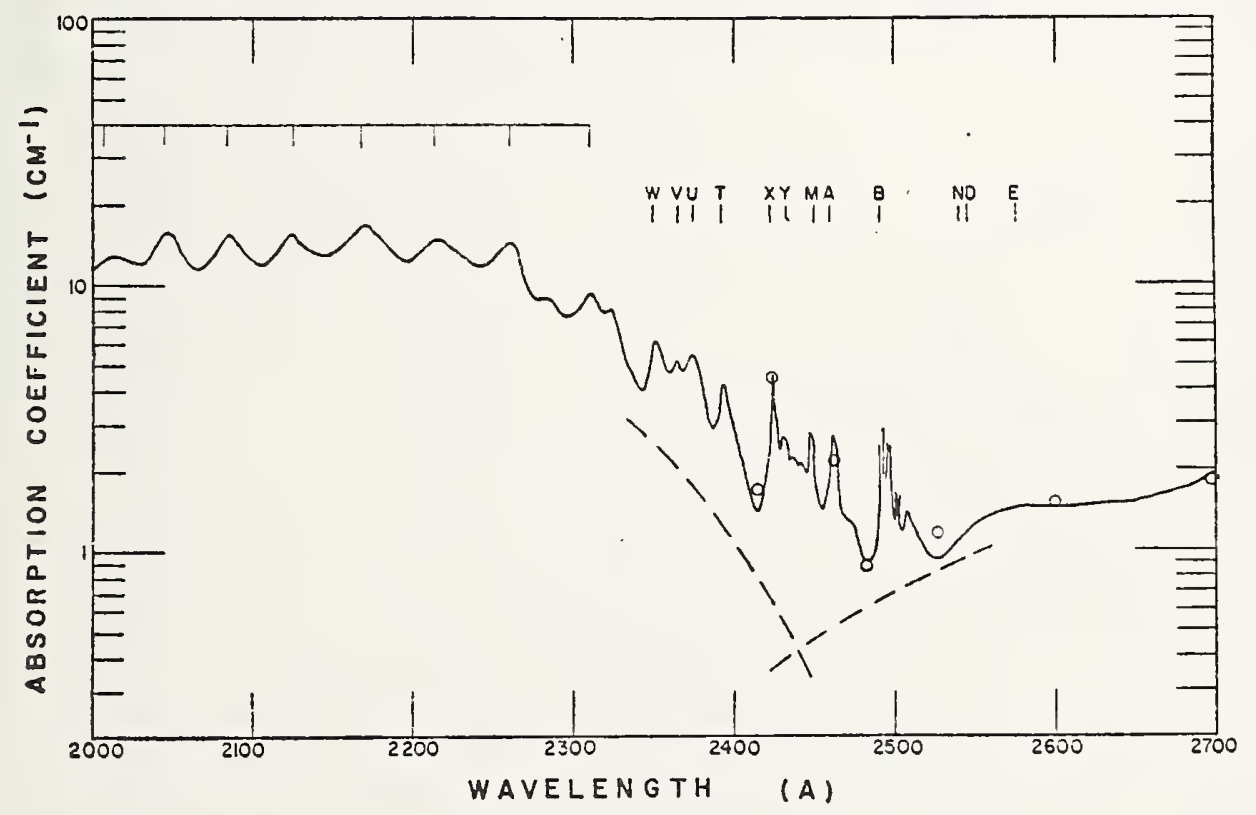

Fig. 2d. Absorption coefficient of $\mathrm{NO}_{2}$ in the region 200-270 nm. Dashed curves are suggested continua, and circles are some values by Hall and Blacet.

NAKAYAMA, KITAMURA, WATANABE, 1959 (f)

NOTE: In Fig. 2a-d, the absorption coefficient, $k$, is defined as: $\mathrm{k}=(1 / \ell) \log _{e}\left(I_{0} / I\right)$ where $\theta$, in $\mathrm{cm}$, , is the layer thickness of the absorbing gas reduced to $273 \mathrm{~K}$ and 1 atm pressure.

(Figures 2a-d reprinted with permission of American Institute of Physics) 
崖苛

㟧萿 0 范

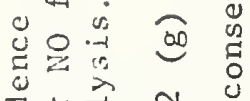

गु

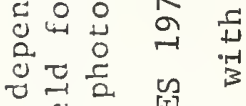

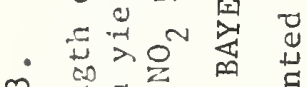

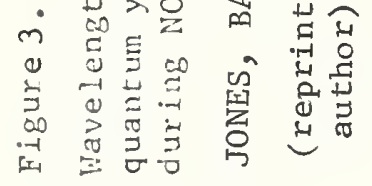
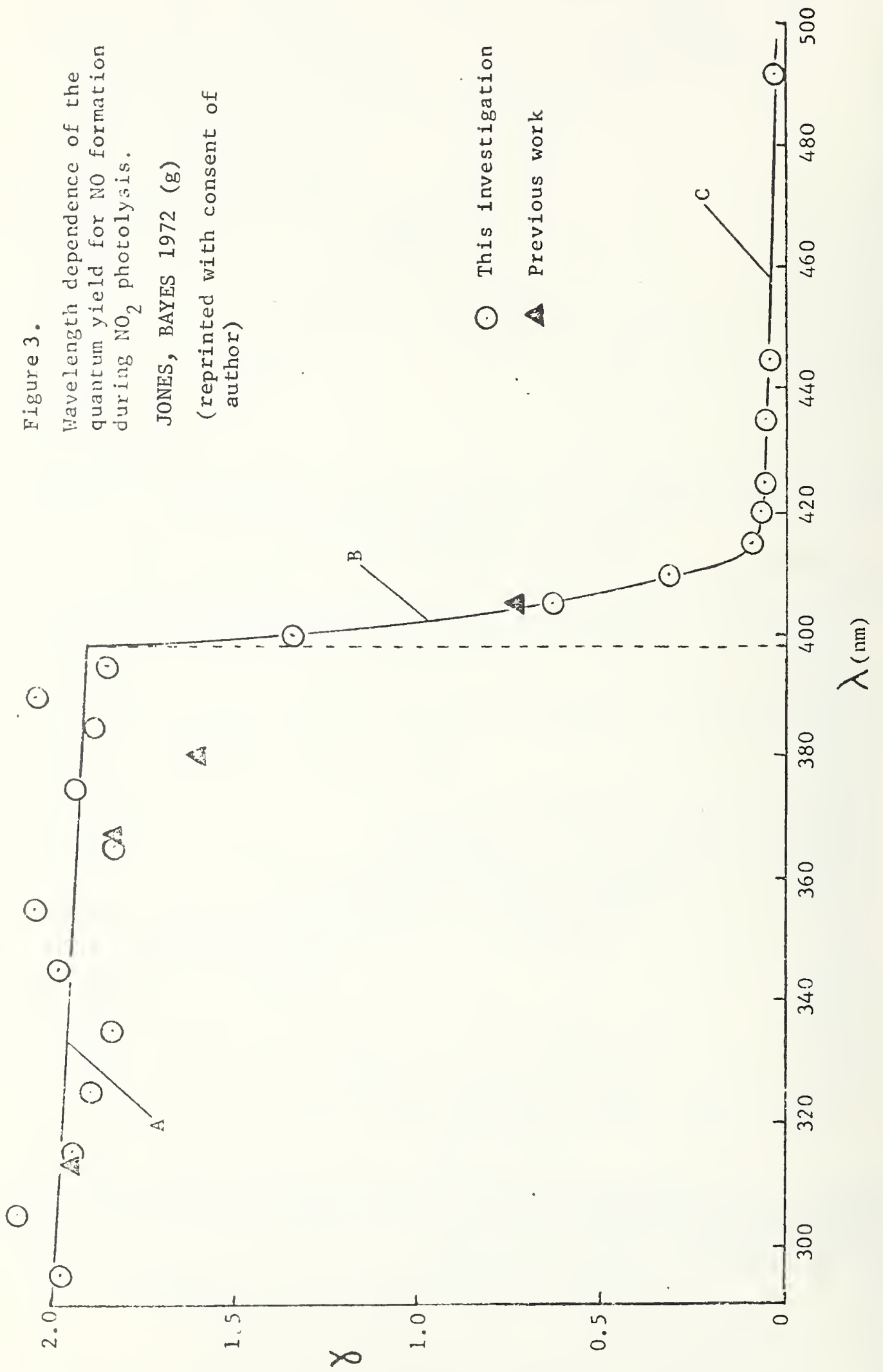


\section{Chemical Kinetics Data Survey}

The Bimolecular Reaction between $\mathrm{NO}_{2}$ and $\mathrm{O}\left({ }^{3} \mathrm{P}\right)$

1. $\left.\mathrm{NO}_{2}+\mathrm{O}^{3} \mathrm{P}\right) \rightarrow \mathrm{NO}+\mathrm{O}_{2}$

2. $\Delta \mathrm{H}_{298}^{\circ}=-192 \mathrm{~kJ} \mathrm{~mol}\left(-45.9 \mathrm{kcal} \mathrm{mol}^{-1}\right)$

3. Data

a. Prior to the review of Baulch, Drysdale, and Horne (b), dated July, 1970, this reaction had been studied over the temperature range $278-543 \mathrm{~K}$ in discharge flow systems, at $300 \mathrm{~K}$ in $\mathrm{flash}$ photolysis-flow systems, and at 298 and $410 \mathrm{~K}$ in a static flash photolysis system. Details are given in (b). Baulch et. al. recommended the expression $\mathrm{k}_{1}=1.7 \times 10^{-11} \exp (-300 / \mathrm{T}) \mathrm{cm}^{3}$ molecule $\mathrm{s}^{-1}$ over the temperature range $280-550 \mathrm{~K}$.

\section{b. Recent measurements:}

$\underline{k_{1}\left(\mathrm{~cm}^{3} \text { molecule } e^{-1} \mathrm{~s}^{-1}\right)} \quad \underline{\mathrm{T}(\mathrm{K})}$

\section{System}

$4.4 \times 10^{-12}$

300

Flash photolysis of NO (0.15 tor $r)$

in presence of $\mathrm{NO}_{2}(1-6$ mtorr $)$ and

He (10torr). 0 atom decay monitored

by chemiluminescent reaction

$\mathrm{O}+\mathrm{NO} \rightarrow \mathrm{NO}_{2}+\mathrm{h} \nu$.

STUHL, NIKI 1970 (c). 


$$
\mathrm{NO}_{2}+\mathrm{O}
$$

$6.1 \times 10^{-12}$

298

$9.12 \times 10^{-12}$

$230-339$

296

240

$k_{1} / k_{2}[M]=5.5$

where $\mathrm{k}_{2}: \mathrm{NO}+\mathrm{O}+\mathrm{M} \rightarrow \mathrm{NO}_{2}+\mathrm{M}$ and $[M]=1$ atm $N_{2}, 297 \mathrm{~K}$.
Discharge flow system. 0 atoms

formed from $\mathrm{N}+$ NO reaction.

$\left[\mathrm{NO}_{2}\right]=0.1-1.3$ mtorr. $[0]$ followed

by resonance fluorescence. Total pressure $=1.3$ torr. CLYNE, CRUSE 1972 (d).

Flash photolysis of $\mathrm{O}_{2}$ ( 1 torr) in presence of $\mathrm{NO}_{2}$ (1-7 mtorr) and

5 torr diluent $\left(\mathrm{N}_{2}, \mathrm{Ar}\right) \cdot[0]$ followed

by resonance fluorescence.

DAVIS, HERRON, HUIE 1973 (e).
$9.3 \times 10^{-12}$

$10.5 \times 10^{-12}$
Flash photolysis of $0_{2}$ ( 0.1 torr) in

presence of NO ( 0.1 torr), Ar (10 torr)

and $\mathrm{NO}_{2}(0.2-2$ mtorr). 0 atom decay

monitored by chemiluminescent reaction

$0+\mathrm{NO} \rightarrow \mathrm{NO}_{2}+h_{\Downarrow}$. Flow system.

SLANGER, WOOD, BLACK 1973 (f).

Photolysis of $\mathrm{NO}_{2} \cdot\left[\mathrm{NO}_{2}\right]$ and

$\left[\mathrm{N}_{2} \mathrm{O}_{5}\right]$ followed by long path I. R.

absorption. Molecular modulation

spectrum of $\mathrm{NO}_{2}$ measured.

HARKER, JOHNSTON, $1973(\mathrm{~g})$. 
$k_{1} / k_{3}[M]=9.2 \times 10^{2}$

where $\mathrm{k}_{3}: 0+\mathrm{O}_{2}+\mathrm{M} \rightarrow$

$\mathrm{O}_{3}+\mathrm{M}$ and $[\mathrm{M}]=1$ atm air

$298 \mathrm{~K}$
Photolysis of $\mathrm{NO}_{2}(1-100 \mathrm{ppm})$ in

air studied using $\mathrm{NO} / \mathrm{O}_{3}$

chemiluminescence detectors.

STEDMAN, NIKI, 1972 (h).

4. Recommended rate:

$k=9.1 \times 10^{-12} \mathrm{~cm}^{3}$ molecule $\mathrm{e}^{-1} \mathrm{~s}^{-1}$

Temperature range 220-500 K

Estimated error limits: $\pm 20 \%$

5. Remarks:

The rate expression recommended by Baulch, et al (b) was based on the data of Westenberg and de Haas ( $k$ ), Klein and Herron (1), and Smith (m). In the flash photolysis experiments of Smith (m), $k_{1}$ and $k_{4}(0+1$-butene $\rightarrow$ products $)$ were each measured relative to $k_{5}$ $\left(0+\mathrm{CS}_{2} \rightarrow \mathrm{CO}+\mathrm{S} 0\right)$. The absolute value of $\mathrm{k}_{5}$ was also measured. The value of $k_{1}$ reported was equal to $\left(k_{1} / k_{5}\right) \times k_{5}$. Alternatively, one can derive the value of $\left(k_{1} / k_{4}\right)$ from the reported values of $\left(k_{1} / k_{5}\right)$ and $\left(k_{4} / k_{5}\right)$ and then combine this ratio with the value of $k_{4}$ in ref (n) to give the value of $k_{1}$ to be $7.2 \times 10^{-12} \mathrm{~cm}^{3}$ molecule $\mathrm{s}^{-1}$ at $298 \mathrm{~K}$ and $9.2 \times 10^{-12} \mathrm{~cm}^{3}$ molecule $\mathrm{s}^{-1}$ at $410 \mathrm{~K}$. These values agree with the present recommended rate within the stated experimental uncertainty $( \pm 30 \%)$ in ref $(m)$. In the experiments of Klein and Herron (1), performed using a discharge flow system coupled to a mass spectrometer, a sudden decrease in the measured rate constant was 
observed at temperatures below $260 \mathrm{k}$, indicating that some phenomenon was complicating the system. If this complication existed unrecognized at the high temperatures used in the kinetic analysis, this could explain the reported lower values of the rate constant. The data of Westenberg and de Haas scatter considerably, but show little apparent temperature dependence. A simple average of the data gives $k_{1}=8.1 \times 10^{-12} \mathrm{~cm}^{3}$ molecule $\mathrm{s}^{-1}$, which is within $15 \%$ of the recommended value.

Since the review by Baulch, et al (b) there have been several investigations of reaction (1). Stuhl and Niki (c) and Clyne and Cruse (d) obtained values in reasonable agreement with the recommended value of Baulch et al (b). Davis, Herron, and Huie (e), however, obtained a higher rate constant which also showed no temperature dependence. Slanger, Wood, and Black (f) confirmed this value using an experimental technique similar to that of Stuhl and Niki (c). The ratio $k_{1} / k_{2}(M)$ in $(g)$ when combined with the value $9.5 \times 10^{-32} \mathrm{~cm}^{6}$ molecule $\mathrm{s}^{-1}$ recommended in this report for $\mathrm{k}_{2}\left(\mathrm{NO}+\mathrm{O}+\mathrm{N}_{2} \rightarrow \mathrm{NO}_{2}+\mathrm{N}_{2}\right)$ (see separate data sheet on $\mathrm{NO}+\mathrm{O}+\mathrm{M}$ ) gives a value of $k_{1}=12.8 \times 10^{-12} \mathrm{~cm}^{3}$ molecule $\mathrm{s}^{-1}$. The ratio $k_{1} / k_{3}[M]$ in (h) when combined with the values for $k_{3}\left(0+0_{2}+M\right.$ $\left.\rightarrow 0_{3}+M\right)$ in (i) and $(j)$ gives a value of $k_{1}=13.1 \times 10^{-12} \mathrm{~cm}^{3}$ molecule ${ }^{-1} \mathrm{~s}^{-1}$. These recent results from $\mathrm{NO}_{2}$ photolytic systems $(g, h)$ confirm earlier results on similar systems $(o, p)$. 


$$
\mathrm{NO}_{2}+\mathrm{O}
$$

Since the measurements of Davis, et $\underline{1}$ form the most extensive data set, and since these data seem to be supported by the most recent work, we have chosen the rate constant reported in that work as the recommended value.

A theoretical calculation using the bond energy-bond order (BEBO) method has been made for reaction 1 (q). An activation energy of about $12.5 \mathrm{~kJ} / \mathrm{mol}$ is predicted - at variance with the zero temperature dependence preferred here.

\section{$\underline{\text { References }}$}

(a) D. D. Wagman, et a1, NBS Technical Note 270-3 (Jan. 1968).

(b) D. L. Baulch, D. D. Drysdale, and D. G. Horne, "High Temperature Reaction Rate Data", Report No. 5 (1970), Dept. of Physical Chemistry, The University, Leeds, England.

(c) F. Stuh 1 and H. Niki, Chem. Phys. Letters 7, 197 (1970).

(d) M. A. A. Clyne and H. W. Cruse, J. Chem. Soc. Faraday Trans. II $\underline{68}, 1281$ (1972).

(e) D. D. Davis, J. T. Herron, and R. E. Huie, J. Chem. Phys., 58, $530(1973)$.

(f) T. G. Slanger, B. J. Wood, and G. Black, Typescript, Stanford Research Institute (1973).

(g) A. Harker and H. S. Johnston, J. Phys. Chem. 77, 1153 (1973). 


$$
\mathrm{NO}_{2}+\mathrm{O}
$$

(h) D. H. Stedman and H. Niki, "Kinetics and Mechanism for the Photolysis of $\mathrm{NO}_{2}$ in Air", typescript (1972).

(i) R. E. Huie, J. T. Herron, and D. D. Davis, J. Phys. Chem. 76, 2653 (1972).

(j) F. Kaufman and J.R. Kelso, J. Chem. Phys. 46, 4541 (1967).

(k) A. A. Westenberg and N. de Haas, J. Chem. Phys. 50, 707 (1969).

(1) F. S. Klein and J. T. Herron, J. Chem. Phys. 41, 1285 (1964).

(m) I. W. M. Smith, Trans. Faraday Soc. 64, 378 (1968).

(n) R. E. Huie, J. T. Herron, and D. D. Davis, J. Phys. Chem. $\underline{76}$, 3311 (1972).

(o) H. W. Ford and N. Endow, J. Chem. Phys. 27, 1156 (1957).

(p) E. A. Schuck, E. R. Stephens, and R. R. Schrock, J. Air Pol1. Cont. Assoc. 16, 695 (1966).

(q) S.W. Mayer, J. Phys. Chem. 71, 4159 (1967).

R. E. Huie, J. T. Herron

January, 1973 


\section{Chemica1 Kinetics Data Survey}

The Termolecular Association of $\mathrm{NO}_{2}$ and $\mathrm{O}\left({ }^{3} \mathrm{P}\right)$

1. $\mathrm{NO}_{2}+\mathrm{O}\left({ }^{3} \mathrm{P}\right)+\mathrm{M} \rightarrow \mathrm{NO}_{3}+\mathrm{M}$

2. $\Delta \mathrm{H}_{298}^{\circ}=-205 \pm 20 \mathrm{~kJ} \mathrm{~mol}{ }^{-1}\left(-49 \pm 5 \mathrm{kcal} \mathrm{mol}^{-1}\right)$

3. Data

a. Measurements of the rate of Reaction (1) in competition with the bimolecular reaction between $\mathrm{NO}_{2}$ and 0 :

$$
\mathrm{NO}_{2}+\mathrm{O} \rightarrow \mathrm{NO}+\mathrm{O}_{2}
$$

in the steady $u_{\bullet} v$. photolysis of $\mathrm{NO}_{2}$ at room temperature.

$$
\begin{aligned}
& \left(\mathrm{k}_{1} / \mathrm{k}_{2}\right) \times 10^{20} \\
& \left(\mathrm{~cm}^{3} / \text { molecule }\right) \\
& \hline
\end{aligned}
$$

7.7

$\mathrm{N}_{2}$

$\underline{\mathrm{M}}$

System

Stirred-flow photolysis reactor.

$\left[\mathrm{NO}_{2}\right]=8-130 \times 10^{12} \mathrm{molecule} / \mathrm{cm}^{3}$;

tota 1 pressure $=1$ atm; $\lambda=366 \mathrm{~nm}$.

Value of $k_{1} / k_{2}$ obtained from intercept

of plot of $1 / \Phi\left(\mathrm{NO}_{2}\right)$ vs. [NO]/[ $\left.\mathrm{NO}_{2}\right]$.

FORD, ENDOW 1957 (b)

1.12

$\mathrm{N}_{2}$

1.09

$\mathrm{CO}_{2}$
Static photolysis system.

Effect of total pressure (up to 1.5

atm) on $\Phi\left(\mathrm{NO}_{2}\right)$ studied. $\left[\mathrm{NO}_{2}\right]=$

$2 \times 10^{17}$ molecule $/ \mathrm{cm}^{3} ; \lambda=366 \mathrm{~nm}$. 


$$
\mathrm{NO}_{2}+\mathrm{O}+\mathrm{M} 2
$$

Values of $k_{1} / k_{2}$ are equal to slopes of $1 / \Phi\left(\mathrm{NO}_{2}\right)$ vs. [M] plots although not identified as such in paper. FORD. JAFFE 1963 (c)

1.34 $\mathrm{N}_{2} \quad$ Effect of addition of 1 atm $\mathrm{N}_{2}$ on ( $\left(\mathrm{NO}_{2}\right)$ measured. Black light fluorescent tube used; peak output at $350 \mathrm{~nm} . \quad\left[\mathrm{NO}_{2}\right]=4 \times 10^{14}$ molecule $/ \mathrm{cm}^{3}$. SHUCK, STEPHENS, SCHROCK 1966 (d)

1.10 $\mathrm{N}_{2} \quad$ Effect of $\mathrm{P}\left(\mathrm{N}_{2}\right)$ on $\cong\left(\mathrm{NO}_{2}\right)$ measured. $\left.\mathrm{NO}_{2}\right]^{?}=2 \times 10^{17}$ molecule $/ \mathrm{cm}^{3} ;:=366 \mathrm{~nm}$. Pressure range: 0.3 to $200 \mathrm{~atm}$. $\mathrm{k}_{1}$ found to be 3 rd order up to $10 \mathrm{~atm}$ and reached limiting 2 nd order value at $\sim 100 \mathrm{~atm}$.

TROE, 1969 (e)

1.36

$\mathrm{CO}_{2}$

16.6<smiles>[14CH3][TeH2]</smiles>

Effect of total pressure up to 2.2 atm on $\cong\left(\mathrm{O}_{2}\right)$ from photolysis of $\mathrm{NO}_{2}$ at

$313 \mathrm{~nm}$ measured. $\mathrm{NO}_{2}$ ? $=2 \times 10^{17}$

molecule/ $\mathrm{cm}^{3}$. Data for $\mathrm{C}_{2} \mathrm{H}_{4}, \mathrm{C}_{3} \mathrm{H}_{8}$, and $\mathrm{i}-\mathrm{C}_{4} \mathrm{H}_{10}$ as third bodies not quoted here; values are suspect because of reactivity with atomic oxygen.

BLACET. HALL, LEIGHTON 1962 (f) 
Photolysis of $\mathrm{NO}_{2}$ in 1 atm. air with black-light fluorescent lamps. $\left[\mathrm{NO}_{2}\right]$ $\sim 3 \times 10^{13}$ molecule $/ \mathrm{cm}^{3}$. NO produced monitored by its chemiluminescent reaction with $0_{3}$. Value of $k_{1} / k_{2}$ calculated from expression: $-d \ln \left[\mathrm{NO}_{2}\right] / \mathrm{dt}=2 \mathrm{I}_{\mathrm{a}} /$ $\left[1+k_{1}[M] / k_{2}\right]$ Absorbed light intensity, $I_{a}$, determined separately from initial rate of photolysis of $\mathrm{NO}_{2}$ in $\mathrm{O}_{2}$. STEDMAN, NIKI 1972 (g)

Photolysis of $\mathrm{NO}_{2}\left(10^{15}\right.$ molecules $\left./ \mathrm{cm}^{3}\right)$ in $\mathrm{N}_{2}$ (1 atm) with black light in 67 liter quartz tube. $\left[\mathrm{NO}_{2}\right]$ and $\left[\mathrm{N}_{2} \mathrm{O}_{5}\right]$ measured by i.r. absorption. Value of $\mathrm{k}_{1} / \mathrm{k}_{2}$ derived from $\mathrm{d}\left[\mathrm{NO}_{2}\right] / \mathrm{dt}$; values agreeing within $10 \%$ derived separately from $d\left[\mathrm{~N}_{2} \mathrm{O}_{5}\right] / d t$.

HARKER, JOHNSTON 1973 (h) 
b. Flash photolysis studies of reaction (1):

$\left(\mathrm{k}_{1}[\mathrm{M}]+\mathrm{k}_{2}\right) / \mathrm{k}_{3}$

1.8

4.2

$(\mathrm{T}=298 \mathrm{~K})$

$\left(k_{3}: 0+\mathrm{CS}_{2} \rightarrow \mathrm{CS}+\mathrm{s} 0\right)$
$\underline{P(M) / \text { torr }}$

100

700

$\underline{P(M)}$

$\mathrm{k}_{1}[\mathrm{M}]+\mathrm{k}_{2}$

$\left(\mathrm{cm}^{3}\right.$ molecule $\mathrm{s}^{-1}$ ) (torr)

$10.6 \times 10^{-12}$

200

$11.7 \times 10^{-12}$

400

$k_{2}=9.1 \times 10^{-12}$

$(\mathrm{T}=298 \mathrm{~K})$

\section{System}

0 atoms from flash photolysis of $\mathrm{NO}_{2}(\lambda>300 \mathrm{~nm}) \cdot \mathrm{M}=\mathrm{Ar} \cdot\left[\mathrm{NO}_{2}\right]$

$\sim 10^{15}-10^{16}$ molecule $/ \mathrm{cm}^{3}$. Total

reaction of 0 atoms with $\mathrm{NO}_{2}$ by

both channels ( (1) + (2) ) competes

with reaction with $\mathrm{CS}_{2}(3) \cdot \quad$ [CS ]

monitored by absorption at $257.6 \mathrm{~nm}$.

Data also given for $\mathrm{T}=410 \mathrm{~K}$.

SMITH 1968 (i)

0 atoms from flash photolysis of $\mathrm{O}_{2}$.

Resonance fluorescence used to monitor

atom decay by overal1 reaction with $\mathrm{NO}_{2}$

in both channels $((1)+(2))$.

$M=\operatorname{Ar} .\left[\mathrm{NO}_{2}\right] \sim 10^{14}$ molecule $/ \mathrm{cm}^{3}$.

Data also given for $\mathrm{T}=263 \mathrm{~K}$ and $230 \mathrm{~K}$.

HUIE 1972 (j) 


\section{Preferred Value}

$\frac{\mathrm{k}_{1}}{\mathrm{k}_{2}}\left(\mathrm{M}=\mathrm{N}_{2}\right)=1.1 \pm 0.4 \times 10^{-20} \mathrm{~cm}^{3} /$ molecule at $298 \mathrm{~K}$ $\mathrm{k}_{1}=1.0 \pm 0.5 \times 10^{-31} \mathrm{~cm}^{6}$ molecule $\mathrm{e}^{-2} \mathrm{~s}^{-1}$

based on $k_{2}=9.1 \times 10^{-12} \mathrm{~cm}^{3}$ molecule $\mathrm{e}^{-1} \mathrm{~s}^{-1}$ (value recommended in separate data sheet on $\mathrm{O}+\mathrm{NO}_{2} \rightarrow \mathrm{NO}+\mathrm{O}_{2}$ ).

\section{Remarks}

In the experiments involving the ultraviolet photolysis of nitrogen dioxide, the relative rate constant for reaction (1) was derived from the experimental quantum yields using the mechanism for the photolysis of $\mathrm{NO}_{2}$ :

$$
\begin{aligned}
& \mathrm{NO}_{2}+\mathrm{h} \nu \rightarrow \mathrm{NO}+\mathrm{O}\left({ }^{3} \mathrm{P}\right) \\
& 0+\mathrm{NO}_{2} \rightarrow \mathrm{NO}+\mathrm{O}_{2} \\
& 0+\mathrm{NO}_{2}+\mathrm{M} \rightarrow \mathrm{NO}_{3}+\mathrm{M} \\
& \mathrm{O}+\mathrm{NO}+\mathrm{M} \rightarrow \mathrm{NO}_{2}+\mathrm{M} \\
& \mathrm{NO}_{3}+\mathrm{NO} \rightarrow 2 \mathrm{NO}_{2} \\
& \mathrm{O}+\mathrm{O} 2+\mathrm{M} \rightarrow \mathrm{O}_{3}+\mathrm{M} \\
& \mathrm{O}_{3}+\mathrm{NO}_{2} \rightarrow \mathrm{NO}_{2}+\mathrm{O}_{2} \\
& \mathrm{NO}_{3}+\mathrm{NO}_{2} \rightarrow \mathrm{N}_{2} \mathrm{O}_{5}
\end{aligned}
$$

and assuming steady state values for $0, \mathrm{NO}_{3}$, and $\mathrm{O}_{3}$. Depending on the species being monitored and on the experimental conditions, various expressions leading to the ratio $k_{1} / k_{2}$ may be derived. 


$$
\mathrm{NO}_{2}+\mathrm{O}+\mathrm{M}
$$

The recommended value for $k_{1} / k_{2}$ is the simple average of the values (for $M=N_{2}$ ) from references $c, d$, e, $g$, and $h$. These values al1 lie within about $20 \%$ (one standard deviation) of the average value. The only value which deviates significantly is from reference (b). The data from which this value was obtained, however, show considerable scatter, and the derived value of the ratio is quite sensitive to small changes in the intercept of the plot, so that this value is rejected.

\section{Comments on measurements}

Ref (i). In this work, consistent results were unobtainable without the addition of $\mathrm{NO}$, presumably to remove $\mathrm{NO}_{3}$. The derived value of $k_{1} / k_{2}$ at $298 \mathrm{k}$ given there is a factor of eight higher than that recommended here. It is possible to derive the relationship: $\mathrm{k}_{1} / \mathrm{k}_{3}=1.2 \times 10^{-19} \mathrm{~cm}^{3} /$ molecule from the data at $[\mathrm{M}]=100$ and 700 torr. With the absolute value of $k_{3}$ measured in the same study $\left(k_{3}=4.0 \times 10^{-12} \mathrm{~cm}^{3}\right.$ molecule $\left.\mathrm{e}^{-1} \mathrm{~s}^{-1}\right)$, one can derive a value of $\mathrm{k}_{1}=5 \times 10^{-31} \mathrm{~cm}^{6}$ molecule $\mathrm{e}^{-2} \mathrm{~s}^{-1}$, almost a factor of five higher than the value of $k_{1}$ recommended here. In view of the complications in this system, these results are rejected. 


$$
\mathrm{NO}_{2}+\mathrm{O}+\mathrm{M} \quad 7
$$

Ref (j). The only direct measurement of $k_{1}$ reported is from reference (j). Although there were no apparent complications in the system, the procedure involved measuring a small (20-30\%) change, due to the contribution of reaction (1) in a large second order rate constant. At room temperature, the reported value of $k_{1}$ was about a factor of two higher than that recommended here. The temperature dependence of the reaction derived from these data is about $\mathrm{T}^{-5}$, which is far steeper than would be expected $\left(\sim T^{-3 / 2}\right)$ based on RRKM calculations on other atom-molecule addition reactions (k). These calculations also indicate that the observed pressure effect reported in $(j)$ at $230 \mathrm{~K}$ is too sharp.

\section{References}

(a) D. D. Wagman, W. H. Evans, V. B. Parker, I. Halow, S. M. Bailey, and R. H. Schumn, N. B. S. Tech. Note 270-3. Data on $\mathrm{NO}_{3}$ from JANAF Thermochemical Tables (1965).

(b) H. W. Ford and N. Endow, J. Chem. Phys. 27, 1156 (1957).

(c) H. W. Ford and S. Jaffe, J. Chem. Phys. 38, 2935 (1963).

(d) E. A. Schuck, E. R. Stephens, and R. R. Schrock, J. Air Pollution Control Assoc. 16,695 (1966).

(e) J. Troe, Ber. Bun. Phys. Chem. 73, 906 (1969).

(f) F. E. Blacet, T. C. Ha 11, and P. A. Leighton, J. Amer. Chem. Soc. 84,4011 (1962). 
(g) D. H. Stedman and H. Niki, "Kinetics and Mechanism for the Photolysis of $\mathrm{NO}_{2}$ in Air", typescript (1972).

(h) A. Harker and H. S. Johnston, J. Phys. Chem。 77, 1153 (1973).

(i) I. W. M. Smith, Trans. Faraday Soc. 64, 378 (1968).

(j) R. E. Huie, Ph.D. Thesis, University of Maryland (1972).

(k) W. I'sang, Private Communication (1973).

R. E. Huie

J. T. Herron

March, 1973 


$$
\mathrm{N}_{2} \mathrm{O}_{5}+\mathrm{h} \nu
$$

$$
\mathrm{N}_{2} \mathrm{O}_{5} \text { PHOTOCHEMTSTRY }
$$

\section{Reaction}

$\mathrm{N}_{2} \mathrm{O}_{5} \rightarrow \mathrm{N}_{2} \mathrm{O}_{4}+0\left({ }^{3} \mathrm{P}\right)$

$\mathrm{N}_{2} \mathrm{O}_{5} \rightarrow \mathrm{N}_{2} \mathrm{O}_{4}+\mathrm{O}\left({ }^{1} \mathrm{D}\right)$

$\mathrm{N}_{2} \mathrm{O}_{5} \rightarrow \mathrm{N}_{2} \mathrm{O}_{3}+\mathrm{O}_{2}$

$\mathrm{N}_{2} \mathrm{O}_{5} \rightarrow \mathrm{NO}_{3}+\mathrm{NO}_{2}$

\section{(Kcal/mol)}

57.8

103.2

15.9

21.4

\section{$\lambda$ threshold (nm)}

495

276

66

90

$\Delta \mathrm{H}_{\mathrm{O}}^{\circ} \quad$ calculated using $\Delta \mathrm{H}_{\mathrm{f}}^{\circ}$ values in ref [a] (except for $\Delta \mathrm{H}_{\mathrm{f}}^{\circ}\left(\mathrm{NO}_{3}\right.$ ) which is from JANAF tables but consistent with ref [a]) and excitation energy of $O\left({ }^{1} D\right)$ from ref $[\mathrm{b}]$

2. Data:

2a. Absorption spectrum

Wavelength Range

ultraviolet

450-250 nm

\section{Observation}

continuous absorption beginning at about $305 \mathrm{~nm}$ extending into the Schumann region UREY, DAWSEY, RICE, 1929 [c]

continuous absorption 450-320nm transparent $320-280 \mathrm{~nm}$. continuous absorption $\lambda<280 \mathrm{~nm}$. NOTE: $\mathrm{NO}_{2}$ always present DUTTA, SEN GUPTA, 1933 [d] 
$2 \mathrm{~b}$. Absorption Coefficient

Wavelength Range

$265-436 \mathrm{~mm}$

(selected $\mathrm{H}_{\mathrm{g}}$ lines)

285-380 nm. $\underline{\text { Data }}$

$\underline{\lambda(\mathrm{nm})} \quad \underline{\mathrm{k}}$

$265 \quad 2.1$

280

0.96

$302,313,334 \quad$ ZERO

$366,405,436$ ZERO

HOLMES, DANIELS, 1934 [e]

Value of $k$ rises

steadily from

$k=0.002$ at 380

$\mathrm{nm}$ to $\mathrm{k}=0.52$ at

$285 \mathrm{~nm}$.

See FIG. 1

JONES, WULF, 193- [f]
Unit

$1 \mathrm{~cm}^{-1}(\text { atm at } 273 \mathrm{~K})^{-1}$

base 10

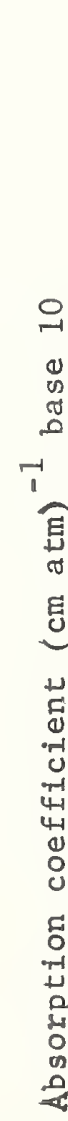

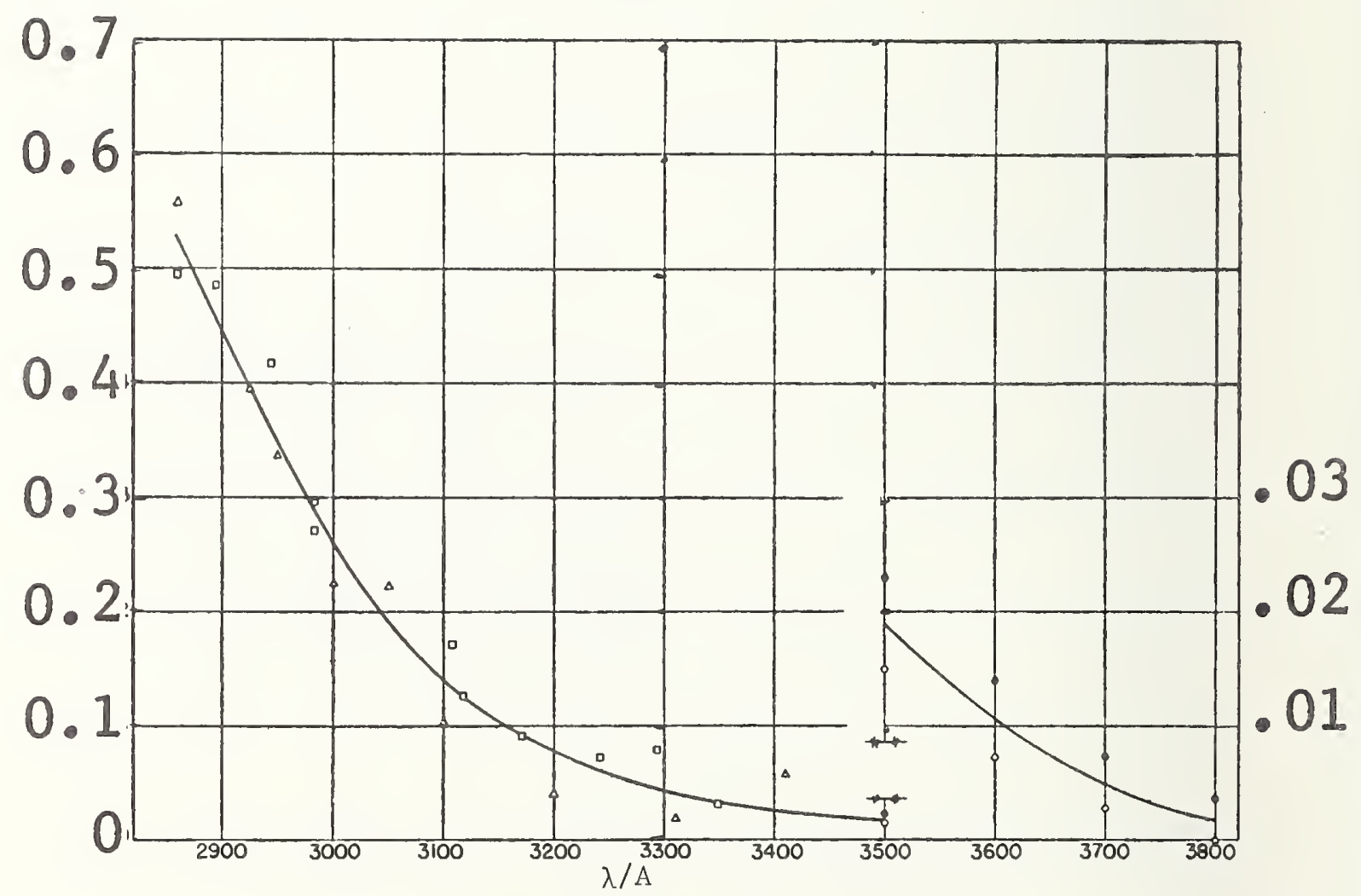

Fig. 1. Absorption coefficient of $\mathrm{N}_{2} \mathrm{O}_{5}$,

285-380 nm in units of $\mathrm{cm}^{-1}$ (atm at $\left.273 \mathrm{~K}\right)^{-1}$

base 10 (From E. J. Jones and 0 . R. Wulf,

J. Chem. Phys. 5, 873 (1937), reprinted with

consent of authors)

$1 \mathrm{~cm}^{-1}(\text { atm at } 273 \mathrm{~K})^{-1}$ base 10 
2c. Quantum yields

$\Phi\left(-\mathrm{N}_{2} \mathrm{O}_{5}\right)=$ net quantum yield for disappearance of $\mathrm{N}_{2} \mathrm{O}_{5}$

$\begin{array}{lcc}\frac{\lambda(\mathrm{nm})}{280} & \frac{\Phi\left(-\mathrm{N}_{2} \mathrm{O}_{5}\right)}{0.6} & \frac{\mathrm{P}_{\mathrm{N}_{2} \mathrm{O}_{5}}}{21 \text { torr, } 0{ }^{\circ} \mathrm{C}} \\ 280 & 0.6 & \text { eq. v.p. } 10^{\circ} \mathrm{C} \\ 265 & 0.6 & 51 \text { torr, } 0{ }^{\circ} \mathrm{C}\end{array}$

HOLMES, DANTELS, 1934 [e]

280

0.62

$14-51$ torr, $0.2^{\circ} \mathrm{C}$.

MURPHY, $1969[\mathrm{~g}]$

Effect of added inert gas on value of $\Phi\left(-\mathrm{N}_{2} \mathrm{O}_{5}\right)$

$\begin{array}{lllll}\underline{\mathrm{M}} & \frac{\mathrm{P}_{\mathrm{M}} \text { (torr) }}{\mathrm{SF}_{6}} & \frac{\Phi\left(-\mathrm{N}_{2} \mathrm{O}_{5}\right)}{210-620} & \frac{\mathrm{P}_{\mathrm{N}_{2} \mathrm{O}_{5}} \text { (torr) }}{25-30} & \\ \mathrm{CO}_{2} & 110-600 & 0.59-0.36 & 35-40 \quad \lambda=280 \mathrm{~nm} \\ \mathrm{~N}_{2} & 100-600 & 0.62-0.55 & 18-25 \quad \mathrm{t}=0.2{ }^{\circ} \mathrm{C} \\ \mathrm{O}_{2} & 100-600 & 0.53-0.29 & \approx 30 & \end{array}$

Because $\Phi\left(-\mathrm{N}_{2} \mathrm{O}_{5}\right)<1$ and decreases with increasing pressure of inert gas the photoabsorption act is believed to form an excited molecular state that can either dissociate or be quenched upon collision. The initial photodissociation products are unknown. The relationship between the overal1 $\Phi$ and the effective $\phi$ for photodissociation depends upon the extent of reaction of products of photolysis with $\mathrm{N}_{2} \mathrm{O}_{5}$. See section 4 for one mechanism. 


\section{Recommended values.}

3a. Absorption coefficients.

380-285 nm. Values shown in Fig. 1 (from [f])

280 and $265 \mathrm{~nm}$. Values in section $2 \mathrm{~b}$ (derived from [e])

To convert values given in $2 \mathrm{~b}$ into cross sections in $\mathrm{cm}^{2}$ molecule

(base e) multiply by $8.57 \times 10^{-20}$

3b. Quantum yields

According to mechanism of $\mathrm{N}_{2} \mathrm{O}_{5}$ photolysis given in section 4, the primary quantum yield for production of 0 atoms, $\phi_{0}=0.5 \mathrm{x}+\left(-\mathrm{N}_{2} 0_{5}\right)$

From the data of ref. $[\mathrm{g}]$ :

$\phi_{0}=\left(3.12+0.00084 \mathrm{P}_{\mathrm{N}_{L}}+0.0058 \mathrm{P}_{\mathrm{u}_{2}}\right)^{-1}$

where $\mathrm{P}_{\mathrm{N}_{2}}$ and $\mathrm{P}_{\mathrm{O}_{2}}$ are expressed in torr.

\section{Remarks}

The mechanism proposed for the photochemistry of pure $\mathrm{N}_{2} \mathrm{O}_{5}$ is:

$$
\begin{gathered}
\mathrm{N}_{2} \mathrm{O}_{5}\left(\mathrm{~S}_{\mathrm{O}}\right)+\mathrm{hv} \rightarrow \mathrm{N}_{2} \mathrm{O}_{5} *\left(\mathrm{~S}_{1}\right) \\
\mathrm{N}_{2} \mathrm{O}_{5} *\left(\mathrm{~S}_{1}\right) \rightarrow \mathrm{N}_{2} \mathrm{O}_{5} *\left(\mathrm{~T}_{1}\right) \\
\mathrm{N}_{2} \mathrm{O}_{5} *\left(\mathrm{~T}_{1}\right) \rightarrow \mathrm{N}_{2} \mathrm{O}_{4}+0 \\
\mathrm{~N}_{2} \mathrm{O}_{5} *\left(\mathrm{~T}_{1}\right)+\mathrm{M} \rightarrow \mathrm{N}_{2} \mathrm{O}_{5}+\mathrm{M} \\
0+\mathrm{N}_{2} \mathrm{O}_{5} \rightarrow \mathrm{N}_{2} \mathrm{O}_{4}+\mathrm{O}_{2}\left(\text { or } 2 \mathrm{NO}_{2}+\mathrm{O}_{2}\right) .
\end{gathered}
$$

By this mechanism, the limiting low pressure primary quantum yield for the production of 0 atoms is one-half the value of $\Phi\left(-\mathrm{N}_{2} \mathrm{O}_{5}\right)$ obtained in the absence of inert gas, i.e. $0.5 \times 0.62=0.31$. 


\section{References}

[a] D. D. Wagman et al, NBS Technical Note 270-3 (Jan. 1968).

[b] C. E. Moore, NBS Circular 467, vol. 1 (1949).

[c] H. C. Urey, L. H. Dawsey, and F. O. Rice J.Am. Chem. Soc. 51, 3190 (1929).

[d] A. K. Dutta and P. K. Sen Gupta Proc. Roy. Soc. (London) A139, 397 (1933).

[e] H. Holmes and F. Daniels J. Am. Chem. Soc. 56, 630 (1934).

[f] E. J. Jones and O. R. Wulf J. Chem. Phys. $\underline{5}, 873$ (1937).

[g] R. F. Murphy, "The Ultraviolet Photolysis of the Nitrogen Oxides," Dissertation, U. C. L. A. (1969).

R. Hampson

Nov. 1972 


$$
\text { Photolysis of } \mathrm{O}_{2}
$$

1. Primary Photochemical Transitions

\begin{tabular}{|c|c|c|c|}
\hline & $\Delta \mathrm{H}_{0}^{\mathrm{O}}$ & & \\
\hline Reaction & $\mathrm{kJ} / \mathrm{mo} 1$ & $(\mathrm{kcal} / \mathrm{mol})$ & $\lambda$ threshold (nm) \\
\hline $\mathrm{O}_{2} \rightarrow \mathrm{o}\left({ }^{3} \mathrm{p}\right)+\mathrm{o}\left({ }^{3} \mathrm{p}\right)$ & 493.57 & $(117.97)$ & 242.4 \\
\hline$\rightarrow O\left({ }^{3} \mathrm{P}\right)+O\left({ }^{1} \mathrm{D}\right)$ & 683.39 & $(163.33)$ & 175.0 \\
\hline$\rightarrow O\left(^{3} \mathrm{p}\right)+o\left({ }^{1} \mathrm{~s}\right)$ & 897.81 & $(214.58)$ & 133.2 \\
\hline
\end{tabular}

$\left(\triangle \mathrm{H}_{0}^{O}\right.$ values calculated from $\Delta \mathrm{H}_{f}^{O}(0)$ in (a) and energies of excitation of $O\left({ }^{1} D\right)$ and $O\left({ }^{1} S\right)$ in $\left.(b)\right)$.

2. Absorption Coefficient Data

Wavelength range

$<300 \mathrm{~nm}$

175-205 nm
Sys tem

Critical review of $u \cdot v$. absorption cross section data. HUDSON, 1971 (c)

Computed absorption cross section at high resolution of the SchumannRunge bands from $(0,0)$ band at $205 \mathrm{~nm}$ to dissociation limit at $175 \mathrm{~nm}$. ACKERMAN, BIAUME, KOCKARTS, 1970 (d) 
$178-205 \mathrm{~nm}$

$116-244 \mathrm{~nm}$

$181-235 \mathrm{~nm}$

$243-264 \mathrm{~nm}$

$192-243 \mathrm{~nm}$
High-resolution study of

structure of Schumann-Runge

bands from $(0,0)$ to $(13,0)$ band.

ACKERMAN, BIAUME, 1970 (e)

Table of adopted values of

absorption cross section averaged

over $500 \mathrm{~cm}^{-1}$ intervals.

ACKERMAN，1971 (f)

Absorption cross section of the

$\mathrm{O}_{2}$ continuum and its pressure

dependence measured.

OGAWA, 1971 (g)

Absorption measured for eight

bands of the Herzberg I

$\left(\mathrm{A}^{3} \Sigma_{\mathrm{u}}^{+}-\mathrm{X}^{3} \mathrm{\Sigma}_{\mathrm{g}}^{-}\right)$system.

HASSON, NICHOLLS, 1971 (h1)

Absorption cross section of weak

photodissociation continuum

adjoining the Herzberg I system

measured over $109 \mathrm{ft}$. path length.

HASSON, NICHOLLS 1971 (h2). 


$$
\mathrm{o}_{2}+\mathrm{h}_{\nu}
$$

$$
175-203 \mathrm{~nm}
$$

Band oscillator strengths and predissociation line widths of Schumann-Runge band system derived. Continuum cross section calculated from $176-210 \mathrm{~nm}$ for $\mathrm{T}=150,200,250$, and $300 \mathrm{~K}$. HUDSON, MAHLE 1972 (i)

\section{Photochemical Data}

A recent review and compilation of spectroscopic data (including the u.v. spectrum) of $\mathrm{O}_{2}$ is given in ref $(j)$.

a) $\underline{\lambda>175 \mathrm{~nm}}$

$$
\begin{aligned}
& \text { a1. Spectroscopy }(c, k, l, m) \\
& \lambda \text { range Transition Name } \\
& \text { 185-260 nm } \quad \mathrm{A}^{3} \Sigma_{\mathrm{u}}^{+} \rightarrow \mathrm{x}^{3} \Sigma_{\mathrm{g}}^{-} \quad \text { Herzberg } \\
& \text { Continuum } \\
& \text { 175-200 nm } \quad \mathrm{B}^{3} \Sigma_{\mathrm{u}}^{-} \rightarrow \mathrm{x}^{3} \Sigma_{\mathrm{g}}^{-} \quad \text { Schumann-Runge } \\
& \text { Band System }
\end{aligned}
$$

The $B^{3} \Sigma_{u}^{-}$predissociates by crossing at about the $v^{\prime}=2$ level to the ${ }^{3} \Pi_{u}$ state. 
a2. Photochemistry

At $\lambda=184.9 \mathrm{~nm} \emptyset(0)=2$ based on $\Phi\left(0_{3}\right)=2.0$ for $\mathrm{P}\left(0_{2}\right)>100$ torr (ref $n)\left(\Phi\left(\mathrm{O}_{3}\right)\right.$ measured relative to $\Phi\left(\mathrm{N}_{2}\right)$ from $\mathrm{N}_{2} 0$ which was taken to be 1.44$)$. At $P\left(0_{2}\right)<100$ torr $\Phi\left(0_{3}\right)$ decreases presumably due to 0 atom wall losses. Such a decrease is apparently an experimental artifact and not indicative of primary photochemical processes. The same study at $193.1 \mathrm{~nm}$ reports $\Phi\left(\mathrm{O}_{3}\right)=0.3$ independent of $\mathrm{P}\left(\mathrm{O}_{2}\right)$ from 300 to 1300 torr. The explanation requires direct excitation and subsequent quenching of a rotational line of the S-R continuum. This is contrary to spectroscopic evidence (c) which indicates that all of the rotational lines near $193 \mathrm{~nm}$ are strongly predissociated.

\section{b) $175>\lambda>133.2 \mathrm{~nm}$}

\section{b1. Spectroscopy (c)}

Absorption consists of the Schumann-Runge $(B \rightarrow X)$ dissociation continuum $\left(O\left(^{3} P\right)+O\left({ }^{1} D\right)\right)$ with two superimposed continua bands centered at 135.2 and $133.2 \mathrm{~nm}$. The former has been suggested to correspond to the spin-forbidden dissociation of $0_{2}$ into two $0\left({ }^{1} D\right)$ atoms. The low wavelength boundary of this region corresponds to the thermochemical onset for the dissociation into $0\left(^{3} \mathrm{P}\right)+0\left({ }^{1} \mathrm{~S}\right)$. 


\section{b2. Photochemistry}

Emission from $O\left({ }^{1} D\right)$ at $630 \mathrm{~nm}\left(O\left(^{1} D\right) \rightarrow O\left({ }^{3} P\right)\right)$ has been observed by Noxon (o) in the $147 \mathrm{~nm}$ photolysis of $0_{2}$. Emission from $0_{2}\left(\mathrm{~b}^{1_{\Sigma}^{+}}{ }_{\mathrm{g}}\right)$ at $760 \mathrm{~nm}\left(\mathrm{~b}^{1_{\Sigma^{\prime}}^{+}} \rightarrow \mathrm{x}^{3} \Sigma_{\mathrm{g}}^{-}\right)$was also observed. The $0_{2}\left(b^{1} \Sigma_{g}^{+}\right)$is presumed to be produced in the reaction:

$$
O\left({ }^{1} \mathrm{D}\right)+0_{2}\left(\mathrm{X}^{3} \Sigma_{g}^{-}\right) \rightarrow O\left(^{3} \mathrm{P}\right)+\mathrm{O}_{2}\left(\mathrm{~b}^{\Sigma_{\Sigma}^{+}}{ }_{\mathrm{g}}^{+}\right)
$$

on the basis of the intensity of the $760 \mathrm{~nm}$ emission and assuming that $0_{2}\left(b^{1} \Sigma_{g}^{+}\right)$is produced in the above reaction with $100 \%$ efficiency, an "order of magnitude" calculation indicated that $O\left({ }^{1} D\right)$ and $O\left(^{3} P\right)$ are formed in equal amounts in the primary photolysis of $0_{2}$ at $147 \mathrm{~nm}$. The $147 \mathrm{~nm}$ photolysis of $\mathrm{O}_{2}$ in the presence of $\mathrm{H}_{2}$ and $\mathrm{NO}$ was studied by Young $(p)$. Assuming that $O\left(^{1} D\right)$ reacts with but is not quenched to $O\left(^{3} \mathrm{P}\right)$ by $\mathrm{H}_{2}$, and that $O\left(^{3} \mathrm{P}\right)$ reacts with NO to form $\mathrm{NO}_{2}{ }^{*}$ which fluoresces, he found that the $O\left({ }^{1} D\right)$ and $O\left(^{3} \mathrm{P}\right)$ productions are equal. other investigators $(q, r)$ have monitored $\mathrm{O}_{3}$ formation to deduce thereby total 0 atom quantum yields of 2 but were unable to distinguish between $O\left({ }^{3} P\right)$ and $O\left({ }^{1} D\right)$. The fall-off in $\Phi\left(O_{3}\right)$ at low pressure was also observed in these systems and has been inadequately explained on the basis of $O\left({ }^{1} D\right)$ reactions. 
c) $133.2>\lambda>100 \mathrm{~nm}$

\section{c1. Spectros copy (c)}

A continuum in the Schumann-Runge system centered at $133.2 \mathrm{~nm}$ is presumedly due to the onset of the dissociation of $0_{2}$ into $O\left({ }^{3} \mathrm{P}\right)$ and $O\left(^{1} \mathrm{~S}\right)$. The region between $102.7 \mathrm{~nm}$, corresponding to the ionization potential of $\mathrm{O}_{2}$, and $130 \mathrm{~nm}$ consists of a large number of strong absorption bands. A narrow window at Lyman- $\alpha, 121.56 \mathrm{~nm}$ has been observed repeatedly.

\section{c2. Photochemistry}

Emission from $O\left({ }^{1} S\right)$ at $557.7 \mathrm{~nm}\left(O\left({ }^{1} S\right) \rightarrow O\left({ }^{1} D\right)\right)$ has been observed in the flash photolysis of $\mathrm{O}_{2}$ between 134 and $105 \mathrm{~nm}$ (s). This emission is enhanced in the presence of $\mathrm{Ar}, \mathrm{Kr}$, or $\mathrm{Xe}$. The quantum yield for production of $O\left({ }^{1} S\right)$ has not been determined.

\section{Preferred values}

a. Absorption Coefficients

243-195 nm

210-176 nm
Use data of HASSON and NICHOLLS (h2).

a) Continuum cross sections: use data Table 4 of HUDSON \& MAHLE (i).

b) Schumann-Runge bands: use data in ACKERMAN, BIAUME', AND KOCKARTS (d). 
175-135 nm

$244-116 \mathrm{~nm}$
See Figures 13, 14, and 15 of HUDSON (c).

The most conveniently tabulated

data is that given by ACKERMAN in

Table 1 of ref (f). These are

average adopted values not

significantly different from

values recommended above. They

are given here in Table 1.

b. Quantum yields

$$
\begin{aligned}
& \text { b1. } 0_{2}+h \nu \rightarrow O\left({ }^{3} P\right)+o\left({ }^{3} P\right) \\
& 200>\lambda>175 \mathrm{~nm} \quad \emptyset=1 \\
& \text { b2. } 0_{2}+h \nu \rightarrow O\left({ }^{3} P\right)+o\left({ }^{1}\right) \\
& 175>\lambda>133 \mathrm{~nm} \quad \emptyset=1 \\
& \text { b3. } \mathrm{O}_{2}+\mathrm{h} \nu \rightarrow 0+0 \\
& 200>\lambda>106 \mathrm{~nm} \quad \emptyset=1
\end{aligned}
$$

\section{Remarks}

No photolytic system studied to date has used wavelengths corresponding to thresholds indicated in section 1. Quantum yields for production of oxygen atoms in specific electronic states are needed. 
TABLE 1. Averaged absorption cross section values (from Ackerman, reference f)

\begin{tabular}{|c|c|c|}
\hline$\Delta:(\AA)$ & $\Delta v\left(\mathrm{~cm}^{-1}\right)$ & $\sigma\left(\mathrm{O}_{2}\right)\left(\mathrm{cm}^{2}\right)$ \\
\hline Lya $1.215,67$ & 82.259 & $1.00 \times 10^{-20}$ \\
\hline $1.170-1.163$ & $85.500-86.000$ & $2.00 \times 10^{-20}$ \\
\hline $1.1 .76-1.170$ & $85.000-85.500$ & $1.2 .5 \times 10^{-1.8}$ \\
\hline $1.183-1.176$ & $84.500-85.000$ & $2.55 \times 10^{-19}$ \\
\hline $1.190-1.183$ & $84.000-84.500$ & $3.00 \times 10^{-20}$ \\
\hline $1.198-1.190$ & $83.500-84.000$ & $3.75 \times 10^{-1.9}$ \\
\hline $1.205-1.298$ & $83.000-83.500$ & $4.4 .5 \times 10^{-1.8}$ \\
\hline $1.212-1.205$ & $82.500-83.000$ & 8.35 \\
\hline $1.220-1.212$ & $82.000-82.500$ & $6.00 \times 10^{-19}$ \\
\hline $1.227-1.220$ & $81.500-82.000$ & 2.35 \\
\hline $1.235-1.227$ & $81.000-81.500$ & 4.50 \\
\hline $1.242-1.235$ & $80.500-81.000$ & 3.35 \\
\hline $1.250-1.242$ & $80.000-80.500$ & $1.75 \times 10^{-17}$ \\
\hline $1.258-1.250$ & $79.500-80.000$ & $8.95 \times 10^{-19}$ \\
\hline $1.266-1.258$ & $79.000-79.500$ & 4.30 \\
\hline $1.274-1.266$ & $78.500-79.000$ & 1.10 \\
\hline $1.282-1.274$ & $78.000-78.500$ & 2.05 \\
\hline $1.290-1.282$ & $77.500-78.000$ & 4.43 \\
\hline $1.299-1.290$ & $77.000-77.500$ & 5.55 \\
\hline $1.307-1.299$ & $76.500-77.000$ & 4.20 \\
\hline $1.316-1.307$ & $76.000-76.500$ & 6.85 \\
\hline $1.324-1.316$ & $75.500-76.000$ & $1.45 \times 10^{-18}$ \\
\hline $1.333-1.324$ & $75.000-75.500$ & $? .2 .5$ \\
\hline $1.342-1.333$ & $74.500-75.000$ & 2.30 \\
\hline $1.351-1.342$ & $74.000-74.500$ & 4.55 \\
\hline $1.360-1.351$ & $73.500-74.000$ & 7.23 \\
\hline $1.370-1.360$ & $73.000-73.500$ & 9.50 \\
\hline $1.379-1.370$ & $72.500-73.000$ & $1.23 \times 10^{-17}$ \\
\hline $1.389-1.379$ & $72.000-72.500$ & 1.32 \\
\hline $1.408-1.389$ & $71.000-72.000$ & 1.36 \\
\hline $1.428-1.408$ & $70.000-71.000$ & 1.40 \\
\hline $1.449-1.428$ & $69.000-70.000$ & 1.48 \\
\hline
\end{tabular}


TABLE 1 (Continued)

\begin{tabular}{|c|c|c|}
\hline$\Delta \lambda(\Lambda)$ & $\Delta v\left(\mathrm{~cm}^{-1}\right)$ & $o\left(\mathrm{O}_{2}\right)\left(\mathrm{cm}^{2}\right)$ \\
\hline $1.470-1.449$ & $68.000-69.000$ & $1.41 \times 10^{-17}$ \\
\hline $1.1392-1.470$ & $67.000-68.00 n$ & 1.29 \\
\hline $1.51 .5-1.1392$ & $66.000-57.000$ & 1.15 \\
\hline $1.538-1.51 .5$ & $65.000-66.000$ & $9.91 \times 10^{-18}$ \\
\hline $1.502-1.538$ & $64.000-65.000$ & 8.24 \\
\hline $1.5837-1.562$ & $63.000-64.000$ & 6.58 \\
\hline $1.6 ! 3-1.5837$ & $62.000-63.000$ & 4.97 \\
\hline$? .639-1.613$ & $61.000-62.000$ & 3.45 \\
\hline $1.647-1.639$ & $60.000-61.000$ & 2.08 \\
\hline $1.095-1.667$ & $59.000-60.000$ & 1.2 .3 \\
\hline $1.724-1.695$ & $5.8 .000-59.0 n n$ & $7.2 .2 .2510^{-19}$ \\
\hline $1.739-1.724$ & $57.500-5.000$ & 4.58 \\
\hline$i .75 / 4 .-1.739$ & $" 7.0 n n-57$ siric & 2.74 \\
\hline 8 ongat $-3,7.74$ & $.49 .907 ;-57.0 \mathrm{nn}$ & $n$ \\
\hline $2.011-2.020$ & $49.000-49.500$ & $1.14 \times 10^{-2.3}$ \\
\hline $2.062-2.041$ & $48.500-49.000$ & 1.05 \\
\hline $2.083-2.062$ & $48.000-43.500$ & 1.00 \\
\hline $2.105-2.083$ & $47.500-40.000$ & $9.5,5 \times 10^{-2.4}$ \\
\hline $2.120-2.105$ & $47.000-47.500$ & 8.93 \\
\hline $2.150-2.128$ & $46.500-47.000$ & 8.2 .8 \\
\hline $2.174-2.1 .50$ & $46.000-46.500$ & 7.60 \\
\hline $2.198-2.174$ & $45.500-46.000$ & $6.9 ?$ \\
\hline $2.222-2.198$ & $45.000-45.500$ & 6.2 .8 \\
\hline $2.247-2.222$ & $44.500-45.000$ & $5.6 r$ \\
\hline $2.273-2.247$ & $44.000-4 / 3.50()$ & $5.0 \%$ \\
\hline $2.299-2.273$ & $43.500-14.000$ & 4.40 \\
\hline $2.326-2.299$ & $43.000-43.500$ & 3.76 \\
\hline $2.353-2.326$ & $42.500-43.000$ & 3.09 \\
\hline $2.381-2.393$ & $42.000-42.500$ & $2.4 / 4$ \\
\hline $2.1310-2.381$ & $41.500-42.000$ & 1.75 \\
\hline $2.439-2.410$ & $41.000-41.500$ & $6.74 \times 10^{-25}$ \\
\hline
\end{tabular}




\section{$\underline{\text { References }}$}

a. D. D. Wagman et a1, NBS Technical Note 270-3 (Jan. 1968).

b. C. E. Moore, NBS Circular 467, vol. 1 (1949).

c. R. D. Hudson, Rev. Geophys. Space Phys. 9, 305 (1971).

d. M. Ackerman, F. Biaume, and G. Kockarts, Planet. Space Sci. 18, 1639 (1970).

e. M. Ackerman and F. Biaume, J. Mo1. Spectrosc. 35, 73 (1970).

f. M. Ackerman, "Ultraviolet Solar Radiation Related to Mesospheric Processes," Aeronomica Acta No. 77 (1970). Available through National Technical Information Service, N71-13825. Also published in "Mesospheric Models and Related Experiments," G. Fiocco, ed., D. Reide1 PubI. Co. (1971).

g. M. Ogawa, J. Chem. Phys. 54, 2550 (1971).

h. V. Hasson and R. W. Nicholls, J. Phys. B: Atom. Molec. Phys. 4, 1778 (1971); ibid. 4, 1789 (1971).

i. R. D. Hudson and S. H. Mahle, J. Geophys. Res. 77, 2902 (1972).

j. P. Krupenie, J. Phys. Chem. Ref. Data 1, 423 (1972).

k. P. K. Carro11, Astrophys. J. 129, 794 (1959).

1. D. H. Volman, Advances in Photochemistry 1, 43 (1963).

m. J. G. Calvert and J. N. Pitts, Photochemistry, p. 205 (John Wiley \& Sons Inc. 1966).

n. N. Washida, Y. Mori, and I. Tanaka J. Chem. Phys. 54, 1119 (1971). o. J. F. Noxon, J. Chem. Phys. 52, 1852 (1970); ibid 57, 1033 (1972). 


$$
\mathrm{O}_{2}+\mathrm{h} \nu
$$

P. R. A. Young, G. Black, and T. G. Slanger, J. Chem. Phys. 49, 4758 (1968).

q. J. O. Sullivan and P. Warneck, J. Chem. Phys. 46, 953 (1967).

r. M. Clerc, A. Reiffsteck, and B. Lesigne, J. Chem. Phys. 50, 3721 (1969).

s. S. V. Filseth and K. H. Welge, J. Chem. Phys. 51, 839 (1969).

A. H. Laufer

May 1973 
Reactions of Potential Interest for the Chemistry of the Stratosphere

(Revised May 1973)

This list of reactions is based on several sources. It includes those used in models by P. J. Crutzen, J. Geophys. Res. 76, 7311 (1971), Univ. of Stockholm Meteorology Report AP-6 (1971); by H. S. Johnston, Science 173, 517 (1971), UCRL Report 20568 (1971), MS. "Formation and Stability of Nitric Oxide in the Stratosphere" (July 1971), and mentioned in discussions; those considered important by J. London and H. U. Dutsch, letter from J. L. to D. G., Oct. 19, 1971; and other reactions considered in studies at NBS.

The reactions are arranged in alphabetical order by first reactant. Notes on entries in the Table:

1. Importance in Stratosphere. An asterisk in this column indicates that a student of the atmospheric modelling problems considers this reaction to be important. Absence of a mark does not imply the opposite.

2. Status of Data. An asterisk in this column indicates that an evaluator or modeller considers that better measurements are needed. Other remarks indicate the reliability of the data as assessed by an evaluator. Absence of a mark or comment has no significance.

3. Evaluation. References to recent evaluations are given here. The listing may not be complete. The notations are identified below.

a. R. F. Hampson et al, "Survey of Photochemical and Rate Data for Twenty-Eight Reactions of Interest in Atmospheric Chemistry", to appear in J. Phys. Chem. Ref. Data $\underline{2}$, No. 2 (Summer 1973). (Updated versions of evaluations in NBS Reports 10692 and 10828). 
b. R. F. Hampson et al, NBSIR 73-207, May 1973, (this report).

c. D. Garvin, editor, NBSIR 73-203 (May 1973).

d. D. Garvin, editor, NBSIR 73-206 (May 1973).

e. D.L. Baulch, D. D. Drysdale, D. G. Horne, A. C. LIoyd,

"Evaluated Kinetic Data for High Temperature Reactions, Volume 1, Homogeneous gas phase reactions of the $\mathrm{H}_{2}-\mathrm{O}_{2}$ system", Butterworth and Co., London (1972).

f. H. S. Johnston, Nat. Stand. Ref. Data Ser. - NBS 20 (1968).

g. A. C. Lloyd, NBS Report 10447 (July 1971).

h. K. Schofield, J. Phys. Chem. Ref. Data 2, 25 (1973).

i. W. E. Wilson, Jr., J. Phys. Chem. Ref. Data 1, 535 (1972). 
$\mathrm{CH}_{4}+\mathrm{O}\left({ }^{1} \mathrm{D}\right) \rightarrow \mathrm{CH}_{3}+\mathrm{HO}$

*

$\mathrm{CO}+\mathrm{HO} \rightarrow \mathrm{CO}_{2}+\mathrm{H}$

$\mathrm{H}+\mathrm{HNO} \rightarrow \mathrm{H}_{2}+\mathrm{NO}$

$\mathrm{H}+\mathrm{HNO}_{2} \rightarrow$ Products

$\mathrm{H}+\mathrm{HNO}_{3} \rightarrow$ Products

$\mathrm{H}+\mathrm{H}_{2} \mathrm{O}_{2} \rightarrow \mathrm{H}_{2}+\mathrm{HO}_{2}$

$\mathrm{H}+\mathrm{NO}_{2} \rightarrow \mathrm{HO}+\mathrm{NO}$

$\mathrm{H}+\mathrm{O}_{2}+\mathrm{M} \rightarrow \mathrm{HO}_{2}+\mathrm{M}$

$\mathrm{H}+\mathrm{O}_{3} \rightarrow \mathrm{HO}+\mathrm{O}_{2}$

$\mathrm{HNO}+\mathrm{HO} \rightarrow \mathrm{H}_{2} \mathrm{O}+\mathrm{NO}$

$\mathrm{HNO}_{2}+\mathrm{HO} \rightarrow \mathrm{H}_{2} \mathrm{O}+\mathrm{NO}_{2}$

$\mathrm{HNO}_{2}+\mathrm{O} \rightarrow \mathrm{HO}+\mathrm{NO}_{2}$

$\mathrm{HNO}_{2}+\mathrm{h} v \rightarrow$ Products

$\mathrm{HNO}_{3}+\mathrm{HO} \rightarrow \mathrm{H}_{2} \mathrm{O}+\mathrm{NO}_{3}$

$\mathrm{HNO}_{3}+\mathrm{O} \rightarrow \mathrm{HO}+\mathrm{NO}_{3}$

$\mathrm{HNO}_{3}+\mathrm{h \nu} \rightarrow \mathrm{HO}+\mathrm{NO}_{2}$

$\mathrm{HO}+\mathrm{HO} \rightarrow \mathrm{H}_{2} \mathrm{O}+\mathrm{O}$

$\mathrm{HO}+\mathrm{HO}_{2} \rightarrow \mathrm{H}_{2} \mathrm{O}+\mathrm{O}_{2}$

$\mathrm{HO}+\mathrm{H}_{2} \mathrm{O}_{2} \rightarrow \mathrm{H}_{2} \mathrm{O}+\mathrm{HO}_{2}$

* $\pm 0.1$

d

$$
\pm 0.1
$$

c

upper limit only

$a, d$

no data

a

upper limit on $1 y$

a

$\pm 0.3$

e, d

$\pm 0.1$

a, d

$\pm 0.07$

c

$\pm 0.1$

a

$\pm 0.7(\mathrm{~T}>1600 \mathrm{~K})$

a, d

no data

a

no data

a

no data

b

$\pm 0.5$

a

upper limit only

a

$\sigma$ data only

a

$\pm 0.2$

e

$\pm 1$

$g, e, c$

$\pm 0.1$

b, e 


\begin{tabular}{|c|c|c|c|}
\hline $\mathrm{HO}+\mathrm{NO}+\mathrm{M} \rightarrow \mathrm{HNO}_{2}+\mathrm{M}$ & $*$ & \pm 0.5 & $\mathrm{~b}$ \\
\hline $\mathrm{HO}+\mathrm{NO}_{2}+\mathrm{M} \rightarrow \mathrm{HNO}_{3}+\mathrm{M}$ & $*$ & \pm 0.3 & $\mathrm{~b}$ \\
\hline $\mathrm{HO}+\mathrm{O} \rightarrow \mathrm{H}+\mathrm{O}_{2}$ & $*$ & \pm 0.3 & e, i \\
\hline $\mathrm{HO}+\mathrm{O}_{3} \rightarrow \mathrm{HO}_{2}+\mathrm{O}_{2}$ & $*$ & \pm 0.3 & a \\
\hline $\mathrm{HO}_{2}+\mathrm{HO}_{2} \rightarrow \mathrm{H}_{2} \mathrm{O}_{2}+\mathrm{O}_{2}$ & $*$ & \pm 0.3 & $\mathrm{a}, \mathrm{e}$ \\
\hline $\mathrm{HO}_{2}+\mathrm{NO} \rightarrow \mathrm{HO}+\mathrm{NO}_{2}$ & $*$ & \pm 0.5 & c \\
\hline $\mathrm{HO}_{2}+\mathrm{NO}+\mathrm{M} \rightarrow \mathrm{HNO}_{3}+\mathrm{M}$ & $*$ & & \\
\hline $\mathrm{HO}_{2}+\mathrm{O} \rightarrow \mathrm{HO}+\mathrm{O}_{2}$ & $*$ & \pm 1 & g \\
\hline $\mathrm{HO}_{2}+\mathrm{O}_{3} \rightarrow \mathrm{HO}+2 \mathrm{O}_{2}$ & * & \pm 0.3 & c \\
\hline $\mathrm{HO}_{2}+\mathrm{hv} \rightarrow \mathrm{HO}+\mathrm{O}$ & $*$ & $\begin{array}{l}\sigma \pm 30 \% \\
\text { some } \phi \text { data }\end{array}$ & $\mathrm{d}$ \\
\hline $\mathrm{H}_{2} \mathrm{O}+\mathrm{NO}+\mathrm{NO}_{2} \rightarrow 2 \mathrm{HNO}_{2}$ & & upper limit only & $\mathrm{a}$ \\
\hline $\mathrm{H}_{2} \mathrm{O}+\mathrm{N}_{2} \mathrm{O}_{5} \rightarrow 2 \mathrm{HNO}_{3}$ & $*$ & upper limit only & $\mathrm{a}$ \\
\hline $\mathrm{H}_{2} \mathrm{O}+\mathrm{O}\left({ }^{1} \mathrm{D}\right) \rightarrow 2 \mathrm{HO}$ & $*$ & \pm 0.1 & $\mathrm{~d}, \mathrm{a}$ \\
\hline $\mathrm{H}_{2} \mathrm{O}+\mathrm{h \nu} \rightarrow \mathrm{HO}+\mathrm{O}$ & $*$ & & \\
\hline $\mathrm{H}_{2} \mathrm{O}_{2}+\mathrm{NO} \rightarrow \mathrm{HO}+\mathrm{HNO}_{2}$ & & upper limit only & $\mathrm{a}$ \\
\hline $\mathrm{H}_{2} \mathrm{O}_{2}+\mathrm{hv} \rightarrow 2 \mathrm{HO}$ & $*$ & $\sigma, \phi$ & $\mathrm{a}$ \\
\hline $\mathrm{NO}+\mathrm{NO}+\mathrm{O}_{2} \rightarrow 2 \mathrm{NO}_{2}$ & $*$ & \pm 0.2 & c \\
\hline $\mathrm{NO}+\mathrm{NO}_{2} \rightarrow \mathrm{N}_{2} \mathrm{O}_{3}$ & & & \\
\hline $\mathrm{NO}+\mathrm{NO}_{3} \rightarrow 2 \mathrm{NO}_{2}$ & * & \pm 0.7 & $\mathrm{~d}$ \\
\hline
\end{tabular}


$\mathrm{NO}+\mathrm{O}+\mathrm{M} \rightarrow \mathrm{NO}_{2}+\mathrm{M}$

$\mathrm{NO}+\mathrm{O}_{3} \rightarrow \mathrm{NO}_{2}+\mathrm{O}_{2}$

$\mathrm{NO}+\mathrm{h \nu} \rightarrow \mathrm{N}+\mathrm{O}$

$\mathrm{NO}+\mathrm{M} \rightarrow \mathrm{N}+\mathrm{O}+\mathrm{M}$

$\mathrm{NO}_{2}+\mathrm{NO}_{2}+\mathrm{M} \rightarrow \mathrm{N}_{2} \mathrm{O}_{4}+\mathrm{M}$

$\mathrm{NO}_{2}+\mathrm{NO}_{3} \rightarrow \mathrm{NO}+\mathrm{NO}_{2}+\mathrm{O}_{2}$

$\mathrm{NO}_{2}+\mathrm{NO}_{3} \rightarrow \mathrm{N}_{2} \mathrm{O}_{5}$ *

$\mathrm{NO}_{2}+\mathrm{O} \rightarrow \mathrm{NO}+\mathrm{O}_{2}$

$\mathrm{NO}_{2}+\mathrm{O}+\mathrm{M} \rightarrow \mathrm{NO}_{3}+\mathrm{M}$

$\mathrm{NO}_{2}+\mathrm{O}_{3} \rightarrow \mathrm{NO}_{3}+\mathrm{O}_{2}$

$\mathrm{NO}_{2}+\mathrm{hv} \rightarrow \mathrm{NO}+\mathrm{O}$

$\mathrm{NO}_{3}+\mathrm{NO}_{3} \rightarrow 2 \mathrm{NO}_{2}+\mathrm{O}_{2}$

$\mathrm{NO}_{3}+\mathrm{hv} \rightarrow \mathrm{NO}_{2}+\mathrm{O}$

$\mathrm{NO}_{3}{ }^{*} \rightarrow \mathrm{NO}_{2}+\mathrm{O}$

$\left.\begin{array}{rl}\mathrm{N}_{2} \mathrm{O}+\mathrm{O}\left({ }^{1} \mathrm{D}\right) & \rightarrow \mathrm{N}_{2}+\mathrm{O}_{2} \\ & \rightarrow \mathrm{NO}+\mathrm{NO}\end{array}\right\}$

$\mathrm{N}_{2} \mathrm{O}+\mathrm{h \nu} \rightarrow \mathrm{N}_{2}+\mathrm{O}\left({ }^{1} \mathrm{D}\right)$

$\mathrm{N}_{2} \mathrm{O}_{5}+\mathrm{O} \rightarrow 2 \mathrm{NO}_{2}+\mathrm{O}$

$\mathrm{N}_{2} \mathrm{O}_{5}+\mathrm{M} \rightarrow \mathrm{NO}_{2}+\mathrm{NO}_{3}+\mathrm{M}$
Strat. $b, d$

$\pm 0.11$

a, d

fragmentary data

b

questionable data

d

$\pm 0.2$

h

$\pm 0.4$

d

c

$\pm 0.1$

b

$\pm 0.3$

$b, d$

$\pm 0.2(\mathrm{~T}=298 \mathrm{~K})$

a,d

b

$\pm 0.5$

$\pm 1$

c

$\pm 0.1$

d, a

*

upper limit only

$\pm 0.3$

d, c 
$\mathrm{N}_{2} \mathrm{O}_{5}+\mathrm{h} \nu \rightarrow$ ?

*

$\mathrm{N}_{2} \mathrm{O}_{5}{ }^{*} \rightarrow \mathrm{NO}_{2}+\mathrm{NO}_{3}$

$\mathrm{N}_{2} \mathrm{O}_{5}{ }^{*}+\mathrm{M} \rightleftarrows \mathrm{N}_{2} \mathrm{O}_{5}+\mathrm{M}$

$\mathrm{O}+\mathrm{O}+\mathrm{M} \rightarrow \mathrm{O}_{2}+\mathrm{M}$

$\mathrm{O}+\mathrm{O}_{2}+\mathrm{M} \rightarrow \mathrm{O}_{3}+\mathrm{M}$

$\mathrm{O}+\mathrm{O}_{3} \rightarrow 2 \mathrm{O}_{2}$

$O\left({ }^{1} D\right)+O_{2} \rightarrow O+O_{2}\left({ }^{1} \Sigma_{g}^{+}\right)$

$O\left({ }^{1} D\right)+O_{3} \rightarrow 20+O_{2}$

$O\left({ }^{1} D\right)+O_{3} \rightarrow 2 O_{2}$

$O\left({ }^{1} D\right)+M \rightarrow O+M$

$\mathrm{O}_{2}+\mathrm{hv} \rightarrow \mathrm{O}+\mathrm{O}$

$\mathrm{O}_{2}+\mathrm{M} \rightarrow \mathrm{O}+\mathrm{O}+\mathrm{M}$

$\mathrm{O}_{2}\left({ }^{\mathrm{I}} \Delta\right)+\mathrm{O}_{3} \rightarrow \mathrm{O}+2 \mathrm{O}_{2}$

$\mathrm{O}_{2}\left({ }^{1} \Delta\right)+\mathrm{M} \rightarrow \mathrm{O}_{2}+\mathrm{M}$

$\mathrm{O}_{2}\left({ }^{\mathrm{I}} \Sigma_{\mathrm{g}}^{+}\right)+\mathrm{O}_{3} \rightarrow \mathrm{O}+2 \mathrm{O}_{2}+\mathrm{M}$

$\mathrm{O}_{2}\left({ }^{1} \Sigma_{\mathrm{g}}^{+}\right)+\mathrm{M} \rightarrow \mathrm{O}_{2}+\mathrm{M}$

$\mathrm{O}_{3}+\mathrm{h} v \rightarrow \mathrm{O}+\mathrm{O}_{2}$

$*$

*

*

$*$

$*$ fragmentary data

b

$\pm 0.3$

f

$\pm 0.07$

c

$\pm 0.1$

a, c

$\pm 0.1$

d

$\pm 0.3$

d

\pm 0.1 (except $\mathrm{M}=\mathrm{O}_{3}$ )

d $\sigma, \phi$

b

$\pm 0.3$

f

$\pm 0.05$

$\pm 0.1 \quad\left(\mathrm{M}=\mathrm{O}_{2}\right)$
upper limit only $\left(\mathrm{M}=\mathrm{N}_{2}\right)$

$\pm 0.1$

a

$\sigma, \phi$

a 
Appendix. Conversion Tables

Equivalent Second order Rate Constants

Equivalent Third order Rate Constants

Conversion Factors for Units of Molecular Energy

Units of Optical Absorption Coefficients (Discussion)

Conversion Factors for Units of Optical Absorption Coefficients 


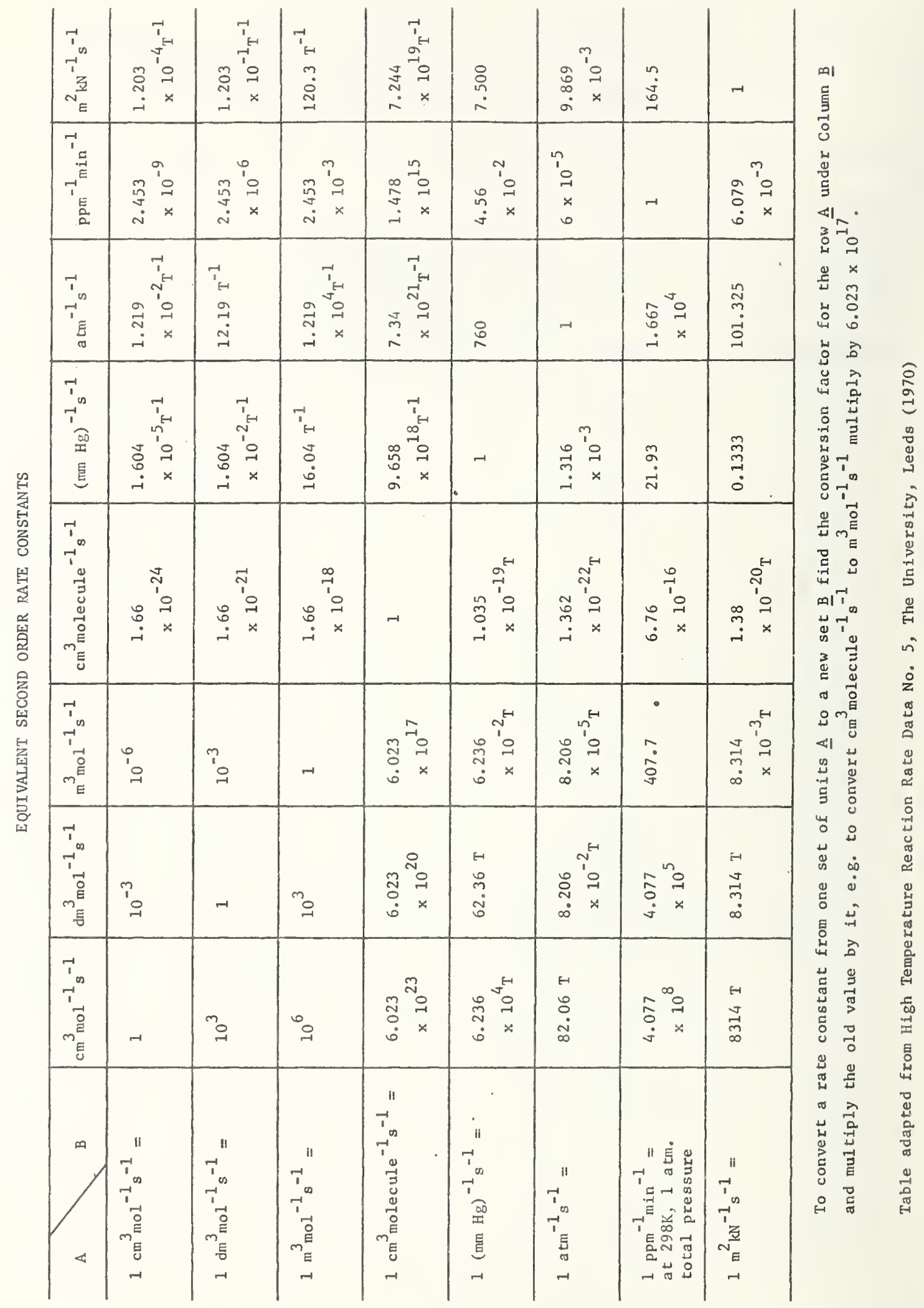




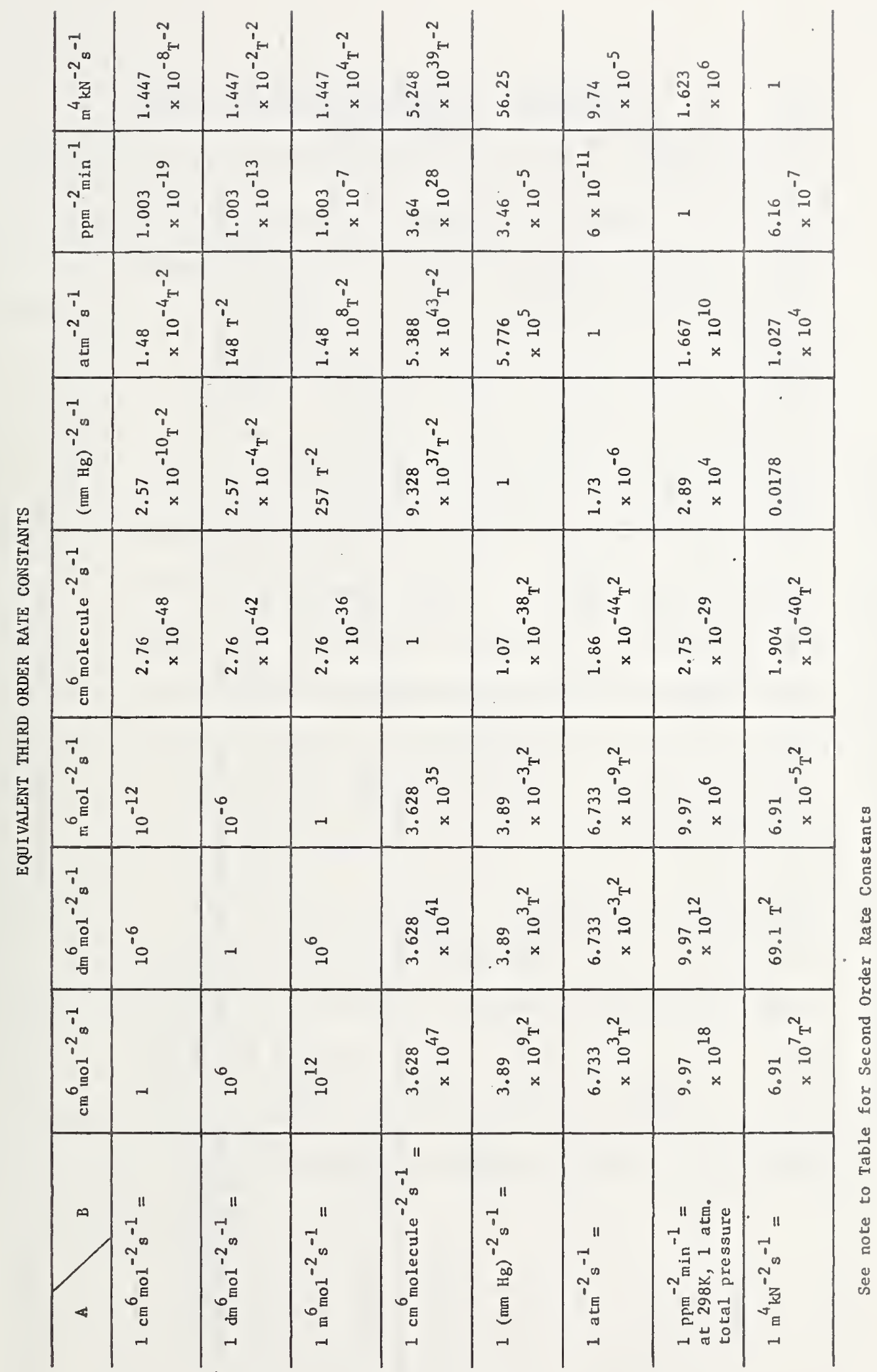




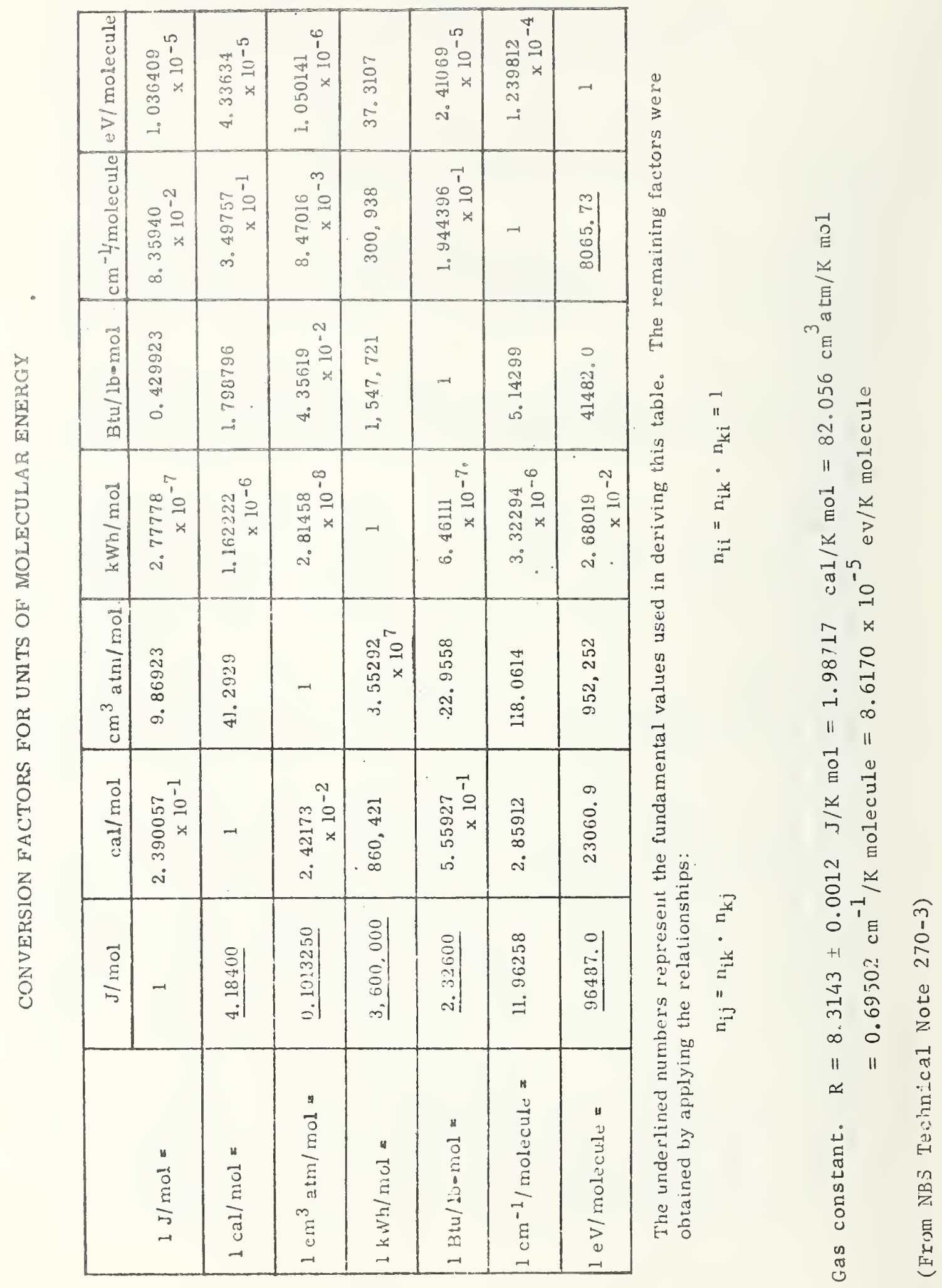




\section{UNITS OF OPTICAL ABSORPTION COEFFICIENTS}

The molar (linear) absorption coefficient $\epsilon$ is defined by the Lambert-Beer equation: $\epsilon=(1 / \ell c) \log _{10}\left(I_{0} / I_{t}\right)$ where $I_{0}$ and $I_{t}$ are incident and transmitted intensity, $l$ is the path length, and $c$ is the concentration ${ }^{*}$. The units for are (concentration ${ }^{-1}$ length $^{-1}$ ).

A variety of equivalent forms of this equation have been used to define reported values of $\varepsilon$. Both logarithmic bases $e$ and 10 have been used. Length has invariably been expressed in $\mathrm{cm}$. Concentration has usually been expressed in (mo1/1iter). Often a pressure unit has been used instead of a concentration unit, in which case the temperature to which the value of the pressure is referred must be specified. When pressure units are used the absorption coefficient is usually denoted by $k($ or $\alpha)$ with units of $\left[(\text { pressure }(T))^{-1}\right.$ (length) $\left.^{-1}\right]$. When the pressure unit used is ( 1 atmosphere at $273 \mathrm{~K}$ ), the value of $k$ is expressed in any of the numerically equivalent forms: [atm at $\left.273 \mathrm{~K}^{-1} \mathrm{~cm}^{-1}\right] ;\left[(\mathrm{NTP})^{-1}\right.$ $\mathrm{cm}^{-1}$ ]; or $\mathrm{cm}^{-1}$. This last form is equivalent to converting the measured value of $l$ at $T$ and $P$ to its corresponding value $l_{0}$ at the reference state $T_{0}=273 \mathrm{~K}$ and $P_{0}=1$ atm $\left.\left(\ell_{0}=\ell \times\left(P / P_{0}\right) \times T_{0} / T\right)\right)$ and using the eqn: $k=\left(1 / l_{0}\right) \log \left(I_{o} / I_{t}\right)$.

Alternatively the molecular concentration, $n$, expressed in (molecules/ $\mathrm{cm}^{3}$ ) may be used. Then the molecular "cross-section", $\sigma$, is defined as $\sigma=(1 / \mathrm{n} l) \log _{\mathrm{e}}\left(I_{\mathrm{o}} / \mathrm{I}_{\mathrm{t}}\right)$ 
Because of the diversity of units, when using reported values in numerical calculations one must always determine what defining equation was used. When reporting absorption coefficients it is recommended that the units be given explicitly and that the defining equation appear in table and figure captions.

A table of conversion factors is attached.

* Commission on Symbols, Terminology, and Units, I.U.P.A.C., M. L. McGlashan chairman, Pure and Applied Chemistry, 21, 1 (1970). 


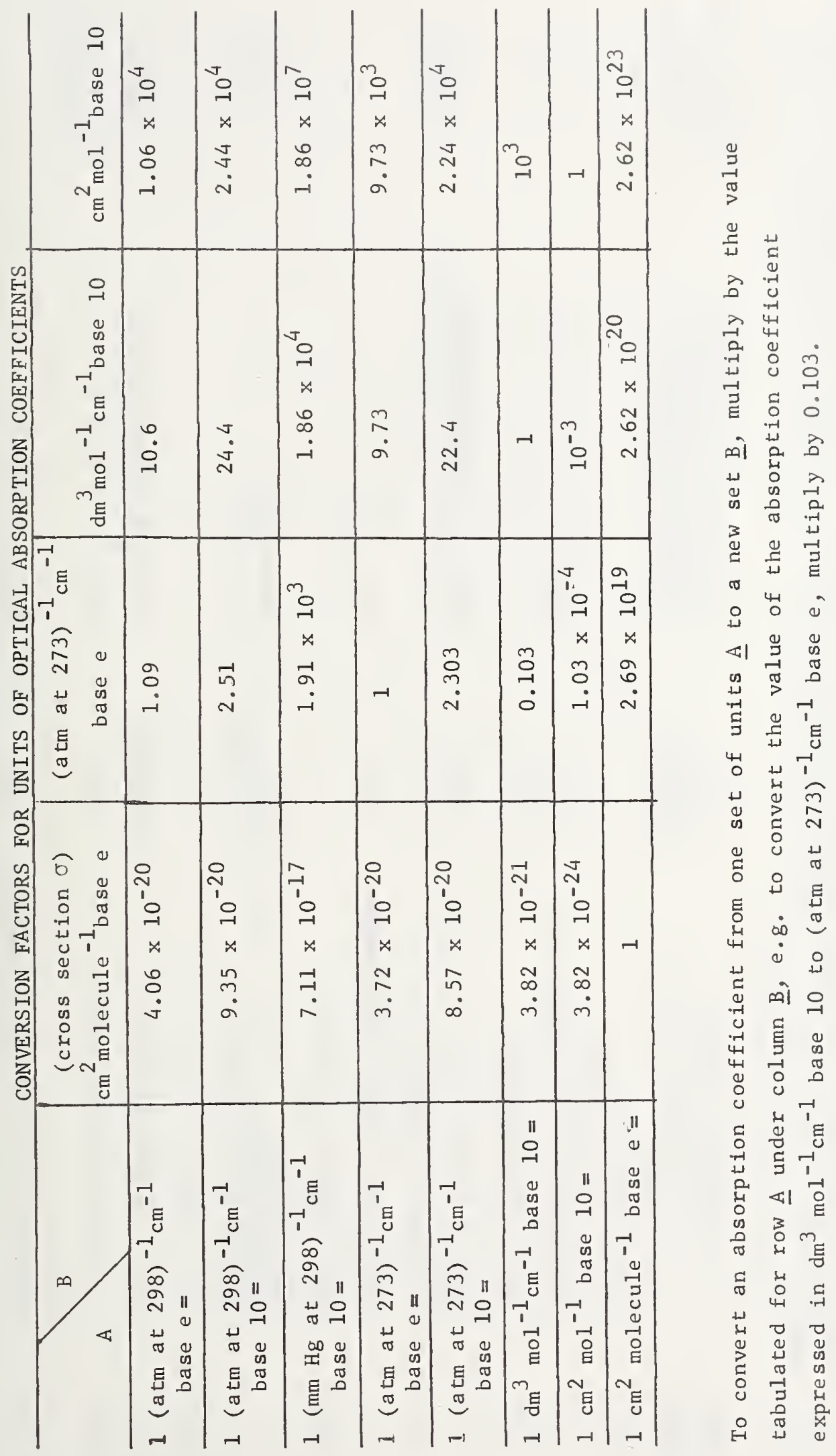




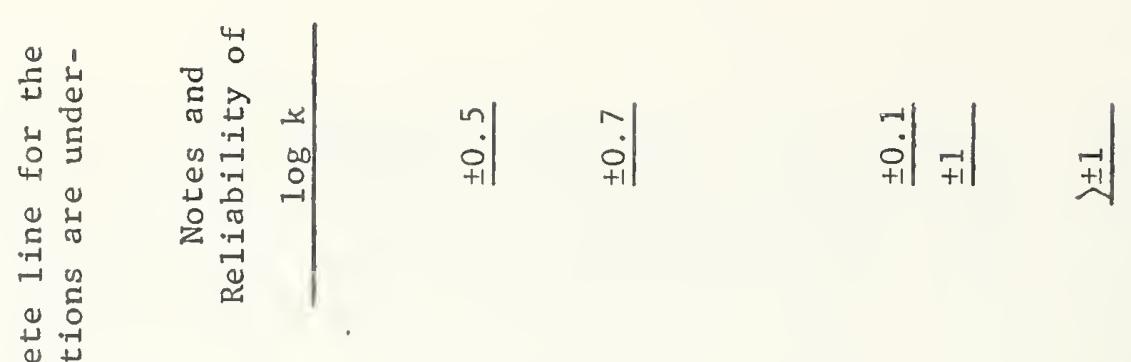

(1) +1

है

(1)
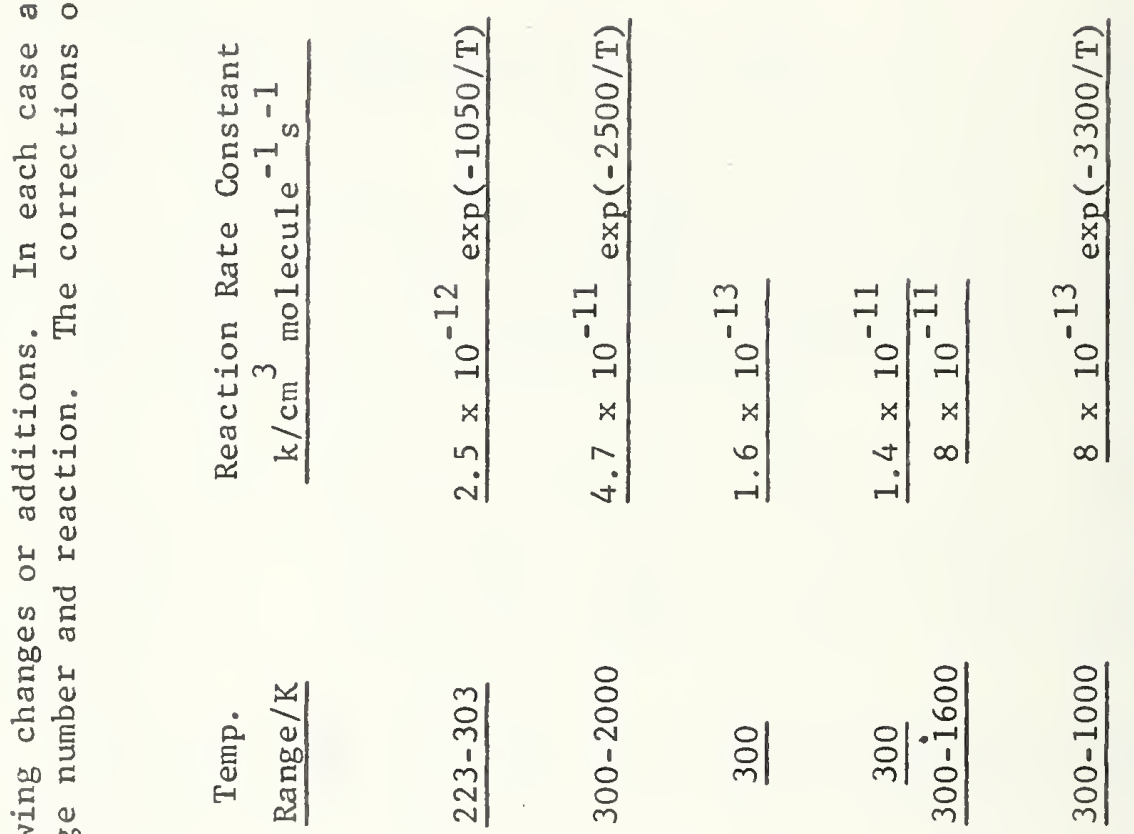

म4

is

i $\quad$ क 5

足 4

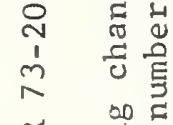

ก ณ

ก ल

글

Эู

N $\stackrel{0}{0} \stackrel{0}{\square}$

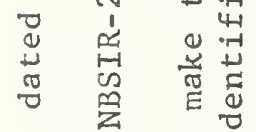

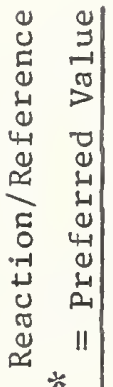

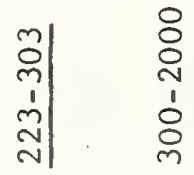

잉

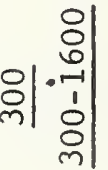

8
8
0
1
0
0
m|

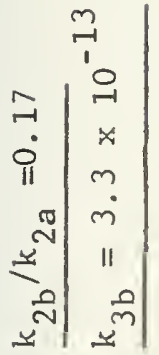

용

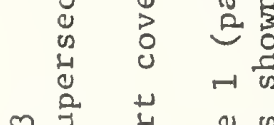

유

$1<$ क ते

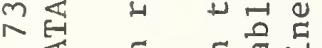

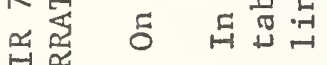

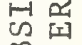

ฉ

วิ

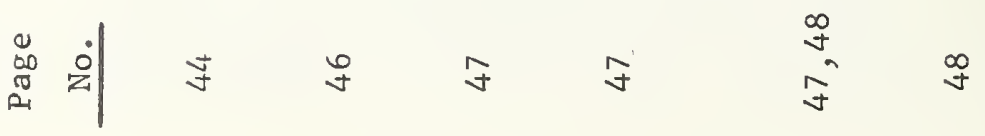




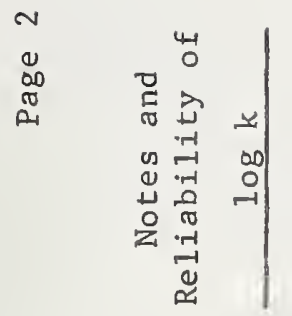

峁

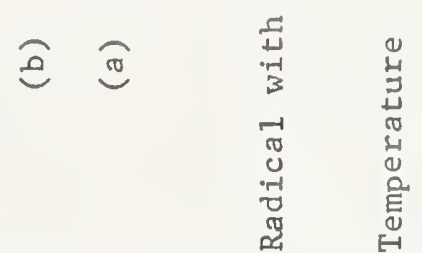

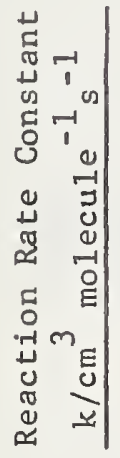
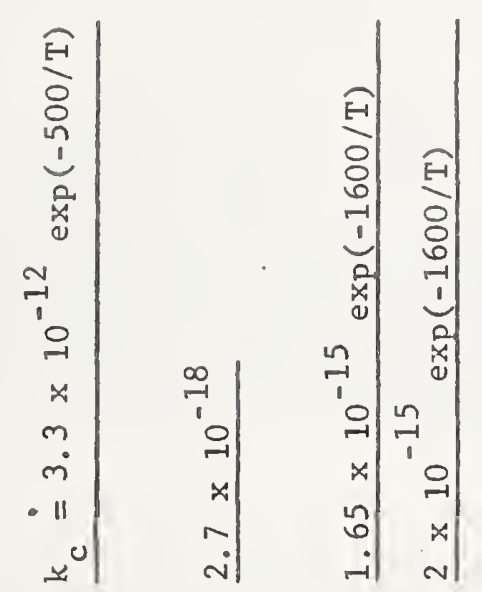

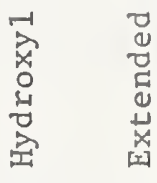

世

$\begin{array}{cc}0 \\ 0 \\ 0 \\ -1 & 0 \\ 0 & 0\end{array}$

离 曹

感

แ⿰㇒⿻二丨冂

곰뒁 명

4.

욤

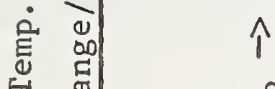

m

응<smiles>[O-][Os]</smiles>

政 +

u ूँ

出

हू नू क क

यु न यु

பّ

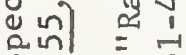

क : ᄋ

is 0 i

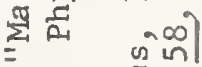

ब

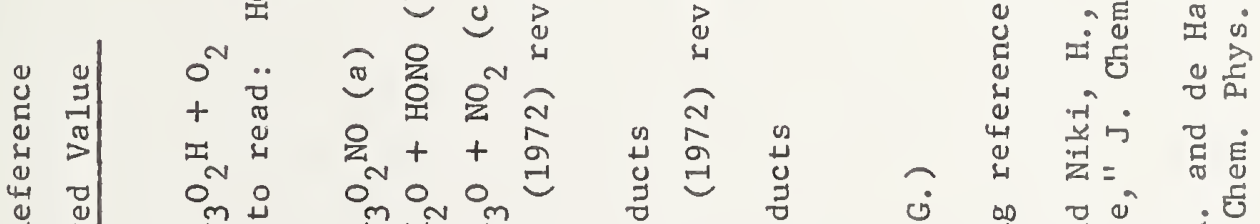

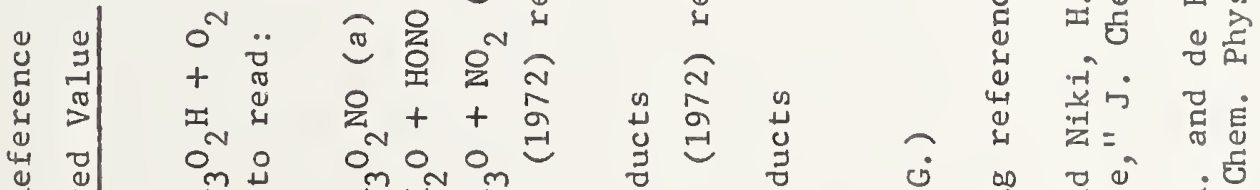

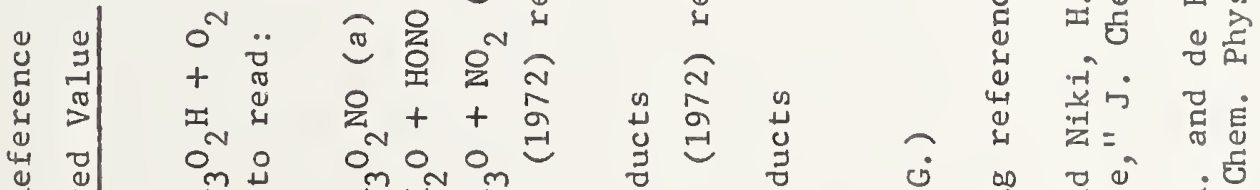

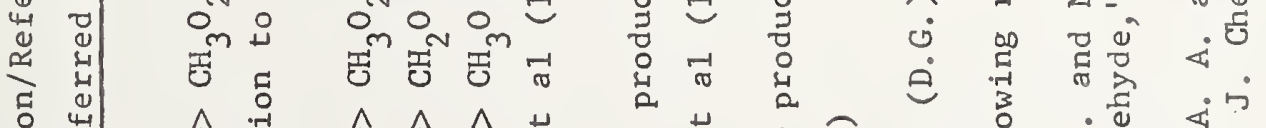

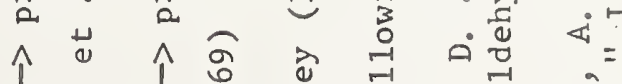

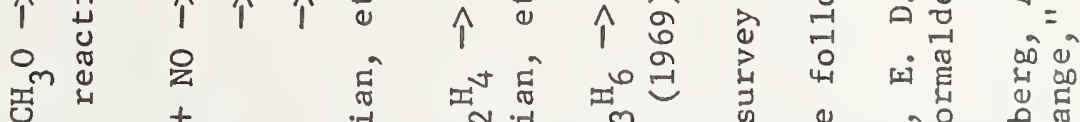

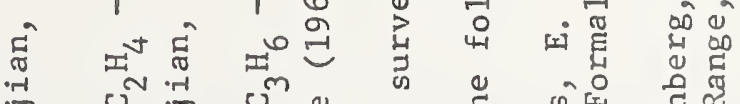

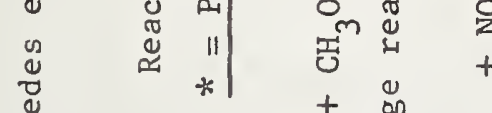

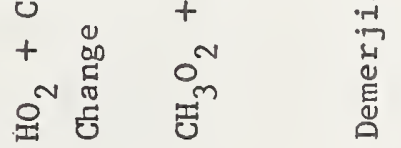

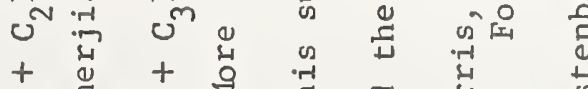

范

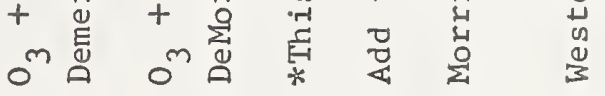

กิ 今ั

ก่

舟

约踏

完

0
$\infty$
0
0
0

a

ㅇํ हn

요 
ERRATA-NBSIR 73-206, second printing

page 13 Reaction Mechanism, 5th line: delete and № 2

page 17 Table III:

Heading for columns D, E, F, G, H and I should read:

Absolute rate constants, $\mathrm{k} / 10^{-10} \mathrm{~cm}^{3}$ molecule $\mathrm{e}^{-1} \mathrm{~s}^{-1}$

page 38 Table I:

1) The values given for $\epsilon(T \leqq 300 \mathrm{~K})$ for $\lambda=230$, $240,250,260$, and $270 \mathrm{~nm}$ are in units of $10^{5} \mathrm{~cm}^{2} / \mathrm{mol}$

2) The value of $\epsilon(T=1100 \mathrm{~K})$ at $\lambda=260 \mathrm{~nm}$ should be $1.9 \times 10^{5} \mathrm{~cm}^{2} / \mathrm{mol}$

Ju1y 24, 1973 
FOFM NBS-1 I4A $11-711$

U.S. UFPT, OF COMM.
BIBLIOGRAPHIC DATA
SHEET
1. PUBLICATION OR RETORTNO.

$\therefore \quad$ 2. Govthiccessicia

4. THTLE AND SUBTITLE NBSIR $73-207$

Chemical. Kinetics Data Survey

VI. Photochemical. and Rate Data for Twelve Gas Phase Reactions of Interest for Atmospheric Chemistry

\begin{tabular}{|l} 
7. AUTHOR(S) Robert $F$. Hampson \\
9. PERFORMING ORGINITATION NAME AND ADDRESS \\
NATIONAL BUREAU OF STANDARDS \\
DEPARTAENT OF COMMERC \\
WASHINGTON, D.C. 20234 \\
\end{tabular}

12. Sponscririg Organization, Name and Address Department of pransportation Washingtor , D. C. 20590

Nationa1 Bureau of Standards Wastingtorl, D. C. 20234

15. SUPPLESENTALY NOTES

16. ABSTRACT (A 200. wand or less factual summary of most significant information. If document inc!udes a significant bibliography or lilcratre survey, mention it here.)

Department of Navy

Naval Ordnance Systems Command

Washington, D. C. 20360
5. Publication I)ate

August 1973

6. Performing Ceqanizat an Cude

8. Petformine Organization

NBSIR $73-207$

10. Project lask: Work L rit 3 .

31604093160520

11. Contract/Grant vo.

13. Type of Refort \& Period Covered

Interim

14. Sponsoring igency Code

Photochemical and race data have been evaluated for twelve gas phace reactions of interest for the chenistry of the stratosphere. The results are presented in sita shects, one for each reaction. For each reaction the data are sumnarizad. A preferred value is given for the rate constant or the primary quantum yield and photoabsorption cross section.

17. KEY WORDS (Alphabetical order, separated by semicolons) Atmospheric chemistry; chemical kinetics; data evaluation; gas phase reaction; optical absorption cross section; photochemistry; guantum yield; rate constants.

18. AVAILABILITY STATEMENT

$[\mathrm{X}]$ UNL.MMTED.

[]FOR OFIICIAI. DIST RIBUTION. DO NOT RELEASE TO NTIS.

\begin{tabular}{|l|c|}
$\begin{array}{c}\text { 19. SECURITY CLASS } \\
\text { (THIS REPORT) } \\
\text { UNCL ASSIFIED }\end{array}$ & 124 \\
\hline $\begin{array}{l}\text { 20. SECURITY CLASS } \\
\text { (THIS PAGE) } \\
\text { UNCL ASSIFIED }\end{array}$ & 22. PriCe \\
\hline
\end{tabular}



(1)

a d

$\therefore+$

$\therefore \because$ 